\title{
39. EVOLUTION AND SEDIMENTARY HISTORY OF THE CAPE BOJADOR CONTINENTAL MARGIN, NORTHWESTERN AFRICA
}

\author{
Michael A. Arthur, ${ }^{1}$ Ulrich von Rad, ${ }^{2}$ Chris Cornford,${ }^{3}$ Floyd W. McCoy, ${ }^{4}$ and Michael Sarnthein ${ }^{5}$
}

\begin{abstract}
The Cape Bojador region of the northwestern African continental margin is apparently an unusual passive margin setting. Climatic fluctuations, local volcanism, and possibly tectonics have played important roles in the sedimentary record in this region. A transect of drilling sites connected by seismic profiles is available from the coastal Aaiun Basin (CORC 15-1), across the shelf (Spansah 51A-1), on the continental slope (DSDP Site 369), the upper continental rise (DSDP Site 397), farther out on the rise (e.g., DSDP Sites 139 and 140), and the abyssal plain (DSDP Sites 137 and 138). These data allow construction of a profile perpendicular to the margin, and reconstruction of the sedimentary evolution there.

Lower Cretaceous sediment (Hauterivian) is the oldest recovered in a DSDP site along this part of the margin. Equivalent sediment was recovered from hydrocarbon exploration wells in the Aaiun Basin. Subsidence rates under the present shelf, slope, and upper rise were rapid during the Jurassic and Early Cretaceous (110 to $140 \mathrm{~m} / \mathrm{m} . \mathrm{y}$.), and diminished since the Late Cretaceous (average $13 \mathrm{~m} / \mathrm{m} . y$.$) . A sequence of Lower Cretaceous Wealden-type deltaic and prodeltaic en-$ vironments has been delineated from well and outcrop data: a thick sequence of sandstone and siltstone (Spansah 51A-1) grades seaward to laminated prodelta muds containing thin siderite layers (DSDP Site 397). Deltaic sedimentation gradually wanes in the Middle Cretaceous in the coastal basin. This interval is represented by a hiatus at Site 397. A Middle to Late Cretaceous transgression resulted in deposition of more pelagic black shale, nannofossil marl, chert, and limestone on the Cape Bojador slope (DSDP Site 369) and in the Aaiun Basin.

The 1-2.5-km thick Hauterivian to Oligocene record at Site 397 is missing due to one or more superimposed erosional events (intensified bottom currents, slumping) which may correlate with hiatuses on the slope and shelf and in deeper sites. These hiatuses seem to occur during regressive episodes (especially during latest Eocene to Oligocene times) and with concomitant climatic changes. Without well control, it is impossible to correlate the major seismic reflectors, some of which represent hiatuses, between the continental rise and slope. The upper continental rise and lower slope receded during the Paleogene and into the early Miocene by cutting of submarine canyons, slumping, and erosion by bottom currents. A thick sequence of slumps, pebbly mudstones, and other redeposited sediment accumulated at the base-of-slope on the upper rise during the early to middle Miocene. Much of the material was derived from contemporaneous slope sediment with some admixed shelf components. High organic contents in the redeposited sediment have led to generation of biogenic methane and give the sediment a good petroleumgenerating potential under a geothermal gradient of about $46^{\circ} \mathrm{C} / \mathrm{km}$. Both marine and terrestrial organic materials are preserved in varying proportions.

An imprint of Canary Island volcanism is seen in DSDP Sites 369 and 397 in the form of rhyolitic ash layers within Neogene sediment, especially during the middle Miocene to Pliocene at Site 397. Several thick volcaniclastic conglomeratic sands were deposited from debris flows on the upper rise during the middle Miocene (17.5 to 15.5 m.y.B.P.). These may have been derived from Fuerteventura in the Canary Islands during an early submarine to subaerial shield-building phase.

Neogene sedimentation rates are fairly high across the margin. Nannofossil marls and oozes are the primary sediment type. Very little redeposition of sediment has occurred since the late Miocene in the Cape Bojador region. Fluctuations in fertility and terrigenous-volcanic input of sediment representing alternation of humid and arid conditions offshore of this presently arid region are recorded in upper Miocene through Quaternary sediments due to short-term climatic variations.

The Mesozoic evolution of the uniformly subsiding, 12-15-km-thick "Cape Bojador margin basin" can be compared with the history of the contingent eastern North American margin (Baltimore Canyon Trough to Newfoundland Shelf Basin), whereas the Neogene history shows marked differences due to regional abnormalities at the northwest African margin.
\end{abstract}

\footnotetext{
${ }^{1}$ Scripps Institution of Oceanography, Deep Sea Drilling Project, A-031, La Jolla, California.

${ }^{2}$ Bundesanstalt für Geowissenschaften und Rohstoffe (BGR) Postfach 510153 D-3 Hanover-53, Federal Republic of Germany.

${ }^{3}$ Programmgruppe für Erdol und Organische Geochemie, D5170 Jülich, Federal Republic of Germany.

${ }^{4}$ Lamont-Doherty Geological Observatory, Columbia University, Palisades, New York.

${ }^{5}$ Geologisch-Paläontologisches Institut der Universität, Universităt Kiel, D-23 Kiel, Federal Republic of Germany.
} 


\section{INTRODUCTION (M.A.A.)}

\section{Statement of Purpose}

The drilling of Holes 397 and 397A during Leg 47A on the upper continental rise off northwestern Africa (Figures 1 and 2) in 2900 meters of water revealed a 1300-meter-thick expanded sequence of Neogene rise sediments overlying Hauterivian dark, laminated mudstones alternating with siderite layers. The lower 600 meters of the Neogene section recovered at this site consists of sediment emplaced by subaqueous gravity flows (slides, slumps, debris flows, turbidity currents, and turbid layer transport). Slump masses and pebbly mud- stones/conglomerates predominate, but an overall evolutionary sequence from slumps and debris flows through turbiditic mudstones and sandstones into hemipelagic drape can be followed in vertical section. The juxtaposition and intercalation of a number of lithotypes derived from several sources, the variety of sedimentation processes, and continuous coring with excellent recovery in a passive margin setting make this "flyschoid section" an important sequence to describe and interpret.

The coring of a complete sequence on the uppermost continental rise has been correlated with information from another site on the mid-slope (Site 369, Leg 41),

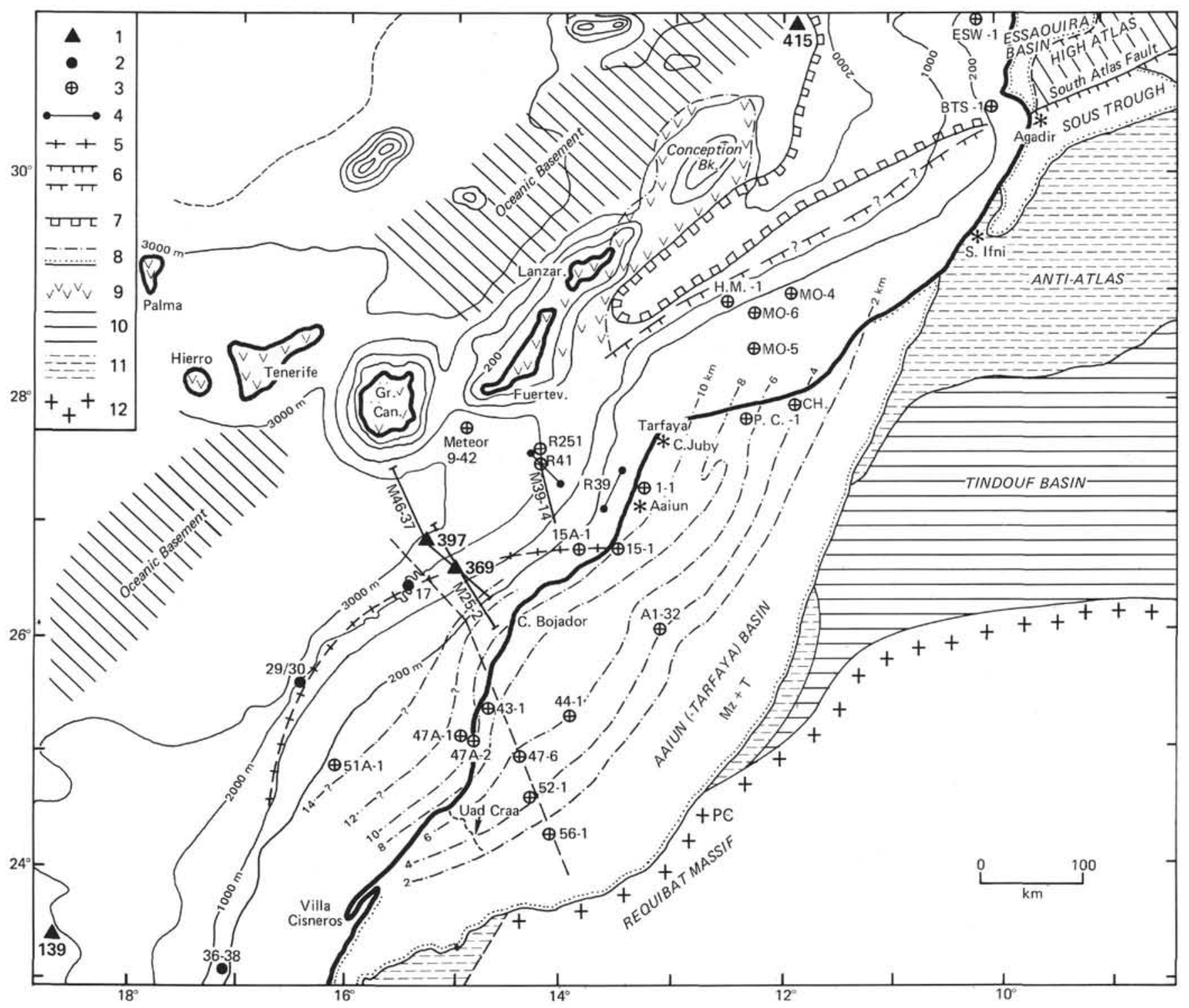

Figure 1. Sketch map of the Cape Bojador continental margin between the Aaiun-Tarfaya coastal basin and the Canary Islands and its vicinity. $1=$ DSDP sites; 2 = selected "Valdivia" dredge and core stations (von Rad et al., 1978); $3=$ selected onshore and offshore commercial wells; $4=$ seismic refraction profiles (Roeser et al., 1971); $5=$ axis of "slope anticline" (Hinz et al., 1974); 6 = major fault; 7 = limit of offshore "salt basin" (modified from Beck and Lehner, 1974); $8=$ Mesozoic-Cenozoic coastal basins with approximate isopachs in $\mathrm{km} ; 9=$ Cenozoic volcanics; $10=$ unfolded Paleozoic (Tindouf Basin); 11 = late Precambrian and Paleozoic rocks folded during Hercynian orogenesis (Mauretanides); $12=$ Precambrian crystalline massif. 


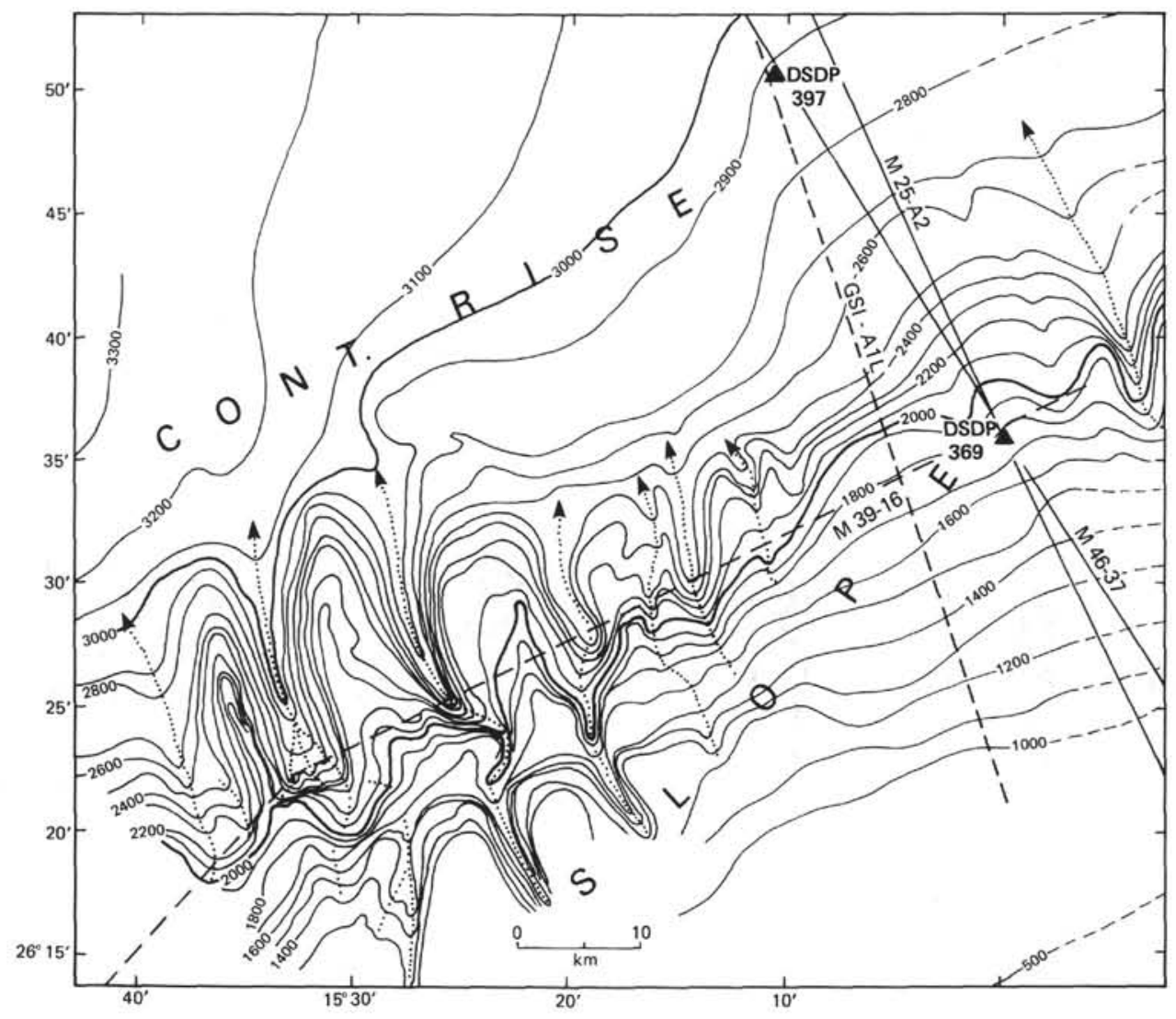

Figure 2. Location map of Sites 397 and 369. Bathymetry (contours in m) modified after von Rad et al. (1978); DSDP sites, seismic lines and locations of major canyon areas shown.

the large amount of available seismic information (e.g., Hinz et al., 1974; Hinz; Wissmann; both, this volume), dredges and piston cores from canyons and slopes (e.g., von Rad et al., 1978), and geological studies and commercial well logs from the adjoining coastal basin and shelf (Aaiun Basin; e.g., Querol, 1966; AUXINI, 1969; Spansah well, CONOCO, 1969; Ratschiller, 1970; Einsele and Wiedmann, 1975). Altogether, these data provide information for a comprehensive interpretation of the geologic history of this section of the northwestern African continental margin during the Mesozoic and Cenozoic from the coastal basin down to the continental rise (Figures 3 and 4 ).

Studies of core material have provided information on the evolution of climate and its influence on sedimentation on the source environment of the adjacent arid continent, the Cape Bojador shelf and slope, and along the deeper continental margin (Cita and Ryan; Shackleton and Cita; Mazzei et al.; Lutze et al.; Diester-Haass; all, this volume). Both local and global climatic changes and related oceanographic variations have profoundly affected sedimentation, fossil preservation, and organic carbon content.

The proximity of the Canary Islands volcanic chain to Site $\mathbf{3 9 7}$ has also left a pronounced imprint on the sedimentary record in the form of abundant ash layers and volcaniclastic sandstones and conglomerates (e.g., see Schmincke and von Rad; Lopatin; both, this volume). This adds an additional complexity to the record on the upper continental rise which shows sedimentary sources from numerous directions and deposition by various processes.

In addition, the interpretation of geological events, margin structures, and organic geochemical studies (for review see Cornford; Whelan; both, this volume) provides a unique opportunity to evaluate the diagenesis of organic matter and the hydrocarbon potential in this passive continental margin setting.

In this paper, we attempt a tentative synthesis of this information and provide a description of the overall evolution of this mature passive continental margin.

\section{General Setting}

Holes 397 and 397A of Leg 47A were drilled in about 2900 meters of water on the upper continental rise of northwestern Africa west of Cape Bojador (Figure 1). A total of 1453 meters of sediment was penetrated with good core recovery (average: $60 \%$ ). The site is located only $32 \mathrm{~km}$ downslope from Site 369 of Leg 41 (1752 m water depth; Lancelot, Siebold, et al., 1978) just on the southeastern border of the narrow Neogene basin formed between the Canary Island Archipelago and the southwest-trending northwestern African continental margin ("South Canary Island Channel"). The sedi- 


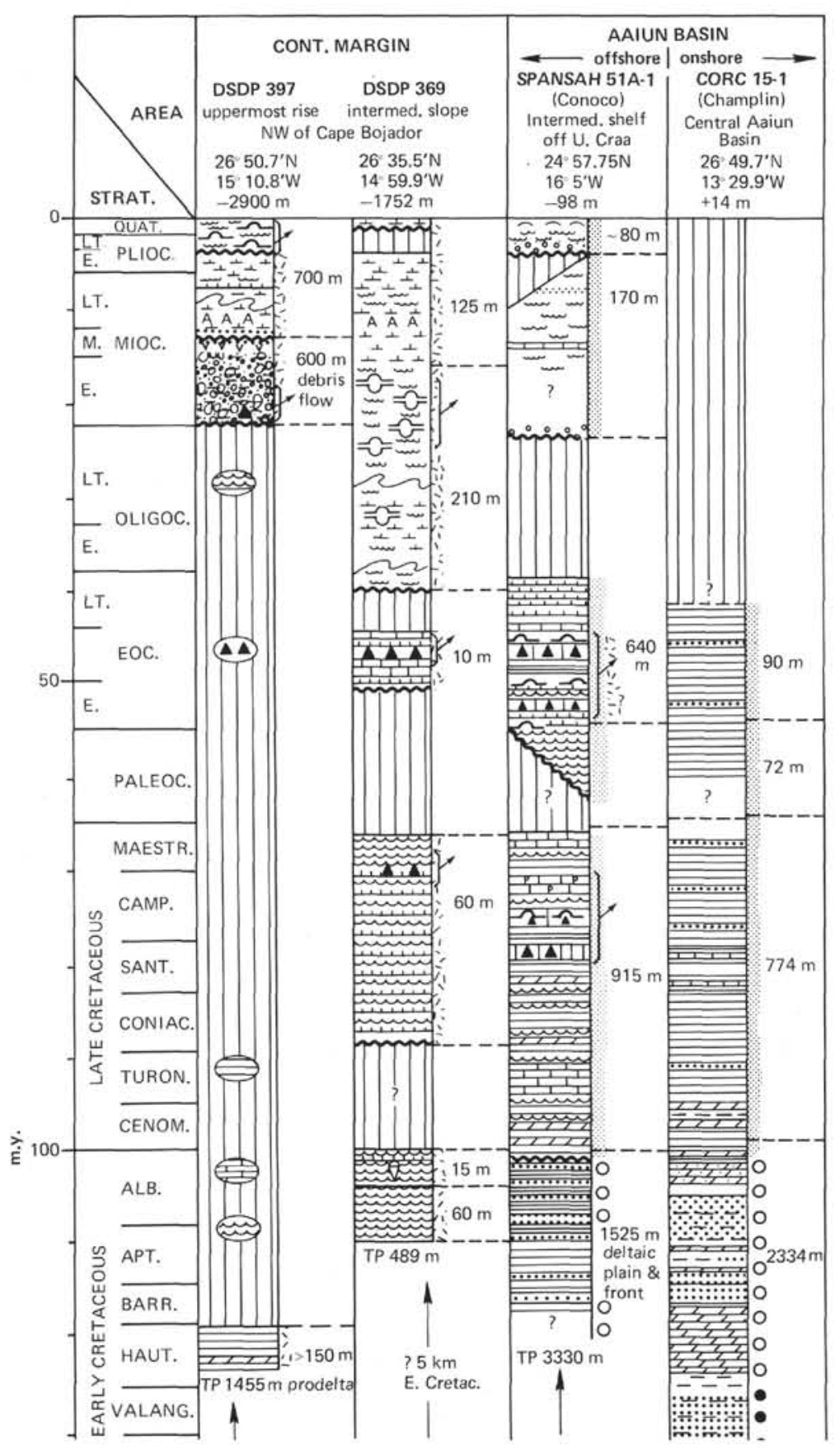




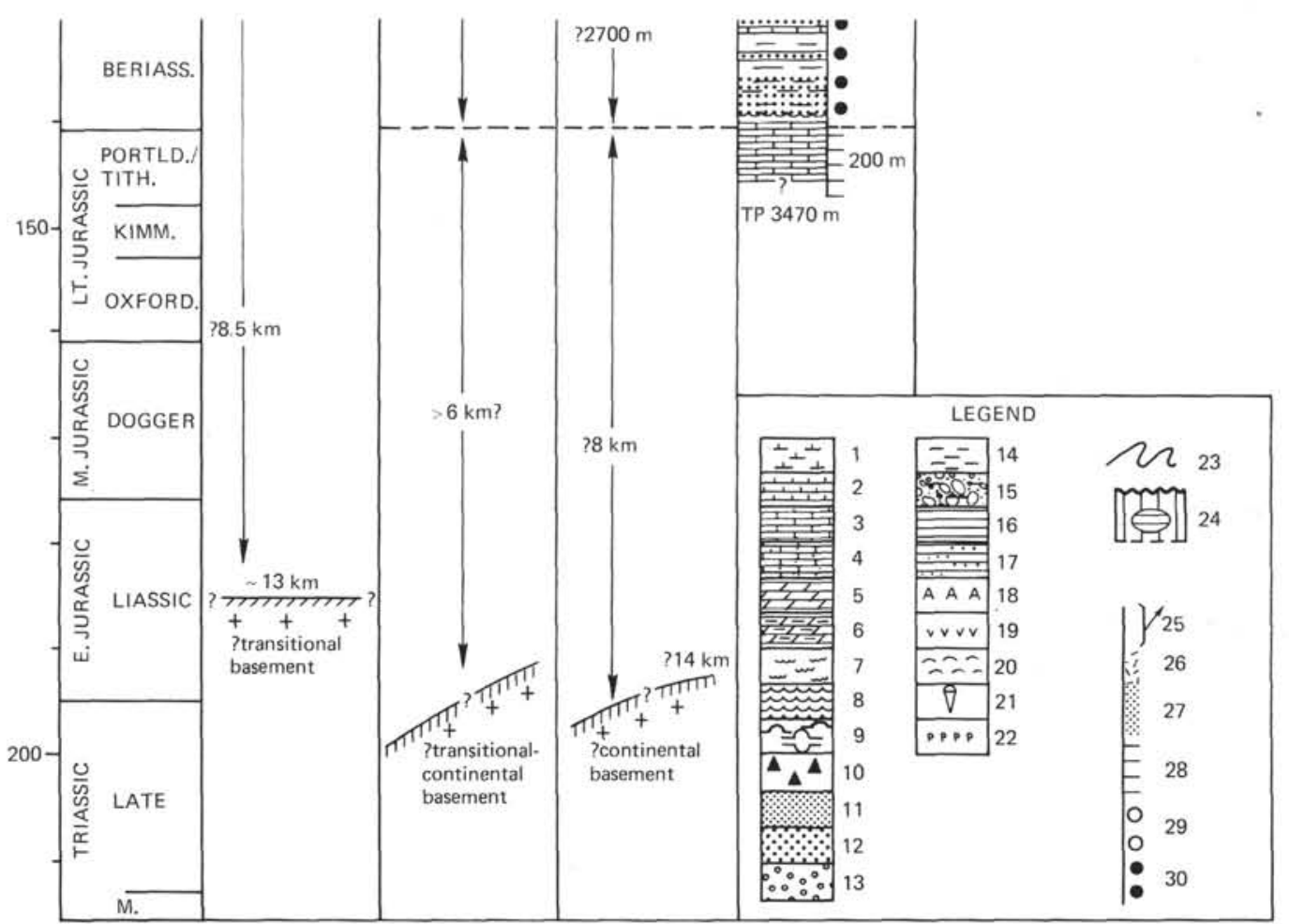

Figure 3. Highly generalized Mesozoic and Cenozoic stratigraphy of four drill holes across the Cape Bojador continental margin (modified from von Rad and Einsele, in press): DSDP Sites 397 and 369, Spansah 51A-1 (shelf; CONOCO, 1969), CORC 15-1 (central Asiun Basin; AUXINI, 1969). 1 = nannofossil ooze; 2 = (nannofossil) chalk; 3 = limestone; $4=$ sandy limestone; $5=$ dolomite; $6=$ marly dolomite; $7=$ marl; $8=$ marlstone; $9=$ siliceous ooze/mud; 10 = porcelanite $(-$ chert) $; 11=$ silt(stone); $12=$ sand(stone) $; 13=$ conglomerate/gravel, 14 = clay/mud; $15=$ pebbly mudstone (debris flow deposit); $16=$ claystone; 17 = silty claystone; $18=$ ash layers; $19=$ volcaniclastic debris flows; $20=$ shell layers (coquina); 21 = belemnites; $22=$ phosphates/phosphorite; $23=$ slumping; $24=$ erosional unconformity with duration of hiatus and reworked lithologies; $25=$ upwelling conditions; 26-30 inferred environment of deposition: 26 = hemipelagic sediments (upper slope to upper rise); 27 = neritic, \pm clastic sediments (shelf; 28 = shallow-water (? platform) car bonates; 29 = paralic (lagoonal to intertidal); $30=$ terrestrial (alluvial plain, etc.). 

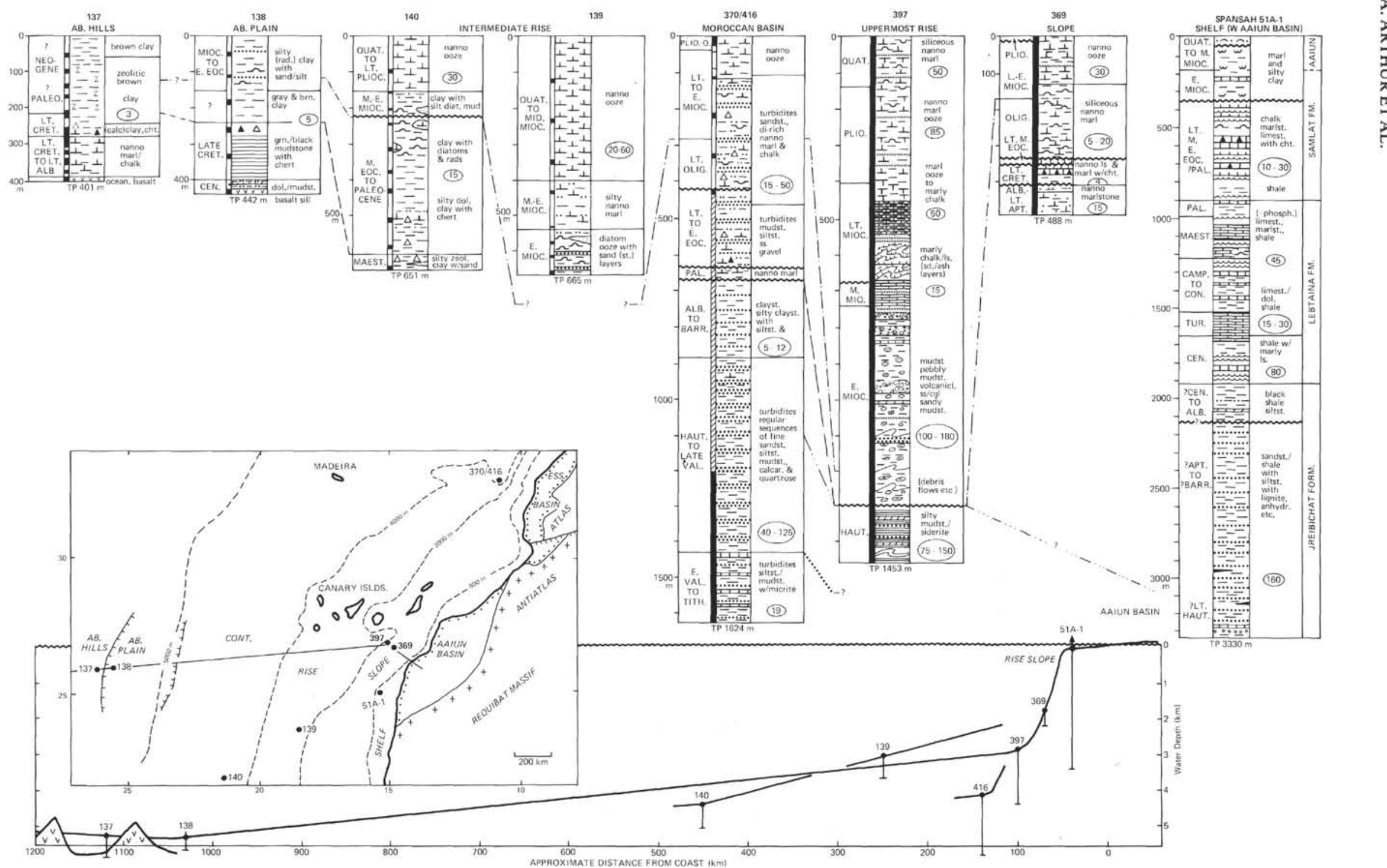

Figure 4. Generalized lithostratigraphy of DSDP sites across the northwestern African continental margin: Sites 137, 138, 139 (Leg 14) after Berger and von Rad (1972); Site 369 (Leg 31) after Lancelot, Seibold, et al. (1978); Site 416 (Leg 50) after Lancelot, Winterer, et al. (1977); Spansah 41A-1 after CONOCO (1969). Note different vertical scale for water depth and depth in hole and different depth scale for Spansah 51A-1. For explanation of symbols, see Figure 3. 
mentary section penetrated represents the seaward continuation of the onshore Aaiun Coastal Basin with maximum sediment thickness of 12 to $15 \mathrm{~km}$ ("Cape Bojador Marginal Basin," von Rad and Einsele, in press). Site 397 overlies probably transitional (to oceanic?) crust, possibly of Early Jurassic age (170 to 190 m.y. B.P.; see Hays and Rabinowitz, 1975).

A relatively narrow continental shelf of about $30 \mathrm{~km}$ width with a shelf break at 110 meters depth exists between Cape Juby and Cape Bojador, between which Site 397 is located on the upper continental rise. The shelf widens to nearly $100 \mathrm{~km}$ width to both the north and south (e.g., McMaster and LaChance, 1968). The continental slope off Cape Bojador is about $70 \mathrm{~km}$ wide and is deeply dissected by numerous submarine valleys and incisions (Seibold and Hinz, 1974; Rust and Weinecke, 1973; von Rad et al., 1978). However, Site 397 lies downslope of an inter-canyon position (Figure 2). The continental rise is $700 \mathrm{~km}$ wide, but the abyssal plains beyond the rise are not very extensive (Uchupi et al., 1976). Several DSDP sites were drilled in this province during Leg 14 (e.g., Sites 137 to 140; fig. 4; Berger and von Rad, 1972).

The onshore Aaiun Basin is one of a string of elongate coastal basins along the coast of western Africa (Lehner and DeRuiter, 1977). It is bounded on the north by the Precambrian Anti-Atlas Uplift-South Atlas Fault and the offshore salt basin northeast of the Canary Islands and on the south and east by the late Paleozoic fold belt of the Mauretanides and the Precambrian Requibat Massif (fig. 1). To the west, the basin is open to the sea. The occurrence of these coastal basins may be controlled by pre-existing basement structures (Kennedy, 1965) or their boundaries delineated by the interaction of continental margins with intersection of major oceanic fracture zones (Le Pichon et al., 1977; Uchupi et al., 1976). A thick section of Jurassic to Cretaceous, and a thinner section of Tertiary sediments fills the Aaiun Basin (Querol, 1966; Dillon and Sougy, 1974; AUXINI, 1969). The depocenter of the "Cape Bojador Marginal Basin" (i.e., Aaiun Basin plus its seaward continuation to the upper rise) is located beneath the present outer continental shelf and upper slope (von Rad and Einsele, in press; Figures 1 and 4 and Frontispiece). A pronounced anticlinal structure ("slope anticline') is present under the lower continental slope (Hinz et al., 1974). Landward of this structure, sedimentary strata dip slightly toward the Aaiun Basin.

The Canary Islands Archipelago with Gran Canaria, which is located about $100 \mathrm{~km}$ north of Site 397 , is a relatively recent feature of the northwestern African margin. Initial uplift and volcanism directly related to the evolution of this feature probably occurred during the early to middle Miocene (e.g., Dillon and Sougy, 1974; Schmincke, 1976; Abdel-Monem et al., 1974). Volcanism and subaerial exposure has continued through the Recent (see Figure 12).

\section{DESCRIPTION OF THE SEDIMENTARY SEQUENCE OF SITE 397 (F.W.M.)}

\section{Overview}

Within the 1453-meter sequence of sediments and sedimentary rocks drilled on the passive continental margin of northwestern Africa, five distinctive lithologic units were defined (see Figure 5 and Sediment Summary Chart 1 in back pocket). Generally, all units represent a section containing high proportions of terrigenous material and in one unit most of the material is allochthonous.

\section{Late Hauterivian Lithostratigraphic Unit 5}

At the base of the drilled section, a 156.3-meter-thick sequence of gray quartzose silty claystones was penetrated, designated as lithostratigraphic Unit 5. Interbedded within this unit are over 265 siderite layers (between 1 and $30 \mathrm{~mm}$ thick) in sharp contact with the adjacent mudstones. This sequence has been dated by calcareous nannoplankton as uppermost early to lower late Hauterivian (Early Cretaceous; Wind and Čepek, this volume). Mudstones contain up to 40 per cent of quartz with between 30 per cent and trace amounts of calcareous nannoplankton, traces of foraminifers, feldspar, pyrite, fish remains, and plant debris. Clay minerals can form up to 95 per cent of the sediment and are dominated by illite, with smaller proportions of kaolinite, chlorite, smectite, and mixed-layer phyllosilicates (Chamley and d'Argoud, this volume). Fish and plant debris, clastic grains, and pyrite are dominant in the coarse fraction. Some pelecypod fragments are found within calcareous mudstones. Small ammonites were only observed in three nannofossil marlstones (Wiedmann; Einsele and von Rad; both, this volume). Average carbonate values are less than 10 per cent, with locally high values in nannofossil marlstones up to about 60 per cent. Organic carbon content ( 0.5 to 0.9 per cent) appears to gradually increase downsection.

Lithostratigraphic Unit 5 contains evidence for both autochthonous and slightly displaced sediments. Within the upper portion of the unit, thin laminae $(0.25$ to 0.50 $\mathrm{cm}$ thick) form a varve-like sequence that is caused by slight textural and/or compositional variations (Einsele and von Rad, this volume). Burrow mottling is very rare, except in lower portions of this unit; where present, mottling does not disrupt fine laminae. Deformation suggesting some downslope "en masse" displacement is particularly evident in lowermost portions of lithologic Unit 5 as slump structures. Here, mudstones and siderite layers are intensely deformed with flow structures, faults, and boudinage-type features. The only distinct clastic layers occur higher in this unit (Core 397-39) where four very thin sandy silt layers are present, only one of which appears texturally graded. Silty mudstones in two cores (397A-39 and 397A-46) have small-scale cross-bedding. 


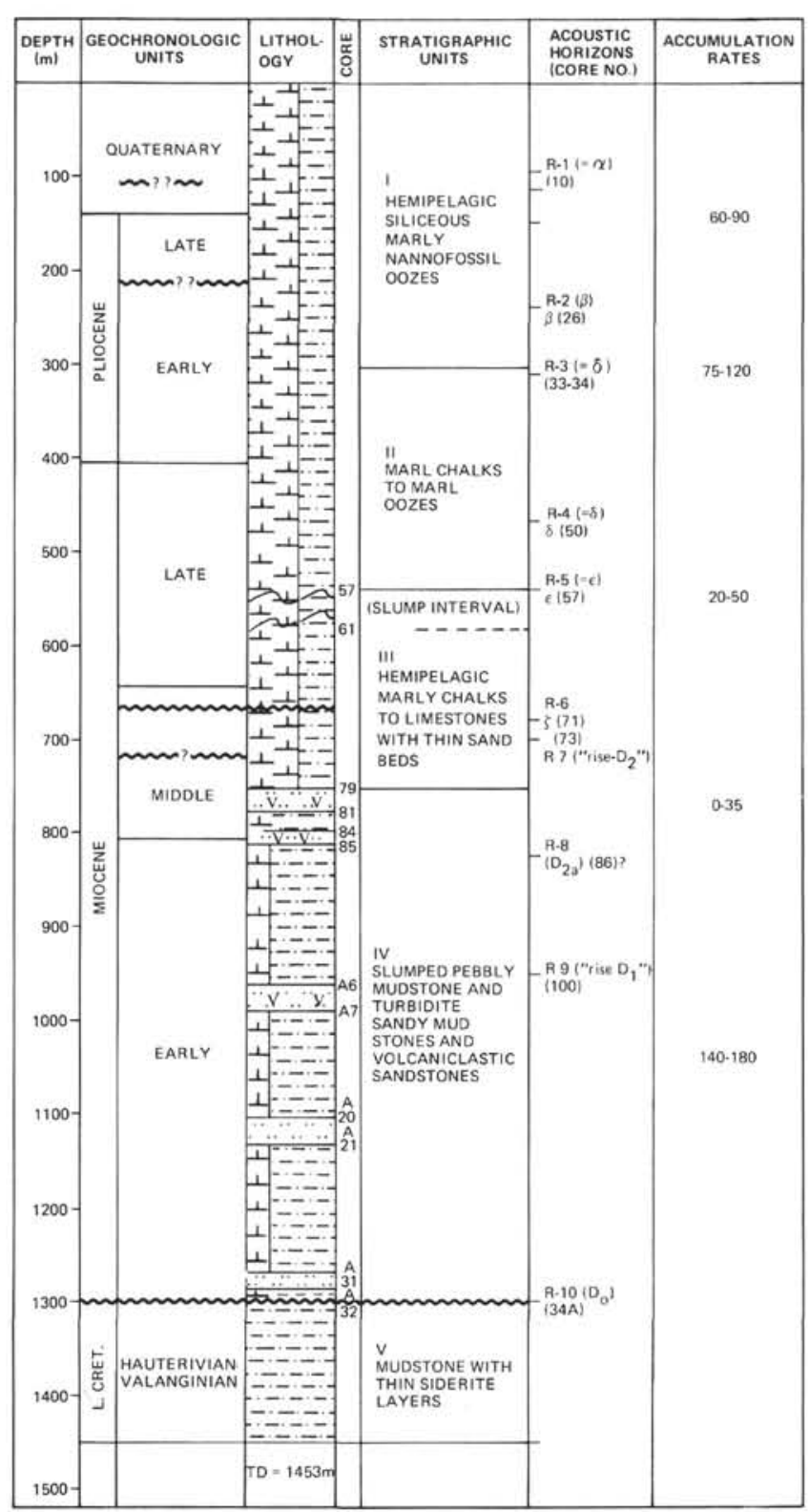

Figure 5. Graphic summary of Site 397 with lithostratigraphic and biostratigraphic units and acoustic horizons. Approximate accumulation rates $(\mathrm{m} / \mathrm{m} . \mathrm{y}$.) in brackets.

A pronounced unconformity representing a hiatus of over $100 \mathrm{~m} . \mathrm{y}$. separates lithologic Units 4 and 5.

\section{Lithostratigraphic Unit 4}

Unit 4 contains 544.5 meters of chaotic debris-flow deposits with slump features and soft-sediment deformational structures, often producing near-"migmatitic" textures (cf. plates in Arthur and von Rad, this volume). Pebbly mudstones form the dominant sediment type with interbedded conglomerates, marly limestones, as well as volcaniclastic sandstones and conglomerates. The unit is dated as middle to early Miocene, with reworked late Oligocene sediments (NP 24, P.21) incorporated into slump folds near the base of the unit.
Because of the allochthonous nature of this sequence, both smear-slide and coarse-fraction analyses indicate a high variability in sedimentary components. Much displaced calcareous debris is evidently transported from shallower water areas, with a significant amount of stained quartz grains and some plant debris (see Site 397 Report, cf. Sarnthein). Radiolarians and diatoms (transformed into opal-CT; see Riech, this volume) are present in minor amounts in the lower half of the unit; the upper half of the unit contains volcanic material. The clay mineral assemblage is surprisingly uniform, dominated by smectites, with minor proportions of kaolinite, mixed-layer clays, illite, and chlorite (Chamley and d'Argoud, this volume). Carbonate content ranges from 70 per cent to less than 10 per cent, generally increasing upsection. Organic carbon values fluctuate with higher values up to nearly 4 per cent, particularly within the pebbly mudstone sequence. Textural parameters are similarly variable reflecting the allochthonous nature of this sequence.

Clasts within the pebbly mudstones are granules and small pebbles of quartz, quartzite, mudstone, limestone, and marly nannofossil chalk. Plastic deformation of these clasts increases markedly towards the lower central portion of this unit, where the clasts are often deformed along shear planes as well as within slump folds. More resistant clasts of harder rock types such as quartzite have produced textures suggesting slow movement with frozen trails of finer detritus in their lee. Numerous intercalated mudstones and marly limestones may mark shear zones of movement or intervening zones of (hemi)pelagic sedimentation, as would be suggested in some instances by the presence of burrows.

Numerous sand and silt layers occur throughout Unit 4. Altogether, about 80 sand layers were noted, 32 of which ( 40 per cent) show evidence of textural grading. Graded units seem to be more prevalent immediately above those areas where clasts within the pebbly mudstones have been strongly deformed by plastic flowage. Non-graded layers are predominantly below or somewhat above these areas of maximum deformation; they could represent redeposited material from upslope or current-winnowed deposits. Within the uppermost part of the unit, there is an 8-cm-thick layer of alternating dark and light cross-bedded sands ("climbing ripple" type) suggesting strong current activity. The black sands are reworked volcanic sediments containing up to 60 per cent glass shards.

Four volcaniclastic sandstones in the upper portion of this lithologic unit have been informally designated as $V_{1} . V_{2}, V_{3}$, and $V_{4}$. The uppermost conglomate sandstone, $V_{1}$, is texturally graded near its base. The lower volcaniclastic debris flows, $V_{3}$ and $V_{4}$, are massive hyaloclastites (see Site 397 Report). For a detailed description and interpretation of this volcanic material, see Schmincke and von Rad (this volume).

Apparent stratigraphic dips of $25^{\circ}$ occur in a marly limestone underlying volcaniclastic Unit $\mathrm{V}_{3}$. Variations between $5^{\circ}$ and $40^{\circ}$ were recorded further downsection (between Cores 397A-10 and 397A-14), with an average of about $20^{\circ}$. Near the base of lithologic Unit 4 (Cores 
397 A-26 to 34 ), dips persistently vary between $15^{\circ}$ and $30^{\circ}$, with a similar $20^{\circ}$ average value. Some of this dip may be due to hole deviation during drilling, but much of the inclination is probably real due to draping of local topographic irregularities above the unconformity, which reaches maximum inclinations of $15^{\circ}$ at the foot of the slope (Arthur and von Rad, this volume, fig. 7).

\section{Middle to Late Miocene Lithostratigraphic Unit 3}

This unit, dated middle to late Miocene, is a 207.4meter-thick light gray sequence of marly chalk and limestone with some mudstone. About one-half of this unit also appears to be slightly displaced; it is subdivided on the basis of the distinct lithologic change to Unit 4 and, at its upper contact, by the first downhole occurrence of a slumped zone which marks an unconformity. Twenty-six separate zones of slumping are present in Unit 3, with a wide variety of soft-sediment deformational structures: decollement zones, roll-up structures, rip-up clasts, pull-apart structures, microfaulting, and numerous types of folds (recumbent, isoclinal, overturned symmetrical and asymmetrical). These zones of slumping occur mainly in the upper two-thirds of this unit above an unconformity forming a hiatus between 12.4-11.4 m.y. (see Figure 14). In the lower third, there are numerous sand and silt laminae whose concentration appears to increase towards the lower contact with Unit 4. Of these laminae, about one-third are texturally graded. The basal portion of lithologic Unit 3 is a chaotic assemblage of deformed sediment clasts in a limestone matrix.

There is a considerable variation in sedimentary components, a reflection of the displaced sediment through the unit, but generally the sediment is composed of calcareous nannoplankton, foraminifers, quartz, clay, and minor components such as zeolites, pyrite, feldspar, glauconite, heavy minerals, dolomite, and biosiliceous debris. Quartz quantities increase markedly downsection according to smear-slide data, although this trend is not apparent in coarse-fraction analysis (see Sarnthein, in Sediment Summary Chart 1, back pocket). Clay minerals (see Chamley and d'Argoud, this volume) represent a mineral assemblage similar to those in the underlying Unit 4 with a high proportion of smectites, and lesser amounts of chlorite, mixed-layer minerals, kaolinite, and chlorite; the latter two, however, are present in distinctively higher amounts than in Unit 4 . In many respects, sediments in lithostratigraphic Unit 3 are quite similar to those in Unit 4, in both textural variations and mineral assemblages (including the coarse fraction); Unit 3 appears to be a transitional sediment facies between lithostratigraphic Units 2 and 4. This is also evident in overall carbonate contents, about 30 per cent on the average, and organic carbon content, which is less than 0.5 per cent.

Volcanic ash layers are present, some undisturbed and some incorporated into slumped zones (see Schmincke and von Rad, this volume). Zeolites are predominantly associated with these ashes (see Riech, this volume).
Mudstone intercalations between slump zones are primarily in the upper portion of this sub-unit. Otherwise, most of the autochthonous sediments are marly nannofossil chalks and nannofossil chalks, often with burrows. This would imply that soft-sediment deformation may have occurred due to slow downslope movement with little shear between slump zones.

\section{Late Miocene to Early Pliocene Lithostratigraphic Unit 2}

This unit consists of a hemipelagic sequence: displaced sediments are only noticeable as a few thin sandy silt layers and displaced biogenic shell debris. This is a 231.8-meter-thick interval which comprises light gray, marly nannofossil oozes and marly nannofossil chalk. Carbonate contents, averaging 55 per cent, are less variable than in either the underlying or overlying units. Organic carbon content is low, less than 0.5 per cent. Some gas expansion cracks were noticed in freshly recovered cores, but their density was considerably less than the density of such cracks described in Unit 1. Textural variations are not as extreme as in lithostratigraphic Unit 3, reflecting fewing allochthonous intervals. Volcanic ash layers are recognized on the basis of locally high zeolite concentrations and distinct intervals containing some glass shards (see Schmincke and von Rad, this volume).

Generally, the sediments of this lithostratigraphic unit are composed of calcareous nannoplankton and clay minerals, foraminifers (concentrated in some laminae), minor amounts of quartz, siliceous organisms, and dolomite. The clay-mineral assemblage is dominated by illite and smectite; kaolinite, chlorite, and mixed-layer phyllosilicates are less dominant, but are present in higher proportions than in lithostratigraphic Units 3 and 4.

\section{Early Pliocene to Pleistocene Lithostratigraphic Unit 1}

This uppermost lithostratigraphic unit, a 313-meterthick sequence of siliceous marly nannofossil ooze and marly nannofossil ooze, did not contain any apparent redeposited sediment. The important biogenic siliceous components form the basis for its designation as a separate lithologic unit. The upper portion of Unit 1 contains a variable quartz, calcareous nannofossil, organic carbon, and coarse-fraction assemblage allowing the definition of Sub-unit 1A. Sub-unit 1B does not have this wide compositional range, although the clay mineral suite (similar in mineralogical composition to lithologic Unit 2) is somewhat more variable than in 1A. In both sub-units, carbonate contents vary between 25 and 90 per cent, averaging about 57 per cent; organic content varies between 0.3 and 1.2 per cent with an average of about 0.5 per cent. Gas expansion cracks were common, accompanied by a strong $\mathrm{H}_{2} \mathrm{~S}$ smell. Pyrite is disseminated near or within these gas cracks as well as forming worm burrow fillings. Bioturbation was common throughout Unit 1. Vague bedding or banding within Sub-unit $1 \mathrm{~A}$ was suggested by slight color variations between white or light brown layers. 


\section{INTERPRETAION OF LITHOFACIES AND RELATION TO TECTONIC, CLIMATIC, AND OCEANOGRAPHIC EVENTS}

The sediment lithofacies cored in Holes 397 and 397A records a complicated sequence of events and processes operating along the northwestern African margin. By far the greatest amount of time (ca. 100 m.y.) is represented by the hiatus between Hauterivian and lower Miocene (latest Oligocene?) sediments. However, the assumption that Middle and Lower Cretaceous and Paleogene deposits once existed on the lower slope and uppermost rise off Cape Bojador is supported by the following findings: (1) the occurrence of some allochthonous sediment and redeposited fossil material of certain ages (e.g., late Aptian to Albian, Turonian to Coniacian, Upper Cretaceous and Eocene, late Oligocene) with the Neogene redeposited lithostratigraphic Unit 4 (see Arthur and von Rad, this volume); (2) the dredging and piston coring of sediment having "Middle" Cretaceous and Paleogene ages in nearby lower slope canyons (von Rad et al., 1978); (3) coring of Upper Cretaceous and Paleogene sediment in Site 369 on the intermediate slope (Lancelot, Seibold, et al., 1978); and (4) seismic evidence. Thus, it is likely that the hiatus resulted from a combination of slumping and erosion by bottom currents during one or more periods of increased bottomcurrent activity along the western African continental margin.

The following is a summary of the interpretation of sedimentary processes and paleoenvironment inferred from the Site 397 record and from the overall geologic history of this part of the African margin, based on other available information. The Early Cretaceous history of the "Cape Bojador margin basin" is discussed in a synthesis by Einsele and von Rad (this volume). Therefore, we will concentrate in this chapter on Cenozoic events and sedimentation (especially on the causes of the 100-m.y. hiatus), the early Neogene displaced sediment regime (see also Arthur and von Rad, this volume), the petroleum potential of the margin sequence, the Neogene evolution of Canary Islands volcanism (see also Schmincke and von Rad, this volume), and the sedimentary evolution and paleoenvironmental interpretation of the late Neogene (see also Cita and Ryan, this volume).

\section{Jurassic/Cretaceous Sedimentation}

The Jurassic and earliest Cretaceous history can only be inferred from seismic evidence (Wissmann, personal communication) and from the geological record of deep drill holes in the nearby coastal basin. A thick seismic interval below that penetrated by the drill string at Site 397 (approximately to a depth of 8 to $10 \mathrm{~km}$ subbottom) probably represents rapidly deposited (?Triassic to) Early Jurassic continental to evaporitic early rift sediments, thick shallow-water carbonates, and Late Jurassic to earliest Cretaceous carbonates and clastics which were sedimented during post-rifting subsidence.

The oldest sediments recovered in Site 397 are late Hauterivian. The 153 meters of monotonous, dark gray, finely laminated, silty claystones interbedded with siderite layers probably represent a distal prodelta facies of an Early Cretaceous prograding delta. Deltaic continental to lagoonal facies of coeval age are evident in the coastal Aaiun Basin and on the adjacent shelf (Einsele and von Rad, this volume). Conditions on the sea floor during deposition of the carbonate-poor mudstones seem to be predominantly oxygen-depleted. Low sea-surface productivity and relatively high input of land-derived organic matter were characteristic. Depths of deposition at Site 397 were probably only several hundred meters to a maximum of 1000 meters. Sedimentation rates were extremely high ( 75 to $150 \mathrm{~m} / \mathrm{m}$.y.).

Except for reworked fossils and sediment clasts in lithostratigraphic Units 4 and 5, Cretaceous sediment (post Hauterivian) was absent at Site 397. The record at Site 369 (Lancelot, Seibold, et al., 1978) might give a clue to the type of sediment originally deposited on the upper continental rise and later eroded. The olive-black silty nannofossil marlstones (late Aptian to Albian) reflect slightly oxygen-depleted upper slope conditions at an inferred paleo-water-depth of several 100 meters (Lancelot, Seibold, et al., 1978). They are probably underlain by shallow-water clastic deposits representing a deltaic plain or delta foreset environment, intermediate between the lagoonal facies of the shelf well Spansah 51A-1 and the prodelta facies of Site 397 (see Figure 3; Frontispiece; Einsele and von Rad, this volume; von $\mathrm{Rad}$ and Einsele, in press). Hemipelagic, gray-green mudstones and nannofossil marls with some chert are the most likely lithologic type for the Upper Cretaceous. Although some hiatuses are present in the Cretaceous of Site 369 (late Albian-Turonian and latest Cretaceous), it appears that pelagic or hemipelagic sediments were deposited at relatively slow rates from the AptianAlbian through Maestrichtian; these were probably typical of the margin sediments at that time.

\section{Early Cretaceous/Early Miocene Hiatus and Relation to Margin Sedimentation (M.A.A.)}

\section{Timing and Duration}

A surprising feature of passive margin drilling at Site 397 is that a sedimentary record for the interval representing late Hauterivian to latest Oligocene deposition is missing; i.e., a 100-m.y. hiatus. Upper Oligocene biogenic sediment of the Globorotalia opima opima foraminiferal zone (P.21) and nannofossil zone (NP 24) is the oldest apparent sediment overlying the unconformity, although this is interbedded with lower Miocene (N.5 to N.6 foraminiferal zone; NN 2 nannofossil zone) debris flows which directly overlie the hiatus (Cita et al., this volume). Rapid sedimentation in the form of debris flows, slumps, and turbidites was initiated in latest Oligocene-earliest Miocene time and continued through the mid-Miocene. It is likely that this hiatus represents large-scale erosion of sediment on the uppermost rise and at the base of the slope, rather than non-deposition. Furthermore, the erosion may have occurred within a relatively brief interval of time, from perhaps the late Eocene through Oligocene (about 15 m.y. or less), although it is possible that as many as four erosional 
events occurred (see below). Previous legs of the Deep Sea Drilling Project have demonstrated the widespread nature of an Oligocene hiatus in both the North and South Atlantic (Rona, 1973; Moore and Heath, 1977; Supko and Perch-Nielsen, 1977; van Andel et al., 1978; Fischer and Arthur, 1977), and it is not unlikely that the gap at Site 397 is related to this widespread event. Comparison of Site 397 with Site 369, Spansah 51A-1 (Figure 3 ), and influences from single- and multi-channel seismic records, however, make it more likely that this longduration hiatus is the result of several superimposed erosional intervals. For example, late Eocene-middle Eocene (6 m.y.), Maestrichtian to middle-Eocene (20 m.y.), and late Albian-Coniacian(?) ( $\sim 18$ m.y.) hiatuses have been identified nearby and upslope (Site 369, Leg 41, Lancelot, Seibold, et al., 1978); these times are noted as widespread hiatus intervals in the world ocean (Figure 6). Similar hiatuses (especially Paleocene to early Eocene and Oligocene) have been identified in many on- and offshore wells of the Aaiun Basin (von Rad and Einsele, in press).

Seibold and Hinz (1974) and Hinz et al. (1974) discussed the relationships of major seismic reflectors on the slope and rise seaward of the Aaiun Basin prior to DSDP drilling in the area. Two prominent reflectors $\left(D_{1}\right.$ and $\mathrm{D}_{2}$ ), thought to be continuous and isochronous throughout this region, were identified as unconformities and correlated with erosional gaps in Aaiun Basin stratigraphy. Because the overlying onlapping sediments were interpreted as the result of the Late Cretaceous transgression, Reflector $D_{1}$ was thought to be a Cenomanian hiatus. The record of Site 369, drilled at 1752 meters water depth on the upper slope (Figures 2 and 7), suggested that $D_{1}$ probably represented a middle to upper Eocene hiatus representing 6 m.y. duration, the reflector being due to the impedance change from hard argillareous porcelanite-rich mid-Eocene limestones to soft uppermost Eocene nannofossil marls (Lancelot, Seibold, et al., 1978). Site 397, drilled on the upper rise, demonstrated that the rise- $D_{1}$ (or R-9, see Figures 5 and 7) and rise- $D_{2}$ (or R-7) could not be correlated from the slope to rise (Figure 8). Tentatively, $D_{1}(R-9)$ in this region of the rise can be assigned to the top of a very thick, consolidated lower Miocene conglomeratic, pebbly mudstone at 960 to 985 meters below the sea floor.

A regional seismic reflector $\left(D_{2}\right)$ was also believed to be the "Oligocene to lower Miocene" hiatus (Seibold and Hinz, 1974; Hinz et al., 1974) because of the pronounced erosional features below the present shelf and the missing Oligocene record in the Aaiun Basin (Querol, 1966; AUXINI, 1969; Ratschiller, 1970). However, results from Site 369 showed this interpretation to be incorrect and Reflector $\mathrm{D}_{2}$ on the slope corresponds to the contact between lower Miocene nannofossil marl oozes and siliceous nannofossil marls. On the continental rise off Cape Bojador, $D_{2}$ is probably represented by a brief intra-middle Miocene hiatus ( $\sim 2$ m.y.) within a marly chalk sequence. In some seismic reflection profiles, a weak Reflector $D_{0}$ (R-10; Figure 7) actually correlates with the lower Miocene-Hauterivian hiatus which cannot be traced directly upslope to Site 396 (see
Site 397 Report; Wissmann; both, this volume). For a revised interpretation of the acoustostratigraphy of the Cape Bojador margin based on seismic sequences (instead of reflectors), see Hinz (this volume).

The major upper rise unconformity may be the result of local superposition of several hiatuses as previously suggested. After each erosion interval, a sediment wedge may have accumulated on the rise, to be swept away by subsequent events resulting in one $100-\mathrm{m}$.y. hiatus. Net sedimentation occurred between erosion of slumping events higher on the slope, resulting in several distinct intervals. The resulting relations are shown diagrammatically in Figure 9. At present, we favor the interpretation that earlier deposited material at the base of the slope was removed by erosion mainly during the (late Eocene to) Oligocene.

\section{Areal Extent and Volume of Sediment Removal}

As previously mentioned, the hiatus surface, just prior to deposition of the Miocene debris flows, corresponds to a very weak Reflector $\mathrm{D}_{0}$ or R-10 (Meteor M46-37 line, see Figure 7; see also Hinz, this volume, his fig. 3). Since this reflector cannot be unambiguously detected in most seismic lines, it is difficult to obtain an exact idea of the geometry and areal extent of the erosional surface. At this time we can only speculate about the volume of the wedge-shaped mass removed. If erosion occurred along at least a $300-\mathrm{km}-$ long and $20-\mathrm{km}$ wide strip of the margin from Cape Juby to Cape Blanc, and if we assume that 1 to $2 \mathrm{~km}$ of sediment were removed, a total of 0.6 to $1.2 \times 10^{4} \mathrm{~km}^{3}$ of sedimentary material was eroded and transported out of the region. The rate was 100 to $200 \mathrm{~m} / \mathrm{m}$.y. on an inclined surface of about $6000 \mathrm{~km}^{2}$ in area over about $10 \mathrm{~m}$.y. (or 33 to $66 \mathrm{~m} / \mathrm{m} . \mathrm{y}$. averaged over $30 \mathrm{~m} . \mathrm{y}$. if hiatuses from all times are combined). This erosion rate is phenomenal, especially considering that much of the sediment removed was probably well consolidated (possibly Early and Late Cretaceous mudstone and limestone, and early Tertiary muds, limestone, and chert).

Although we cannot give adequate evidence for the actual mechanism of erosion, we favor the interpretation of removal by intensified, margin-parallel bottom currents during the Oligocene climatic deterioration, aided by undercutting of bedrock by burrowing benthic organisms over lengthy time intervals. Johnson (1972), however, has demonstrated that up to several hundreds of meters of semiconsolidated late Eocene to late Neogene chalk was removed by thermohaline bottom currents in the equatorial Pacific. Mainly responsible for this process were deep bottom currents which were probably intensified up to $35 \mathrm{~cm} / \mathrm{s}$ velocities during relatively long glacial periods $(10,000$ to $100,000 \mathrm{yr})$ of the Pleistocene. A puzzling feature is the scarcity of debris from Early Cretaceous to Oligocene sediments or significant reworked microfossils in deposits which might be coeval to the erosion interval. Minor exceptions are upper Aptian to Albian nannofossils (Core 397-57), an upper Albian limestone (Core 397-87), a Turonian to lower Coniacian mudstone (Core 397-89), reworked Cretaceous and Eocene benthic foraminifers 


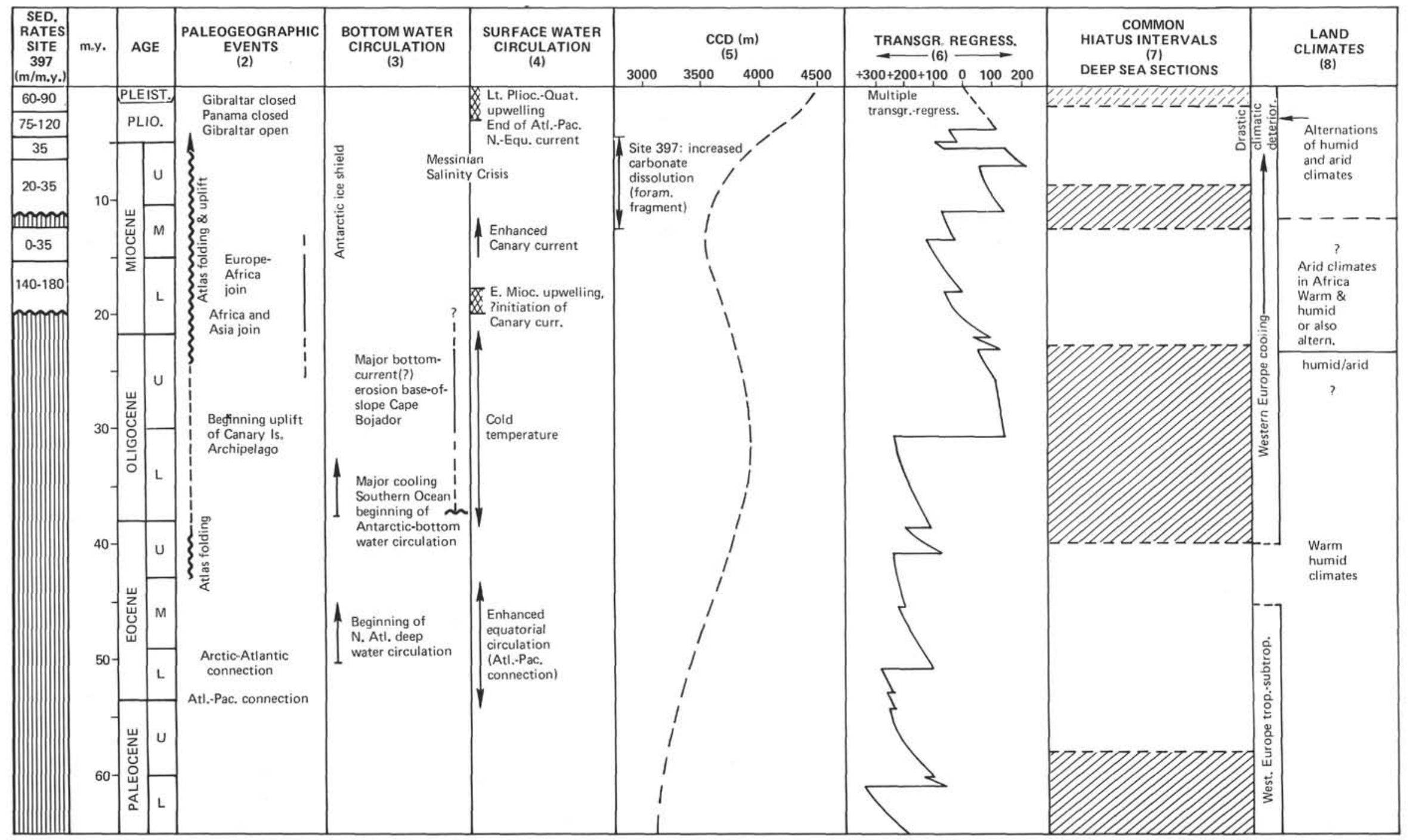

Figure 6. Correlation of rates of accumulation (m/m.y.) and selected paleoenvironmental data of Site 397 with global and regional climatic, tectonic, oceanographic, and sedimentation events (in part modified from Lancelot and Seibold, 1978). (2)-(4) modified after Berggren and Hollister and Cita and Ryan (this volume); (5) after Van Andel (1975); (6) after Vail and Mitchum (1977); (7) after Moore and Heath (1978); (8) after Sarnthein (1977a, b). 
in Unit 4, ?Eocene porcelanites and cherts, and the above-mentioned upper Oligocene hemipelagic sediments. The hypothetical strong bottom currents might have swept most of the pre-Miocene detritus out of the Cape Bojador marginal basin, towards the north.

\section{Possible Causes of Continental Margin Destruction}

The origin of such large-scale regional unconformities is probably due to a number of processes. Seibold and Hinz (1974), when discussing the significance of Horizon $\mathrm{D}_{2}$ as an Oligocene/Miocene hiatus, favored uplift of the continental margin and subaerial or shallow-water erosion from coastal basin to upper slope, then rapid subsidence to present depths. This uplift and erosion, they proposed, was in response to pulses of tectonic activity (Dillon and Sougy, 1974; Querol, 1966) during the Alpine orogeny in the High Atlas (Figure 6). As an alternative, Seibold and Hinz also suggested the possibility of an Oligocene/Miocene oceanic event related to: (1) lowering of sea level caused by variation in spreading rate (as proposed by Rona, 1973); (2) glaciation and the beginning of extensive Antarctic ice cap at about 20 m.y.B.P.; and/or (3) development of a circum-Antarctic current, the separation of Greenland from Europe, and changes in relief of the Isthmus of Panama.

There is no evidence for large-scale uplift of the Cape Bojador continental margin, although Tertiary folding and faulting of shelf and slope sediments has occurred farther north in conjunction with deformation of the High Atlas just onshore (Tooms et al., 1971; Summerhayes et al., 1971; McMaster and LaChance, 1968). Querol (1966) suggests that during the Eocene, the eastern part of the Aaiun Basin was uplifted. There is no indication of shallow-water fossils or sediments in the record of Site 369 on the intermediate slope; pelagic sedimentation has been relatively continuous there from late Eocene to the present (Lancelot, Seibold, et al., 1978). The margin has probably undergone continuous subsidence from its inception, although rates have slowed during the Late Cretaceous and Cenozoic (von Rad and Einsele, in press, fig. 7).

The following scheme is proposed for the large-scale back-cutting of the margin evidenced by Site 397 and correlation with seismic profiles and its relation to unconformities on the upper slope and shelf (Figures 9 and 10). Rapid climatic deterioration ensued from the late Eocene through the Oligocene (Figure 6; e.g., Savin et al., 1975; Shackleton and Kennett, 1974; Kennett, 1977). This cooling, pronounced in high latitudes, was related to growth of the Antarctic ice cap, possibly formation of sea ice around Antarctica (Hays et al., 1974; Kennett et al., 1975; van Andel et al., 1978), and the inception of the globe-encircling circum-Antarctic Current at 30 to 25 m.y.B.P. These events, coming after a relatively long period of warm, equable global climate and climatic stability, probably resulted in a pronounced change in oceanic circulation rates and bottom-water activity (e.g., Kennett et al., 1972, 1975; Davies et al., 1975; Fischer and Arthur, 1977; McCoy and Zimmerman, 1977). This rapid change in latitudinal climatic gradients and increased bottom-water production may be responsible for the widespread hiatuses which are predominantly Oligocene in the deep sea.

Furthermore, a pronounced Oligocene sea-level drop (Vail et al., 1977) occurs during the peak of the climatic deterioration following the major late Eocene cooling. This regression, actually mid-Oligocene $(\sim 30 \mathrm{~m}$.y. B.P.), has been previously attributed to a slowing of sea-floor spreading rates and resulting volume increase of ocean basins (Rona, 1973), but Pitman (in press) believes the regression much too rapid to be explained by this mechanism. It is possibly (at least partly) related to rapid expansion of Antarctic glaciers at this time and resultant lock-up of sea water as ice. The coincidence of large relative fall of sea level and increased circulation rates and bottom water production have probably combined to produce the observed hiatus relationships.

Querol (1966) has suggested slight uplift of the Aaiun Basin region to account for subaerial erosion during the Late Eocene to Oligocene, which caused Hinz et al. (1974) to consider $D_{2}$ as Oligocene. However, this exposure and erosion or nondeposition could easily have resulted from the pronounced Oligocene regression which Vail et al. (1977) believed brought the Oligocene coastline out to or beyond the present modal shelf edge. In a basin of reduced clastic influx, such as the Aaiun, it is likely that the observed unconformity resulted from nondeposition and slight erosion. Even though sea level dropped drastically, Oligocene sediments at Site 369 contain little evidence of increased terrigenous contribution or displaced very shallow-water organisms. Slumping, however, was recognized in the upper Eocene and lowermost Miocene sections. The middle to upper Eocene hiatus on the intermediate slope (Site 369) could have resulted from either removal of material by slumping or erosion by currents; Oligocene sedimentation rates are higher than either Eocene rates or those at the Oligocene/Miocene boundary (Lancelot, Seibold, et al., 1978).

The first canyon erosion on the intermediate Cape Bojador slope started during the Paleocene to Eocene. During the late Oligocene to earliest Miocene, an accentuated sea-level fall (about $50 \mathrm{~m} / \mathrm{m}$.y.; Pitman, in press) surpassed the subsidence rate (about $13 \mathrm{~m} / \mathrm{m}$.y.; von Rad and Einsele, in press) and moved the strandline beyond the shelf edge. This favored slumping and turbidity currents cutting canyons along the slope, and sculpturing and oversteepening the base of the slope. The older (?Eocene) canyons were more deeply incised into Paleogene and Cretaceous strata, and many new slope valleys were created which were partly filled during the early to middle Miocene by slumps, debris flows, and proximal turbidites (von Rad et al., 1978).

The pre-early Miocene hiatus on the upper rise revealed by drilling at Site 397 probably resulted from erosion by enhanced geostrophic currents which affected only the lowermost slope and uppermost rise at depths greater than about 2500 meters during the Oligocene, whereas the upper Eocene and Oligocene is preserved at 


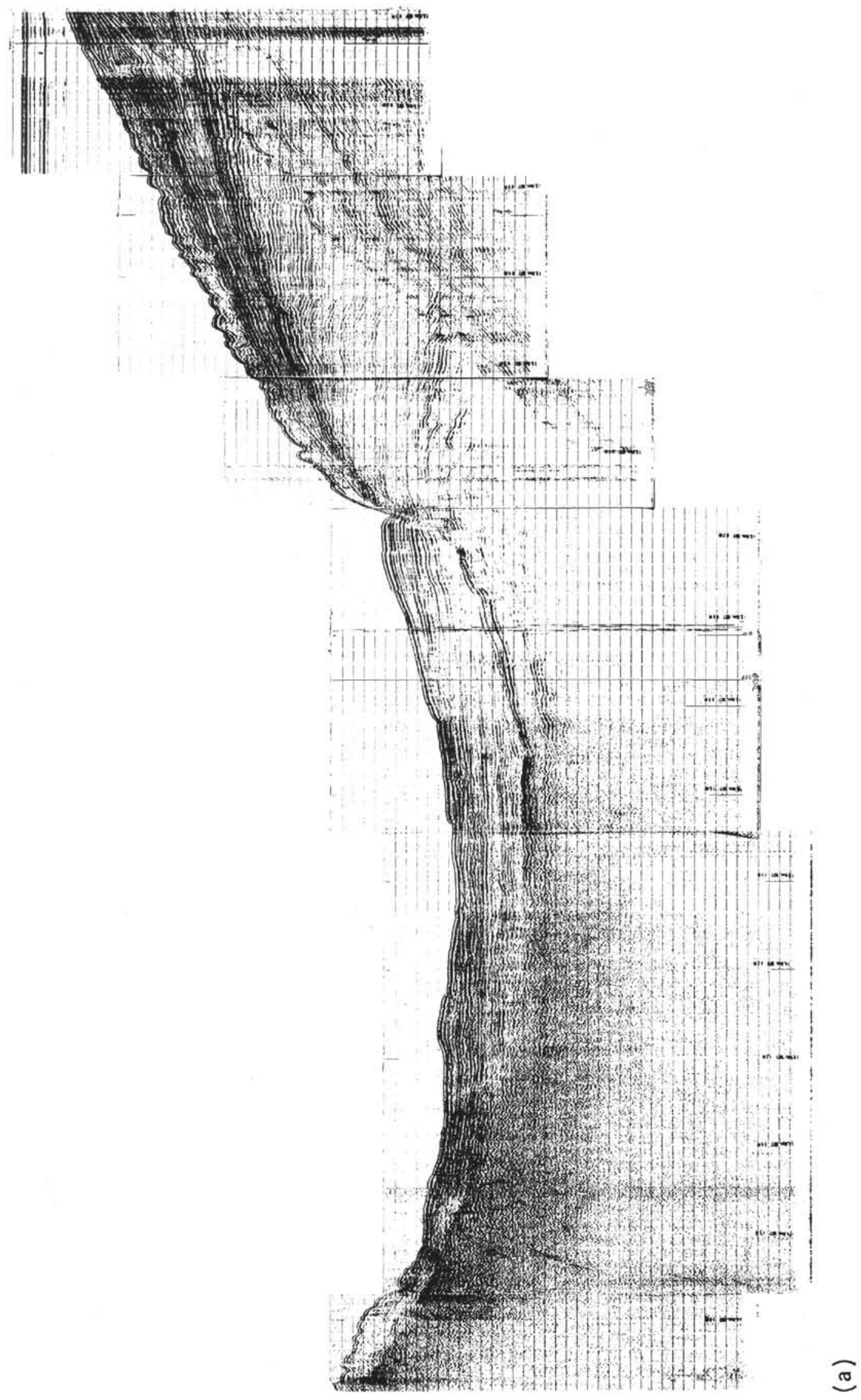




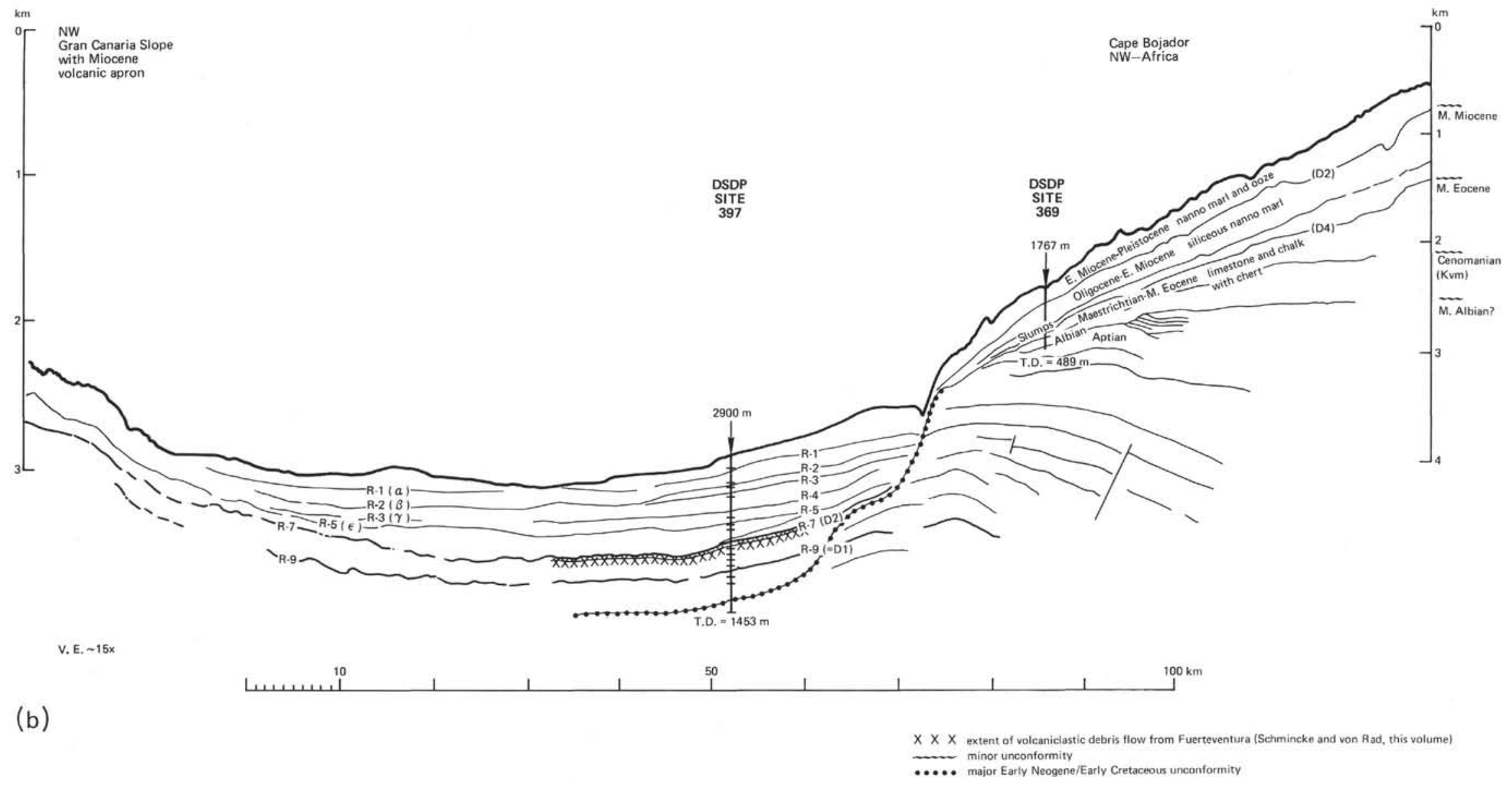

Figure 7. Seismic reflection profile M46-37 (BGR, Hannover, $R / V$ "Meteor" 1977) across the outer Cape Bojador continental margin between DSDP Sites 360 and 397 (for location, see Figure 2). (a) Original analog record (horizontal lines are spaced at 0.1 sec. intervals two-way travel time). Seismic source: $3.5 \mathrm{kHz}$ airguns. For digital single trace recording of this profile (processed by BGR) see Site 397 Report. For interpretation of nearby multi-and single-channel profiles, see also Hinz (this volume). (b) Line drawing of profile M46-37 (interpretation, courtesy of G. Wissmann, Hannover) showing acoustic reflectors identified at Sites 369 and 397 (see also Sediment Summary Chart 1 in back pocket, this volume). Note that it is impossible to correlate seismic reflectors between both sites across the major horizontal unconformity underlying the lowermost slope or uppermost rise. 1 = extent of volcaniclastic debris flow from Fuerteventura; 2 = unconformity (schematic, right-hand edge of figure). 


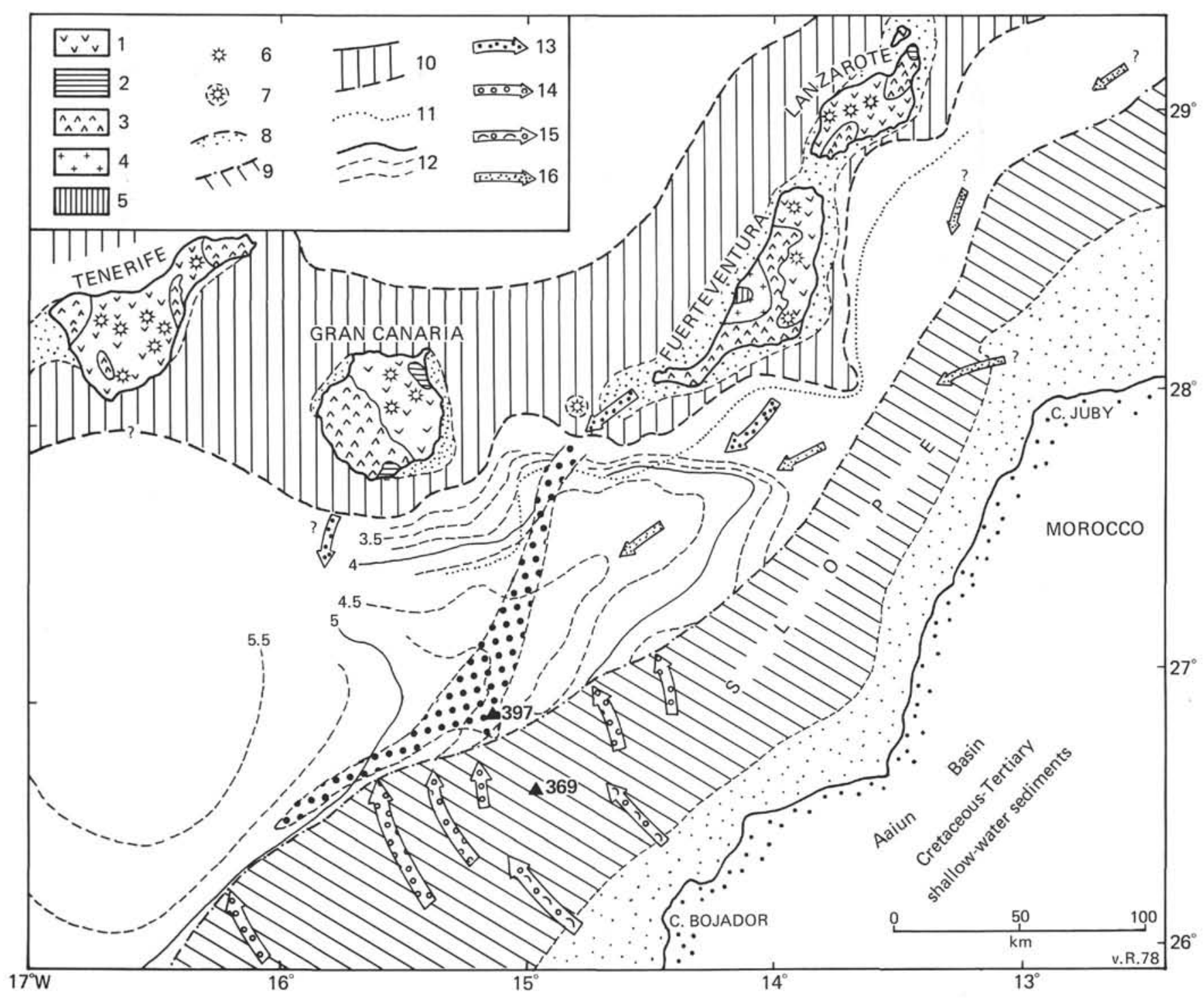

Figure 8. Depth contours of seismic Reflector R-7 (i.e., D 2 of Hinz et al. 1974) in seconds (two-way travel time) between the "volcanic mass" of the Canary Islands and the base of the continental slope lafter G. Wissmann in Schmincke and von Rad, this volume fig. 1). Arrows indicate the tentative provenance and transport directions of allochthonous Neogene lithofacies types F-1, 2, 3, 4A, and 4B (see Figure 14). R-7 depth contours indicate middle Miocene paleobathymetry. For explanation of symbols (1) to (6) for generalized geology of Canary Islands, see Schmincke and von Rad (this volume, Figure 1); $7=$ young submarine volcano; $8=$ continental or island shelf with shelf break; $9=$ base-of continental-slope boundary; 10 = "volcanic mass" or "socle," partly overlain by young sediments and/or pyroclastics; 11 = seaward boundary of "volcanic apron," over-and underlain by sediments; 12 = depth contours of seismic Reflector $R-7$ in seconds two-way travel time below sea level, indicating the approximate paleobathymetry during middle Miocene times. Arrows demonstrate inferred transport directions for: $13=$ volcaniclastic debris flows $(F-4 B)$ dotted area $=$ seismically detected extent; $14=$ debris flows and mud turbidites (F-2, 3, 4A) from Cape Bojador slope (and outer shelf); $15=$ distal turbidites $(F-1) ; 16=$ proximal shell and quartz granule-rich debris flows $(F-4 C)$ from outer shelf. Source for (7), (10) to (12): G. Wissmann (BGR, Hannover, personal communication).

Site 369 and in the sediments dredged from the lower slope canyons (2500 to $2000 \mathrm{~m}$; see von Rad et al., 1978). A number of workers have documented the erosion and shaping of lower continental slope and rise sediment off eastern North America by Western Boundary counter-currents flowing southward at velocities greater than $15 \mathrm{~cm} / \mathrm{s}$ today (e.g., Hollister and Heezen, 1972, and references within; von Stackelberg et al.,
1976). We envision something similar to this having occurred along the eastern Atlantic margin of Africa during the Oligocene climatic deterioration. Though Eastern Boundary currents are not typically as strong as Western Boundary currents today, the presence of an Oligocene hiatus in deeper eastern Atlantic basin sites probably attests to increased deep-water flow rates capable of sediment erosion. This deep-water mass move- 


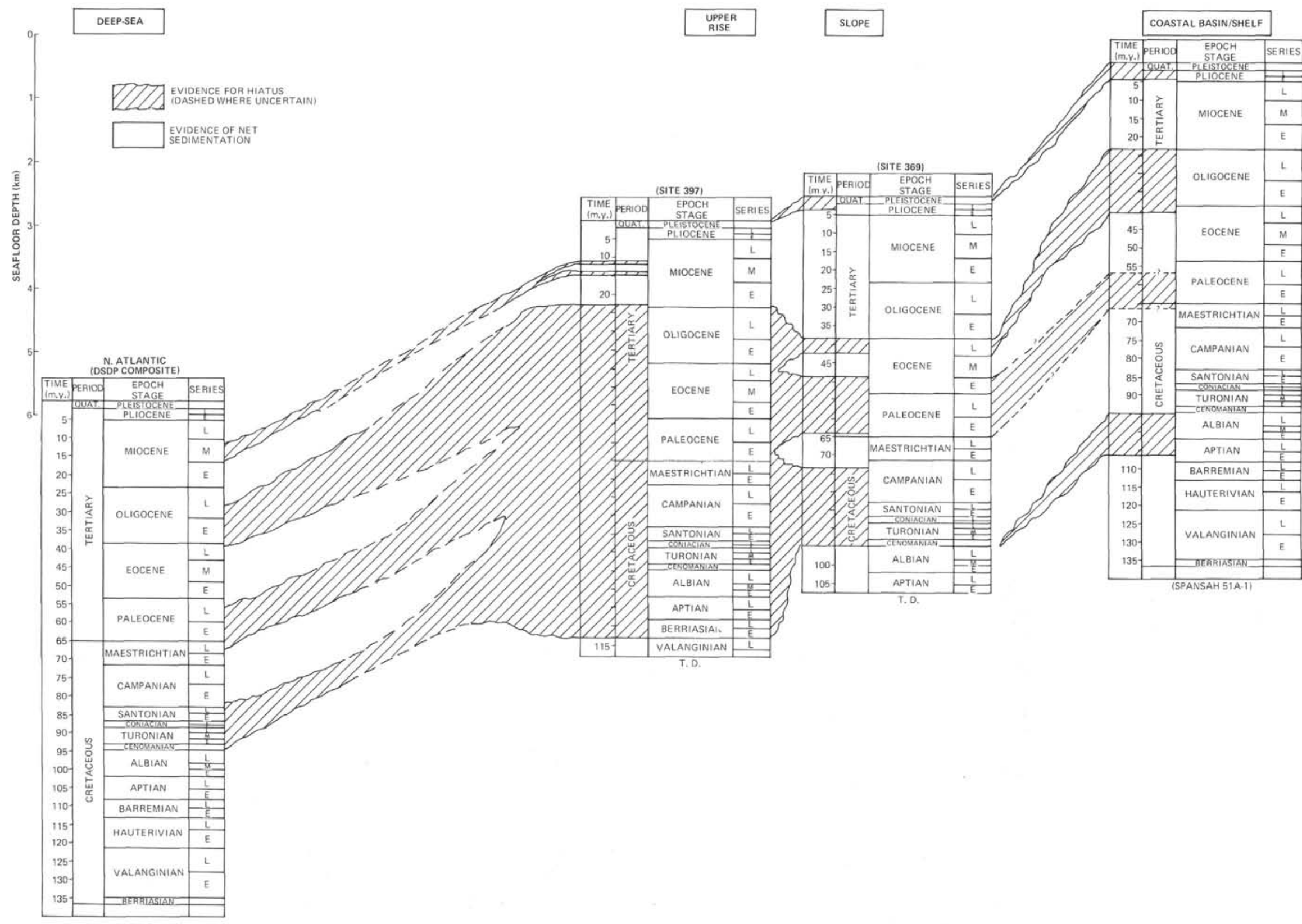

Figure 9. Schematic hiatus time diagram (abyssal plain-rise-slope-shelf/coastal basin) showing time represented by known hiatuses (see text). Spansah 51A-1 after CONOCO (1969); Site 369 after Lancelot, Seibold et al. (1978); DSDP North Atlantic composite from Moore and Heath (1977); Fischer and Arthur (1977). 


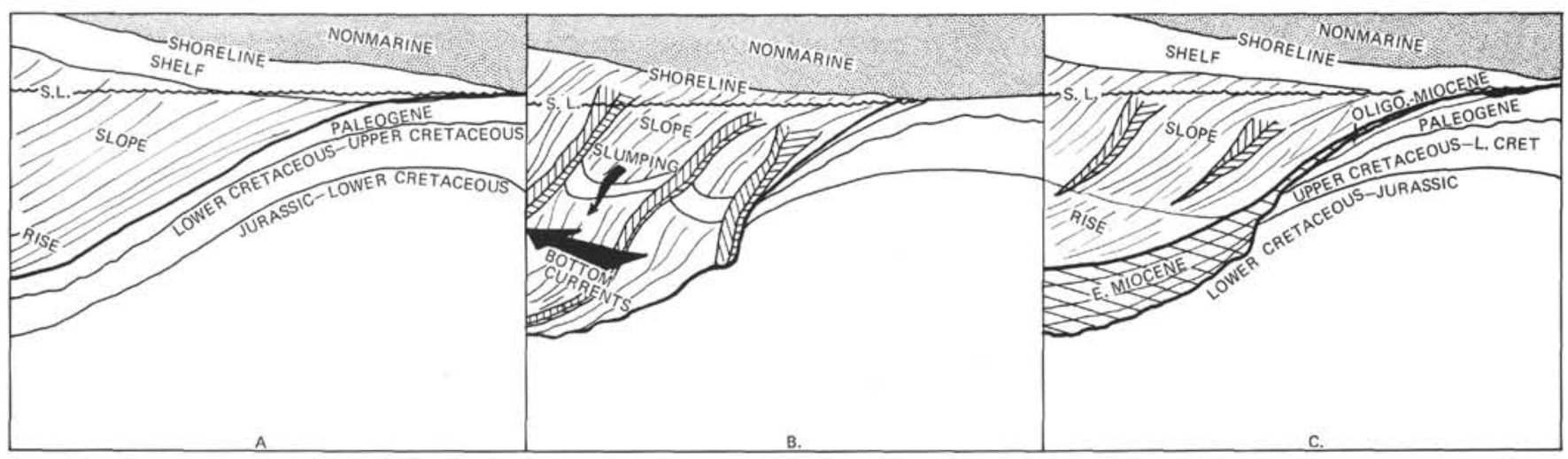

Figure 10. Schematic illustration of Cape Bojador margin showing erosion by bottom currents, slumping, canyons, and stable upper slope sediments. Sequence shows hypothetical (A) middle Eocene, (B) Oligocene-early Miocene, and (C) late Miocene configurations and depicts interrelationship of sea level drop, bottom current scour, and unconformities with subsequent infilling (see text).

ment could have been caused by production of the Oligocene equivalent of Antarctic Bottom Water which moved up from the south, crossed the Atlantic from west to east through gaps in the Mid-Atlantic Ridge (Romanche and Vema fracture zones), and displaced generally warmer and less dense North Atlantic water masses. There appears to be evidence for increased circulation along the Moroccan Continental Rise capable of moving sediment, for example, during the recent past (Jacobi et al., 1975).

The actual cutting-back of the lower slope and rise off the Aaiun Basin was probably accomplished by erosion and undercutting of the rise-slope prism, slumping of materials from the lower slope, and submarine canyon formation (all operating concurrently). Upper slope gradients were stable enough to continue to accumulate sediment, while upper rise and lower slope gradients were steepened (Figure 11); sediment did not accumulate during the erosion interval. The heads of most submarine slope valleys in this region, which apparently predate Miocene sedimentation (von Rad et al., 1978), are generally situated at about 1000 meters or deeper with very few reaching the shelf edge (Seibold and Hinz, 1974; Hinz et al., 1974). There is a pronounced increase in gradient of seismic Horizon $\mathrm{D}_{\mathbf{1}}$ (maximum gradient 8 per cent) at about 1700 to 2000 meters depth (Meteor 25, A-2), whereas the gradient of the present slope between Sites 369 and 397 is only 3 per cent. Unstable gradients and undercutting of the lower slope led to continued slumping and cutting of incisions. The erosive, northwest-flowing geostrophic currents were apparently capable of removing all detritus from the upper rise depositional site. The eroded material may have been transported northward into the deep Moroccan Basin; no record of the sediment masses removed can be noted in seismic profiles or drill holes farther out on the rise. Oligocene quartz-rich siliceous oozes, however, representing a distal terrigenous facies, are preserved in the abyssal plain Site 138 west of the Canary Islands (Figure 4).

Erosion of the upper continental rise ceased abruptly during the early Miocene when cascades of debris derived from sediment of nearly equivalent age farther upslope accumulated on the erosion surface at the juncture of the upper rise and lower slope. The almost complete absence of recognizable pre-late Oligocene detritus in the allochthonous sequence suggests that incision by submarine canyon cutting and slumping of the Cretaceous to Paleogene sequence exposed on the lower continental slope had virtually ceased by the earliest Miocene (NN 2). The source for the debris flows was mostly contemporary sediment which was highly unstable on the oversteepened lower slope. The decreased effectiveness of deep geostrophic currents during latest Oligocene-early Miocene may be due to a circulation regime adjusted to the climatic change (or adjusted gradients) and consequently lowered circulation rates, or to uplift of the Cape Verde Rise and Canary Island Ridge during the early to middle Miocene (Lancelot, Seibold, et al., 1978; Dillon and Sougy, 1974) which may effectively have blocked and diverted the marginsweeping currents.

\section{Early Neogene Displaced Sediment Regime (M.A.A.)}

\section{Lithology and Composition}

The sediment to be discussed here comprises lithologic Unit 4 (see Site 397 Report), i.e., Section 397-79-2 to Core 397-104 and Core 397A-2 to Section 397A-34-1 (a total thickness of about $544 \mathrm{~m}$ ). The age of these slumps, conglomerates, pebbly mudstones, sandy pebbly mudstones, mudstones, turbidites, and volcaniclastic conglomerates-sandstones ranges from early Miocene, with intermixed reworked Oligocene, to middle Miocene. Resedimentation of this material on the upper continental rise appears to have taken place shortly after initial deposition upslope; sedimentary clasts within pebbly mudstones are generally the same age as pebbly mudstone matrix and hemipelagic intercalations.

\section{Lithofacies Descriptions and Definitions}

A variety of interbedded lithotypes is present. To facilitate description and sampling on board ship, each major lithotype within the displaced sediment interval 


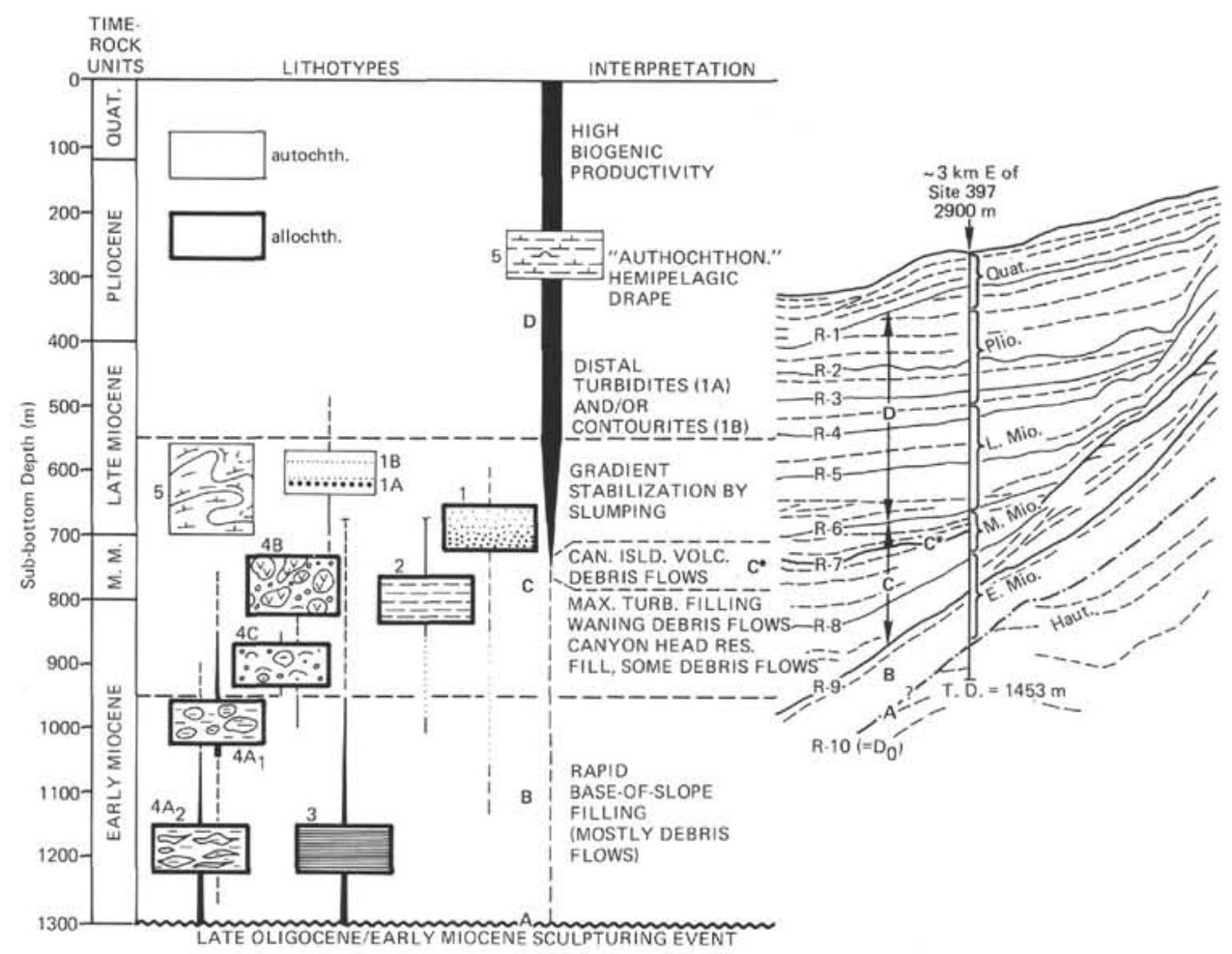

Figure 11. Lithology, age, temporal distribution, and interpretation of allochthonous facies types $F-1,2,3,4 A, 4 B, 4 C$ and autochthonous hemipelagic sediments (F-5) in the Neogene of Site 397. Part of seismic reflection profile (M25-A2) is included to show the revolutionary sequence of flysch-type sedimentation, as expressed by the upward decrease of downslope gradients of major reflectors. Letters $A-D$ in both diagrams designate successive phases of erosion, gravitative, and hemipelagic sedimentation (see text).

was given a numbered lithofacies designation (see Arthur and von Rad, this volume). Five major lithofacies were recognized.

Recognition and subdivision is based on such parameters as grain size and sorting, color, mineralogy and clast composition, carbonate content, and sedimentary structures. Although each major lithofacies type has a distinct end-member as defined in Core 397-87 (see Plate 1 in Arthur and von Rad, this volume), there are some gradational intervals which could not be placed easily in a pigeonhole classification. Subdivision is based on lithologic descriptions from smear slides and visual core observations, $\mathrm{CaCO}_{3}$ (shipboard and shorebased analyses), organic carbon analyses (shipboard and DSDP shore-based data from C. Cornford), coarsefraction examination, and clast description. Paleontological information provided by G. Lutze, P. Čepek and $\mathrm{F}$. Wind have aided in description and interpretation.

Lithofacies F-1 through F-4 are interpreted as displaced or allochthonous sediment; each type probably had a somewhat different source, mode of transport, and deposition. All lithofacies types are not cooccurring; several of them typify only certain portions of the sequence. There appears to be a genetic relation- ship between several of them (see Figure 11), as well as an overall evolution from rapid deposition of material transported primarily as debris flows (F-4) to deposition mostly from silty or muddy turbidity currents (F-1, F-2, and F-3) and from suspension (F-5).

Throughout lithologic Unit 4, the displaced (or allochthonous) sediment types are interbedded with a lithotype interpreted as the product of normal relatively slow pelagic sedimentation (autochthonous). These nannofossil marlstones to limestones are termed F-5 and are characterized by light blue-gray to green-gray colors (typically 5B7/1-5/1), varying carbonate contents (ranging from 20 to $80 \mathrm{wt}$. $\%$, with lowest values near the base of the section, increasing toward the upper part of lithologic Unit 4), and common bioturbation. Detailed descriptions and illustrations of all lithofacies can be found in Arthur and von Rad (this volume).

\section{Age Relations of Sediment}

The occurrence of the thick redeposited gravitative sedimentation sequence was unexpected in this geologic and tectonic setting, which was characterized by the lack of major tectonic activity and the absence of a major delta debouching in the vicinity. Nor do these strata appear to represent development of a typical deep-sea 
fan, although information on lateral facies changes is lacking because no offset holes were drilled; however, seismic reflection profiles help to estimate the probable lateral extent and the dispersal pattern of this displaced sediment facies (Figure 8). Today, after the midMiocene uplift of the Canary Island volcanoes, these sediments occupy an elongate trough between the Canary Islands to the northwest and continental slope/ rise boundary along the northwestern African margin towards the southeast. The displaced sediments discussed here are represented approximately by the interval between acoustic horizons $\mathrm{D}_{0}$ (R-10, the 100-m.y. hiatus) and $\mathrm{D}_{2}$ (R-7; see Figures 7 and 11) and amount to more than $10^{4} \mathrm{~km}^{3}$ in volume.

Although it has been recognized that the continental rise is a depository for much of the sediment initially deposited on the outer shelf and slope (e.g., Stanley and Unrug, 1972; Kelling and Stanley, 1976), an accumulation of such vast amounts of displaced material primarily in the form of slumps and debris flow deposits is unexpected in this passive margin setting. Although huge submarine slides and slumps have occurred during Quaternary times on the northwestern African margin southwest of Cape Bojador (Embley, 1976; Jacobi, 1976), most sedimentation in this area appears to have been by slow pelagic or hemipelagic deposition since the middle Miocene, as illustrated by the upper Neogene section of hemipelagic muds recovered in Site 397 and results of previous DSDP legs (e.g., Legs 14 and 41). The sequence of lithotypes, sedimentary structures, and depositional mechanisms in the early Neogene of Site 397 most resembles some alpine proximal flysch sequences, specifically those composed predominantly of "fluxoturbidites"' (e.g., Dzulinski et al., 1959; Unrug, 1963; Stanley and Unrug, 1972). This term is used for comparison, but it is noteworthy that Walker (1970) has urged the abandonment of such a frequently misapplied term in favor of utilizing "disorganized conglomerates."

Site 397 (and Site 369) is not presently located in the pathway of any major submarine canyons or valleys (e.g., see Seibold and Hinz, 1974; von Rad et al., 1978), and the upper Neogene and Quaternary record reflects this intercanyon position (Figure 2). The closest major submarine canyon is located about 20 nautical miles northeast of Site 369 . No major slumps, debris flow, or turbidity current deposits occur in the upper Miocene to Quaternary section. Thus, unlike during the early Neogene, the slope is no longer actively retreating in this area; undisturbed hemipelagic sediments predominate, although some large slides and debris flows have occurred during the Quaternary further south (Embley, 1976) and minor slump scars were noticed from PDR records upslope of Site 397 (Figure 2). It is not likely that this site was ever in the axis of a major submarine canyon, even though displaced sediments dominate the lower Neogene section. Turbidite sands and silts, though present, are rare and atypical of proximal fan and fan channel deposits (e.g., Stanley, 1975; Mutti and Ricci-Lucchi, 1973; Nelson and Kulm, 1973), and there is an absence of disorganized sands and pebbly sands (often termed fluxoturbidites) which are common to very proximal fan channels (Stanley, 1975; Mutti and Ricci-Lucchi, 1973). There can be at least two reasons for this. First, as mentioned above, the site has always had an intercanyon location; the second is explained below.

It is known that no major river systems debouch onto the shelf in this region. During Oligocene-early Miocene time, the shelf was starved of sediment (which consisted mostly of calcareous material), and Miocene-Pliocene phosphatized hard grounds are not uncommon (von Rad et al., 1978; Tooms and Summerhayes, 1978; Summerhayes et al., 1977). Thus, there was probably no significant source of sand from river systems or shelf, except possibly for calcareous sands/silts composed of shelf benthos and planktonic foraminifers and quartz, phosphatic grains, and glauconite winnowed from older sedimentary bodies on the shelf and upper slope, or from aeolian processes active in the region (e.g., Sarnthein, 1978a). Even the deposits of proximal fan valleys, if developed during this time, may not have been composed of significant amounts of sand and silt. Sand falls or so-called grain flows typical of certain submarine canyons heading on terrigenous outer shelf regions (Shepard and Dill, 1966; Stanley, 1975; Stauffer, 1968; Carter, 1975) may not have been quantitatively important resedimentation processes. Also, as seen on seismic reflection profiles (e.g., Seibold and Hinz, 1974; von Rad et al., 1978), most canyons did not head on the shelf, i.e., only on the lower to middle slope. Thus, very few canyons would readily tap any shelf sands available, and most resedimented material probably would consist of upper to lower slope muds, possibly admixed with some shelf silt/sand. This model is able to explain the type of sedimentation seen in the allochthonous sediment sequence of Site 397.

Based on seismic and sedimentologic evidence, the sequence of lower to middle Miocene displaced sediment recovered at Site 397 probably represents sedimentation at the base of an actively receding slope, located between major submarine canyons. Earlier slumping and back-cutting or shelfward erosion of the lower continental slope probably took place during the PaleoceneEocene and the Oligocene (e.g., von Rad et al., 1978). The deposits of this period of slumping and erosion may be farther out on the continental rise, or possibly swept from the basin by strong currents; very little material older than early Miocene or latest Oligocene is included in lower Miocene debris flow deposits at Site 397. This also constitutes evidence that the site was not receiving material from nearby submarine canyons; such occurrence would yield greater quantities of older materials (which eroded from the canyon walls) in debris flows. As the slope continued to recede by slumping and/or erosion during the early Miocene, slumps and debris flow deposits came to rest at the site. Seismic line "Meteor"' M25-A2 (see Figure 7) shows that Site 397 must have been near the break of slope during the early Miocene. Hampton (1972) has discussed evidence that submarine slumps and slides generate debris flows and 


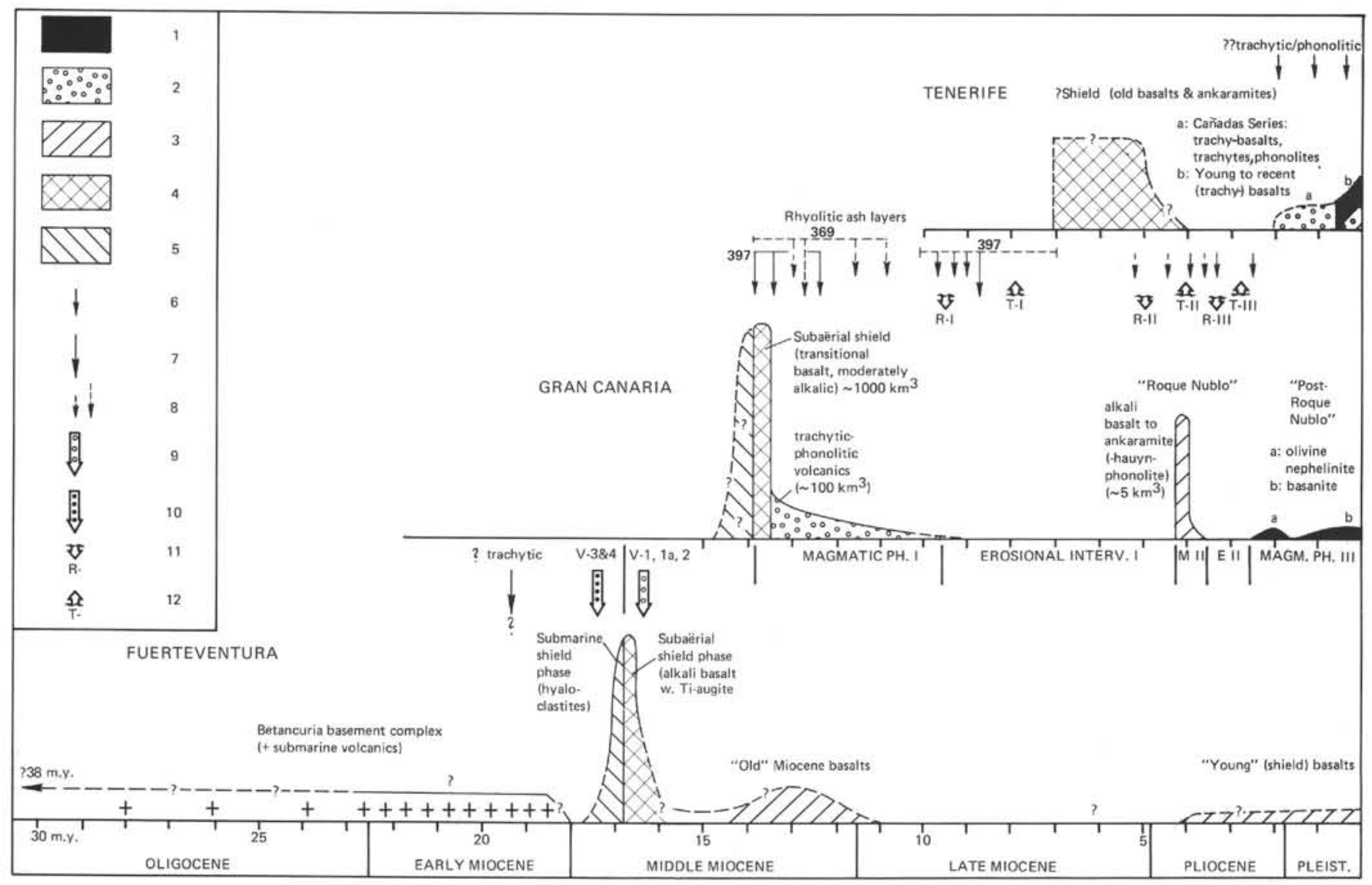

Figure 12. Schematic diagram showing generalized type, age, and duration of magmatic (M) and erosional (E) phases, transgressions (T), and regressions (R) on Tenerife, Gran Canaria, and Fuerteventura (in part modified after McDougall and Schmincke, 1977). Age and composition of volcaniclastic sandstones and ash layers found in Sites 369 and 397 (Schmincke and von Rad, this volume) indicated in diagrams of those islands which are considered to be the source areas. $1=$ extremely silica-undersaturated, alkalic magmas (nephelinite); $2=$ trachyte, phonolite, etc.); $3=$ alkali basalts, basanite; 4 = subaerial shield phase (moderately alkalic basaltic to mugearitic magmas) typical of all Canary Island shields (Schmincke, 1976) and inferred for Fuerteventura from Site 397; $5=$ submarine shield phase (hyaloclastites, only inferred from Site 397 evidence for Fuerteventura; $6,7=$ of air-fall ash layers from Site $397(7=>10 \mathrm{~cm}$ thick); $8=$ thin or thick air-fall ash layers, respectively, from Site 369 (see Rothe and Koch, 1977); $9=$ volcaniclastic sandstones/ conglomerates (debris flows $V-1,1 \mathrm{~A}$, and 2; mainly subaerial source); 10 =hyaloclastites (debris flows $V$-3 and 4 ; mainly submarine source); 11,12 = regressions $(R)$ and transgressions (T), after Lietz and Schmincke (1975, their fig. 4).

turbidity currents. Jacobi (1976) and Embley (1976) have shown that this, in fact, has taken place on the upper continental rise of northwestern Africa at slopes as low as $0.1^{\circ}$ during the Quaternary. Quaternary slides and slumps on the lower slope progressively give way seaward to debris flow deposits and then turbidites (cf. Stanley, 1975). This is also evidenced by seismic reflection profiles, shallow-penetration high-resolution (3.5 $\mathrm{kHz}$ ) echograms, and piston cores. Based on this reasoning, most of the slumps and slides responsible for the generation of the lower Miocene debris flow deposits may lie slightly upslope, although some slumps are interbedded with debris flow deposits at Site 397. In fact, upper Paleogene slump deposits and a small-scale middle Miocene debris flow (incorporating pebbles of Albian to Oligocene age) were reported from lower slope canyons southwest of Site 397 (von Rad et al., 1978, their fig. 7).
Sand layers of lower Oligocene and lower Miocene sand layers at DSDP Site 138 (the outermost continental rise west-southwest of the Canary Islands) and at Site 368 (Cape Verde Rise) are contourites (Sarnthein, 1978a), whereas the well-sorted lower Miocene quartz sandstones of Site 139 (from the intermediate rise) have recently been interpreted as "eolian sand turbidites" (Sarnthein and Diester-Haass, 1977).

\section{Evolution of Sequence and Sediment Sources}

A series of phases in sedimentation can be recognized within the redeposited sediment interval (Unit 4) following the pre-early Miocene sculpturing event or slope back-cutting phase (A). These are portrayed in Figure 11 and discussed in detail in Arthur and von Rad (this volume).

After the erosional event and resulting hiatus, a rapid base-of-slope filling stage of sedimentation occurs 
(lower to middle Miocene, 1300 to $950 \mathrm{~m}$ sub-bottom). Slump units, debris flows, and thick mud turbidites derived from contemporaneous sediment draping the slope region (transverse fill, Figure 8) were deposited at rates in excess of $175 \mathrm{~m} / \mathrm{m}$.y. over a 3-m.y. period ( 20 to 17 m.y.B.P.). The matrix of pebbly mudstones and mud turbidites is primarily dark colored and relatively organic carbon-rich. Clasts in the pebbly mudstones (debris flows) consist primarily of hemipelagic or pelagic marlstones and mudstones of nearly the same age as burrowed autochthonous light colored marlstones interbedded with the pebbly mudstones at Site 397. Many of the clasts are deformed, contorted, and stretched indicating that they were relatively unindurated at the time of transport. Some shallow-water sedimentary detritus and shell debris occurs in sandy, pebbly mudstones within this interval (see Site 397 Report; Arthur and von Rad; both, this volume). Clasts having ages older than late Oligocene are rare but do occur (see Arthur and von Rad, this volume).

A gradual transition from primarily slump and pebbly mudstone deposits to predominantly sandy mudstones containing shallow-water calcareous fossil debris, lighter colored turbiditic mudstones and sandstones intercalated with burrowed marly chalks marks the beginning of gradient stabilization and upbuilding of the upper rise (Phase C, $\sim 950$ to $540 \mathrm{~m}$ ). The local gradients apparently decrease throughout deposition of this interval (dips of $<5^{\circ}$ as opposed to local $20^{\circ}$ dips in sediment of Phase B), as can be seen on seismic profiles (Figure 11). Sedimentation rates during Phase $C$ were rapid during the late-early Miocene ( 150 to $175 \mathrm{~m} / \mathrm{m} . \mathrm{y}$.) but declined during the middle Miocene to less than 25 $\mathrm{m} / \mathrm{m}$.y. A maximum of reworked shallow-water fossils occurs at the base of this interval ( 950 to $900 \mathrm{~m}$ subbottom), suggesting that shelf sedimentary material contributed significantly to sediment at this time (Site 397 Report), possibly through a local submarine canyon heading near the shelf edge. The shelf assemblages were mixed with slope sediment and benthic foraminifers during transport to the site. The influence of shelf and slope sediment gradually waned during Phase $\mathrm{C}$ and, by the latest Miocene, very little allochthonous material arrived at the site. Phase $\mathrm{C}$ ended with a sequence of slump units apparently derived from just upslope. Following this, no displaced sediment was deposited (late Miocene through Recent) at Site 397 during the hemipelagic drape Phase D. Sedimentation during Phase D and the influence of climate is discussed in a later section. The entire sequence from Phases B through D represents diminution of slope gradients and gradual stabilization of sediment.

Whereas most of the redeposited sediment at Site 397 was derived from source areas probably directly upslope from the site, redeposited volcaniclastic sediment during a brief period from 18.5 to 14.5 m.y.B.P. (Phase $C^{*}$ ) appears to have been derived from Fuerteventura in the Canary Island archipelago (Figures 9 and 10). These volcaniclastic conglomerates and sandstones are treated in the next section (see also Schmincke and von Rad; Arthur and von Rad; both, this volume).

\section{Evolution of Canary Island Volcanism (U.v.R.)}

\section{Pre-Neogene History}

Little is known on the Mesozoic to Paleogene history of the Canary Island region. Only on the strongly uplifted $\left(3\right.$ to $\left.5 \mathrm{~km}^{3}\right)$ and deeply eroded island of Fuerteventura is a 2- to 3-km-thick sequence of Early to Late Cretaceous sediments preserved (Rothe, 1968). At its base, this sequence consists of flysch-like, cross-laminated siltstone-shale alternations which are Valanginian to Hauterivian. In contrast to Rothe's (1968) attempt to relate this sequence to shallow-water sequences in the Tarfaya Basin, the Early Cretaceous sediments on Fuerteventura can now be interpreted as distal deep-sea fan or upper to intermediate continental rise deposits (Bernoulli et al., in press). Upsection, this flysch sequence grades into Middle to Upper Cretaceous pelagic radiolarian cherts and thinly bedded recrystallized limestones and shales, similar to Lower Cretaceous pelagic carbonates and shales on Maio (Cape Verde Islands). The nature of the deep-water Cretaceous sediments from Fuerteventura and their good correlation with the thick clastic Lower Cretaceous sequences of Sites 397 (prodelta muds) and 416 (distal turbidites; Lancelot, Winterer, et al., 1976) suggest that no subaerial "Canary Island Ridge" existed during the Mesozoic (and early Paleogene. Also, seismic reflection profiles indicate that most of the continental rise prism was already deposited before the uplift of this volcanic ridge divided the rise into two parts: a 500-km-wide outer rise to the west of the Canaries (Uchupi et al., 1976) and a $100-\mathrm{km}$-wide upper rise to the east.

The maximum age of the individual Canary Islands decreases westward from Fuerteventura to Gran Canaria, Tenerife, Hierro, and La Palma (Figure 12); the oldest igneous rocks occur in the basement complex (Betancuria Massif) on Fuerteventura. The age of these ultramafics, gabbros, diorites, and syenites and the associated dike-in-dike complex which cuts both plutonic rocks and Mesozoic sediments, is far from clear: the published $\mathrm{K} / \mathrm{Ar}$ age determinations (Abdel Monem et al., 1971; Grunau et al., 1975) scatter from 38.5 m.y.B.P. (Oligocene/Eocene boundary; probably an unreliable value) to less than 12 m.y.B.P. (middle Miocene). Hence, it is unlikely that the volcanic history on the Canary Islands dates back much beyond the Oligocene, or even the Miocene (see also Schmincke, 1976). This is also verified by seismic profiles (see Frontispiece; Figures 7 and 8) which indicate that the oldest volcanic wedges (i.e., "volcanic apron") at the southeastern foot of the islands extend into sediments of early Neogene age (see also Grunau et al., 1975, their fig. 6).

\section{Early to Middle Miocene Uplift and Shield Stage}

Because our knowledge of the volcanic history is restricted to the subaerial stages of volcanic development, we are completely ignorant about the nature and age of the large submarine pedestals of the volcanic islands (see Frontispiece). Hence, it is an important result of Site 397 that several thick volcaniclastic debris flow units were penetrated which provide us with a new 
type of information on the early history of volcanism, uplift, and emergence of the Canary Islands (see Schmincke and von Rad, this volume).

In a very schematic way, Figure 12 shows the volcanic evolution of three characteristic Canary Islands of decreasing age: Fuerteventura, Gran Canaria, and Tenerife (Schmincke, 1976), together with the age and type of volcaniclastic layers recovered in Sites 397 and 369.

The oldest pyroclastics (Section 397A-23-3) which precede the volcaniclastic debris flow units, are altered vitreous tuff layers ( 2 to $8 \mathrm{~cm}$ thick) of trachytic composition which are the product of large explosive eruptions about 19 to 20 m.y.B.P. (lowermost Miocene; see Figure 12). The source is unknown, but could have been Fuerteventura (or Lanzarote), judging from age data of similar rock types on these islands (Schmincke and von Rad, this volume). Unless we assume the existence of an early Miocene volcanic island which since has been eroded, this means that part of Fuerteventura must have been above sea level before its major shield-building phase. To our knowledge, these ash layers are the oldest, comparatively precisely dated volcaniclastics on or around the Canary Islands.

The age of the major shield-building phase which produced great volumina of moderately alkalic basalts at high eruption rates and during short episodes is very poorly known for most Canary Islands (Schmincke and Flower, 1974; Schmincke, 1976). From a large number of new K/Ar dates, McDougall and Schmincke (1977) discovered that the subaerial shield-building phase (which produced $>95$ per cent of the volcanic edifice of Gran Canaria) occurred about 13.5 m.y.B.P. over a time interval of less than 0.5 m.y. On Fuerteventura, a range of 12 to 17 (20) m.y.B.P. was estimated for the shield phase on the basis of very few, scattered age data (Abdel Monem et al., 1971); however, given more data, it is likely that the shield here also was built during a geologically short episode (Schmincke, 1976).

The age of emplacement of the volcaniclastic debris flows V-1 to V-4 at Site 397 can be dated rather accurately with the aid of the foraminiferal and nannobiostratigraphy of the rapidly deposited $(130 \mathrm{~m} / \mathrm{m} . \mathrm{y}$.) overlying and underlying sediments (Figure 13): their age ranges from about 17.6 to 16.5 m.y.B.P., i.e., about 3 m.y. prior to the formation of the subaerial shield of Gran Canaria, and much older than the oldest volcanics of other islands west of Gran Canaria (Schmincke, 1976). Therefore, Fuerteventura was the most likely source area for the volcaniclastic debris flows of Site 397. The older debris flows (V-4 and V-3) are hyaloclastites (i.e., shattered by pyroclastic or hydroclastic processes) with abundant palagonitized sideromelane shards which appear to be almost entirely of submarine origin. Hence, Schmincke and von Rad (this volume) speculated that debris flows V-4 and V-3 (about 17.6 to 17 m.y.B.P.) record the submarine stage of Fuerteventura's major shield-building phase (see also Lopatin, this volume).

At about 17 to 16.5 m.y.B.P. (upper-lower to lowermiddle Miocene), subaerial volcanism of basaltic composition was fully active on Fuerteventura(?), as re- corded by the "epiclastic" fragments (i.e., fragmented by erosion) of mostly tachylitic to fully crystallized basalt, trachyandesite, trachyte, and microgabbro in volcaniclastic debris flows V-2, V-1, and V-1a (Schmincke and von Rad, this volume). Alkali basalts with $\mathrm{Ti}$-augite, and derivative volcanic rocks are the dominant or only source rock. Because of their age, these rocks cannot be derived from Gran Canaria (Figure 12).

Not before the growing seamount reached into shallower water was erosion able to attack the volcanic mass by the destructive forces of currents and waves and (during the beginning subaerial stage) by winds and streams ("shallow-submarine" to "subaerial shieldbuilding stage": MacDonald and Abbott, 1970). Apparently, the later growth of the volcanic island was also interrupted by periods of subsidence or sea-level rise with surf erosion which supplied huge amounts of volcanic debris to the shelf and canyon heads (Lietz and Schmincke, 1975). Because the island shelf probably was always narrow and the slope very steep, the rapid supply of sand to gravel sized volcanic clastics produced slumps which developed into grain flows, debris flows, or turbidity currents (see Arthur and von Rad, this volume). Most likely these slumps and mass flows were triggered by volcanic earthquakes.

The extent of the middle Miocene debris flows can be traced as a series of strong reflectors between R-7 and R-8 on seismic reflection profiles (see Figure 9). According to G. Wissmann's interpretation (personal communication, 1978), the debris flows have an average thickness of 20 to 30 meters and can be mapped as a relatively narrow ( 5 to $25 \mathrm{~km}$ ) tongue over a length of at least $220 \mathrm{~km}$ (area $=\sim 2000 \mathrm{~km}^{2}$; see Figure 8). If we assume an average thickness of 25 meters (including several flows up to $10 \mathrm{~m}$ thick, such as V-1, V-3, V-4), we arrive at a volume of $50 \mathrm{~km}^{3}$, a value which is very similar to the one calculated by Schmincke and von Rad (this volume). According to Wissmann's data, the debris flow might be derived from Fuerteventura or from a ridge between Gran Canaria and Fuerteventura, which shows submarine volcanoes (not covered by Recent sediments); from there, it flowed in a southsouthwesterly direction by spreading out near Site 397, and continued in its path along the foot of the continental slope towards the southwest (Figure 8). The paleodepth of the south Canary Island channel during middle Miocene times is roughly indicated by the depth contours of seismic Reflector R-7.

Obviously, the "South Canary Island Channel" between the Cape Bojador margin and the islands Lanzarote to Gran Canaria did not form before the early Neogene uplift of the archipelago: the oldest part of this elongate basin which later became a Neogene depocenter (near Site 397) is located between LanzaroteFuertventura and Cape Juby (? earliest Miocene), whereas the southern part (east of Gran Canaria) might have been formed during the early-middle Miocene.

In total, the volcaniclastic debris flows which can be traced on seismic profiles as a series of very strong reflectors (between R-7 and R-8; Figure 7) might have 
deposited at least $50 \mathrm{~km}^{3}$ of volcanic (including entrained sedimentary and biogenic) sediment. This is less than one per cent of the total volume of the subaerial plus submarine shield of Gran Canaria $\left(8400 \mathrm{~km}^{3}\right)$, as estimated by McDougall and Schmincke (1977). The main shield of Fuerteventura might have had a similar volume. The estimate of roughly $50 \mathrm{~km}^{3}$ in material shed from Fuerteventura does not include the volume of the seismically detected "volcanic aprons" around the volcanic islands (Figure 8; Frontispiece) which are underlain by (?) pre-middle Miocene sediments (Wissmann, this volume). It is unclear whether these thick volcanic wedges also represent volcaniclastic debris flows from the nearby islands, or flows and hyaloclastites from submarine volcanoes (see Grunau et al., 1975).

\section{Middle Miocene to Quaternary Volcanism, as Inferred From Air-Fall Ashes at Sites 397 and 369}

The igneous components of the volcaniclastic debris flows originated from (1) shard and pillow formation during a shallow submarine stage ("hyaloclastites"), or (2) from the erosion of volcanic and plutonic rocks of basaltic composition deposited and cooled on land ("epiclastic" volcaniclastic sandstones). As we have seen, components were transported by gravity-driven mass flows on the sea floor to their present site of deposition. These deposits are confined to the deepest, "ponded" parts of the "South Canary Island Channel" (Figure 8).

A completely different depositional process has to be invoked for the middle Miocene to Quaternary ash layers found at Sites 397 and 369: highly explosive eruptions of more differentiated rhyolitic, trachytic, and phonolitic magmas on the volcanic islands resulted in the vertical projection of high eruption columns, lateral eolian transport by high-altitude winds, and sedimentation by passive fall-out through the water column. Hence, the distribution of these ash layers is independent of basin morphology, as evidenced by the presence of thin Miocene ash layers high up on the Cape Bojador slope (Site 369: Rothe and Koch, 1978). Today, the predominant atmospheric transport of volcanic dust from the Azores is eastward to southward, i.e., opposite to the direction of the trade winds (Freed and Watkins, 1975). If similar winds prevailed at high altitudes during the Neogene, this would explain the presence of comparatively thick 12 to $14 \mathrm{~m}$.y.-old ash layers (maximum 20 to $25 \mathrm{~cm}$ ) at Site 397 (Cores 397-73 and 397-77) and of more or less coeval (10.5 to 13.5 m.y.) thinner (maximum $10 \mathrm{~cm}$ ) layers at Site 369 (Core 369A-5), 100 to 300 $\mathrm{km}$ south and southeast of the inferred eruption centers on the western Canary Islands.

Distinct ash layers in Sites 397 and 369 reflect wellknown and dated volcanic events on the nearby Canary Islands and possibly even different stages in the volcanic evolution of the entire island group (see Schmincke and von Rad, this volume).

According to Schmincke (1976) and McDougall and Schmincke (1977), Gran Canaria shows a remarkably cyclical magma evolution (Figure 12), as outlined below: (1) Shield-building "Magmatic Phase I" (at about 13.6 m.y.B.P.) with high eruption rates of muguritic to moderately alkalic basaltic composition (volume $\left.=1000 \mathrm{~km}^{3}\right)$; followed by trachytic to phonolitic volcanism $\left(100 \mathrm{~km}^{3}\right)$; (2) "Erosional Interval I" (9.5 to 4.5 m.y.B.P.; 5 m.y. duration), devoid of any volcanic activity. Fossil alluvial fans indicate a first regression (10 m.y.B.P.); terraces suggest a first transgression (T-1; Lietz and Schmincke, 1975); (3) Second magmatic phase ("Roque Nublo Sequence," 4.6 to 3.8 m.y.B.P.), characterized by strongly alkalic, silica-unsaturated, $\mathrm{H}_{2} \mathrm{O}$-rich magmas (alkali basalt-ankaramitehauynphonolite) with slow eruption rates and small volumina $\left(5 \mathrm{~km}^{3}\right)$; (4) Second erosional (non-volcanic) hiatus; (5) Third magmatic phase (Quaternary) with very small volumina of extremely silica-unsaturated alkalic magmas (nephelinites, basanites) and many (? mantlederived) harzburgite nodules.

Significantly, the age of many ash layers detected in the middle Miocene to Quaternary sediments of Sites 369 and 397 correlates with the eruption of derivative magmas during the above-mentioned magmatic intervals. Most ash layers of both sites, and all thicker ones, contain vesicular felsic glass of rhyolitic to phonolitic composition and are about 7 to 14 m.y. old (middle to lower-upper Miocene); i.e., they coincide roughly with Gran Canaria's most voluminous Magmatic Phase I (Figure 12). Although the petrography and chemical composition of the glass in those ash layers has not yet been studied in any detail, it is likely that Gran Canaria was the source area.

A few thin ash layers of Site 397 and Site 369 are about 3.5 to $5(6)$ m.y. old (latest Miocene to earliest Pliocene) and might be derived from Gran Canaria's second magmatic phase ("Roque Nublo Series"). Only a few thin ash layers occur in the late Pliocene and Pleistocene of Site 397. If they can be proven to be of trachytic or phonolitic (i.e., highly differentiated alkalirich) composition, they should come from late Pliocene to Pleistocene explosive eruptions of the western Canary Islands on Tenerife (Canadas Series and Pico de Teide), La Palma, or Gomera.

\section{The Neogene Hemipelagic Drape: Evolution Since Early Neogene, Lithology, and Paleoenvironmental Inter- pretation (M.S.)}

Approximately 10 m.y. of hemipelagic deposition succeeded $10 \mathrm{~m} . \mathrm{y}$. of the early Miocene displaced sediment regime (Figures 13 and 14). The hemipelagic section can be subdivided by means of interval sedimentation rates and coarse-fraction composition into two major approximately 5-m.y. phases: pre-Messinian and post-Messinian (uppermost Miocene).

A detailed consideration of coarse fraction and other compositional evidence allows for a more accurate subdivision of the Neogene into 15 lithologic sub-units which aid in understanding paleoenvironmental evolution. Each sub-unit comprises an interval of some 1 to 2 m.y.; seven are found in the lower Neogene, and eight in the upper Neogene (see Table 1 and Figure 14). Table 1 briefly summarizes the main characteristics of the 


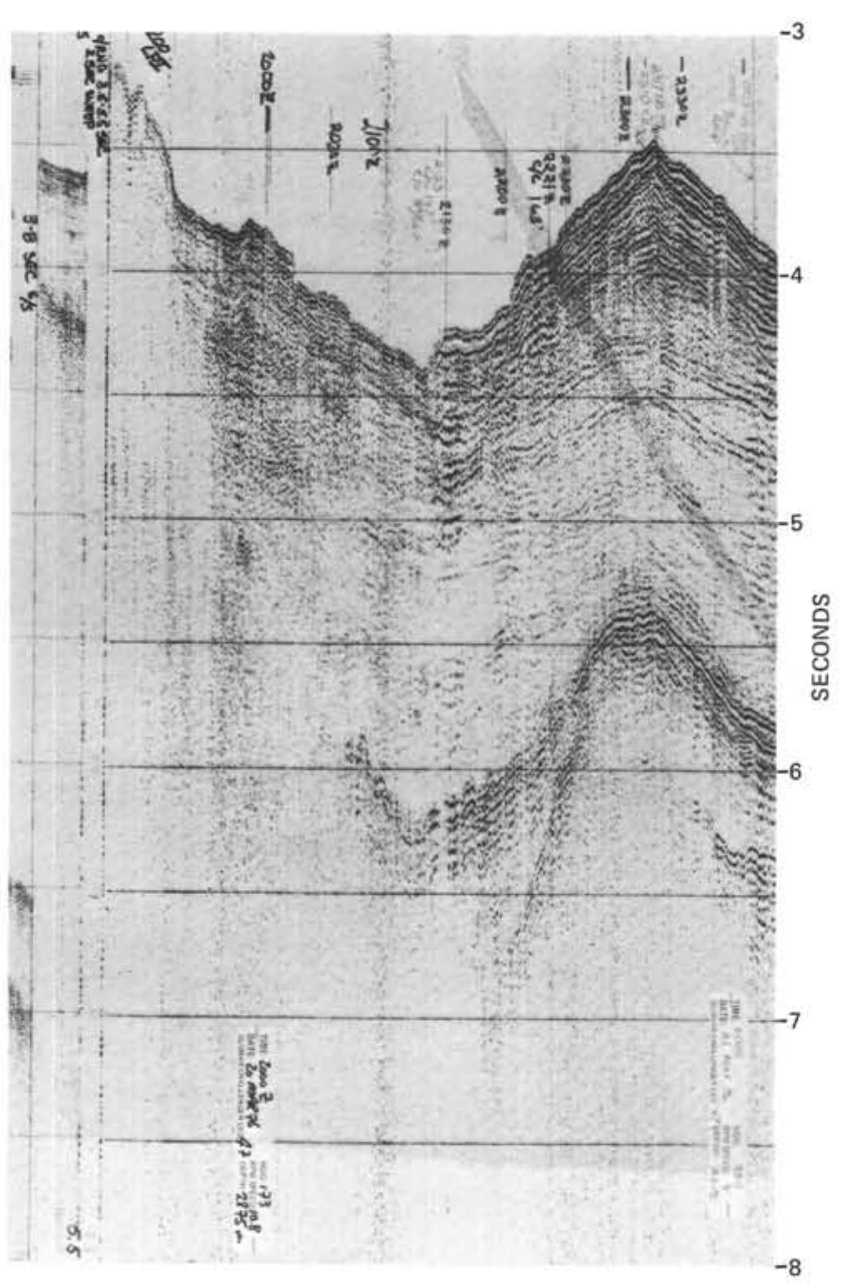

Figure 13. Seismic section showing bedded character of hemipelagic drape. Glomar Challenger Profile 2, March 1976.

lithologic sub-units. They comprise differing sediment thicknesses of 20 to 175 meters, due to variable accumulation rates and stratigraphic gaps. Based on variations in carbonate content, grain size, quantitative micropaleontological parameters, and stable isotopes, Cita and Ryan (this volume) have also interpreted the ocean paleoenvironment during the past $7 \mathrm{~m}$.y. Independently from our study, which is mainly based on the composition of the coarse fraction, these authors distinguished six intervals ("steps") for the late Miocene to Quaternary record of Site 397 which are very similar to the subdivisions used in our Figure 14.

\section{Duration of Major Events (sedimentary regimes)}

With regard to the lower Neogene (Figure 14), it is interesting that most of the environmental stages and "events" which controlled the sedimentation phases (lithologic sub-units) during the upper Neogene and Quaternary (provided that age calibration of the $\mathrm{N}$ and $\mathrm{NN}$ zones is basically sound). For example, major signs of volcaniclastic deposition (during Sub-unit 4A) are confined to only 1.4 m.y., i.e., 17.2 to 15.8 m.y. B.P.
Also, the impressive supply of shallow-water carbonate detritus in the pebbly mudstones immediately below, in Sub-unit 4B, is limited to some $1.7 \mathrm{~m}$.y., i.e. 18.5 to 16.8 m.y.B.P. Similarly, the major phases of turbidite deposition at the site are found during short time intervals of 0.5 to 1.0 m.y.: around 18 to 19 m.y.B.P., 16.5 to 17 m.y.B.P., 15.6 to 16 m.y.B.P., and framing the mid Miocene hiatus at 13.5 to 12.5 and 11.5 to 10.9 m.y.B.P. The latter two groups of turbidites have in common the coarse grain sizes of quartz at the base of the sand layers.

The same order of time span seems to apply for the influence of several components which indicate the evolution of climate and oceanography during the Neogene. However, these time units (corresponding to the lithologic sub-units) only present a long-term average record of paleoenvironment. This is due to the inadequate time resolution of the generally wide-spaced standard sampling in DSDP cores, and the reduced time scale used in Figure 14. The actual major climatic fluctuations emerge somewhat in the pattern of numerous short-term peaks and troughs suggested in the various components in Figure 14; these occur in stages as short as 10,000 to 40,000 years (corresponding to 1 and 3 of sediment at high sediment accumulation rates) and in secondary phases of 2500 and 4000 years of duration. This has been shown by careful calibration against the late Pleistocene oxygen-isotopic record (Lutz et al., this volume). Shackleton and Cita (this volume), Cita and Spezzibottiani (this volume), and others show that longterm shifts and changes of the amplitudes of climate fluctuation apparently control most of the larger compositional vatiations which influence the lithologic subunits.

\section{Plankton Productivity and Terrigenous Volcanic Input versus $\mathrm{CaCO}_{3}$ Dissolution and Bottom Erosion: Control of Sediment and Accumulation}

\section{Upwelling Events and Pelagic Sediment Accumulation}

Despite complicated conditions of displaced sediment accumulation, the first marked appearance of biogenic opal (18 to 20 m.y.B.P.) (altered to opal-CT; see Riech, this volume) can be explained by an early Miocene upwelling event which induced increased fertility in the surface water such as observed in modern environments (Diester-Haass, 1977). This event immediately succeeds the large pre-Miocene hiatus and fits well with the early Miocene upwelling record from almost all remaining DSDP sites along the African continental margin south of the Canary Islands: Sites 369, 138, 139, 368, and 366 (Diester-Haass, 1978; Sarnthein, 1978a). It also corresponds to early Miocene horizons of increased calcium carbonate dissolution reported from equatorial oceans (Berger, 1973; van Andel, 1975). This might possibly result from the establishment of a permanent steep temperature gradient between the polar and tropical regions related to the development of (only southern?) polar to tropical surface water-mass belts (Kennett, 1977). The upwelling perhaps was also related to a first appearance of the Canary Current. 


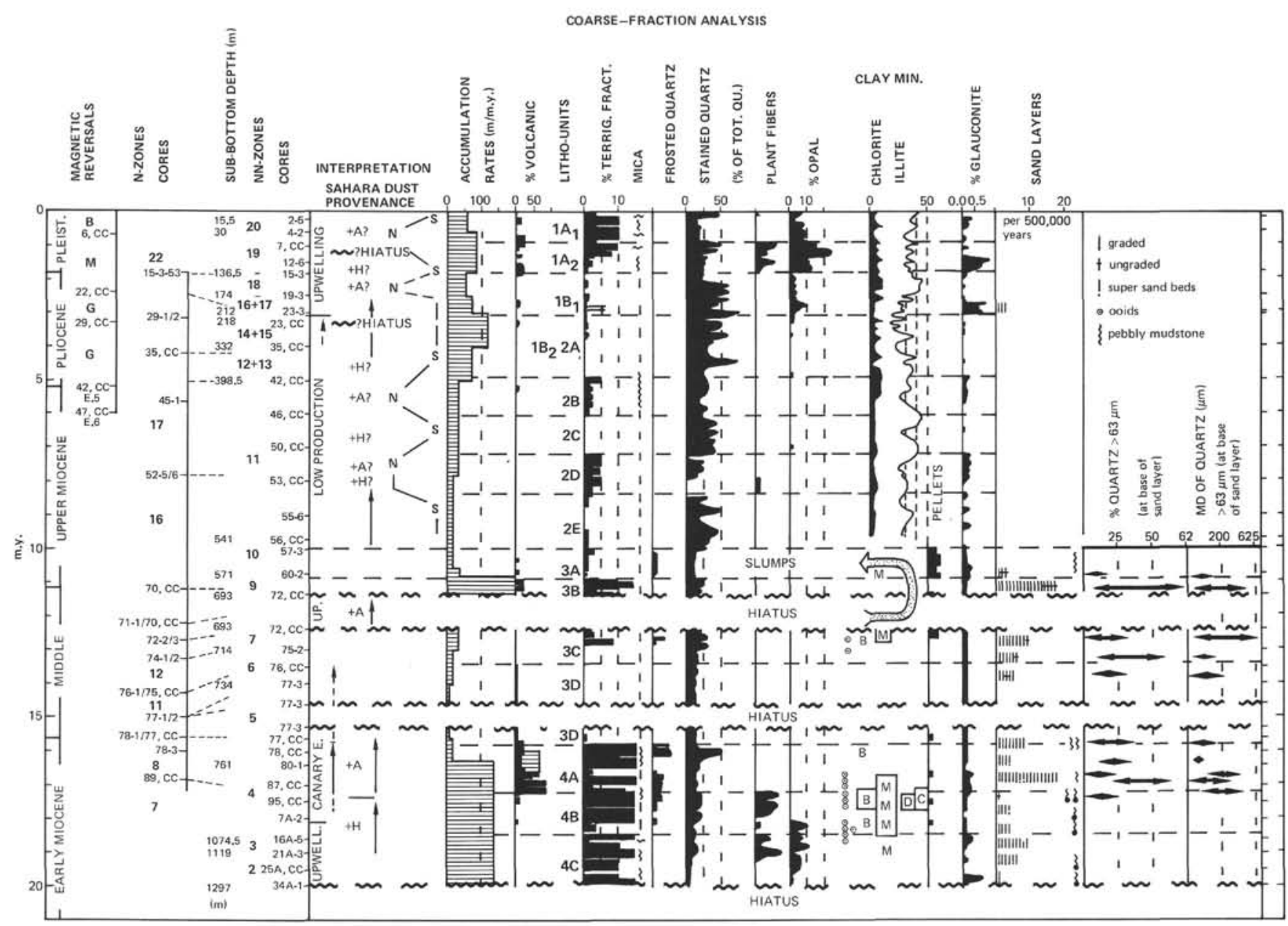

Figure 14. Summary chart of the Neogene environmental evolution at DSDP Site 397. Magnetic reversals by Hamilton (this volume). $N$ zones by Cita (this volume), age calibration by Ryan et al., 1974. NN zones and stratigraphy used for Summary Chart by Čepek and Wind (this volume). Absolute age scale (m.y.) and accumulation rates after NN zone age calibration by Martini (1976), partly modified following Berggren (1973); Cita, this volume (e.g., stratigraphic gaps); Gartner, 1977; and Ryan et al. (1974). Interpretation: $N=$ North Sahara; $S=$ South Sahara; $A=$ arid; $H=$ humid; $E=$ event. Pliocene stratigraphic gaps by Hamilton, this volume. Results of general coarse-fraction analysis and sandlayer study: own data, supplemented by Diester-Haass (this volume) at \% terrigenous fraction, \% stained quartz, \% opal, $\%$ glauconite. Shallow-water skeletal grains: $M=$ mollusks; $B=$ barnacles; $D=$ decapods; $C=$ solitary corals. Slump derivation dated by coccoliths, Cepek and Wind this volume; clay minerals from Chamley and d'Argoud (this volume).

The conspicuous hiatus representing 12.4 to 11.4 m.y.B.P. and associated enhanced bottom erosion and/or dissolution might be related to a late-middle Miocene oceanic event having affected the pelagic sedimentation. A noteworthy sedimentary record of this time slice is preserved in the slumped sequence of lithologic Sub-unit 3A: it contains maximum proportions of fragmented planktonic foraminifers, fecal pellets (unique in the whole Neogene section), and pyrite. Their abundance might reflect increased fertility and organic productivity (fecal pellets are clearly related to organic carbon; Sarnthein, 1971) which was paralleled by a marked increase in $\mathrm{CaCO}$ dissolution. Although no biogenic opal has been observed in this section, the same time-slice at Site 369 contains siliceous organisms (Diester-Haass, 1978), middle-Miocene upwelling signal is inferred. The event coincides with the buildup of the eastern Antarctic ice cap (Kennett, 1977).

Apparently, rather uniform low planktonic production and high dissolution of foraminifers determined the 5 -m.y. section of lithologic Sub-units $2 E$ to $2 B$ in the upper Miocene. Although the dissolution of planktonic foraminifers (inferred from the fragmentation ratio) decreased in the Messinian Sub-unit 2B (Diester-Haass, this volume), the resulting overall hemipelagic sediment accumulation is only 153 meters, since the terrigenous input was also insignificant. A sudden drastic change towards increased pelagic sedimentation occurs at the Miocene/Pliocene boundary. The increase is associated with diminished dissolution in Sub-unit $1 \mathrm{~B}_{2} / 2 \mathrm{~A}$, from 4.9 to 3.1 m.y.B.P. (foraminifer fragmentation reduced from $50-80$ to $30-50$ per cent; Diester-Haass, this 
TABLE 1

Major Characteristics of Neogene Litho-Sub-Units

\begin{tabular}{|c|c|c|c|c|}
\hline $\begin{array}{l}\text { Lithologic } \\
\text { Sub-Unit }\end{array}$ & $\begin{array}{l}\text { Approximate Age } \\
\text { (m.y.B.P.) } \\
\text { (core depth) }\end{array}$ & General Features & $\begin{array}{l}\text { Average } \\
\text { Accumulation } \\
\text { Rates } \\
\text { (m/m.y.) }\end{array}$ & Significant Constituent Particles \\
\hline $1 \mathrm{~A}_{2}$ & $\begin{array}{l}1,8-0,9 \\
(7-4 \text { to } 15-3)\end{array}$ & $\begin{array}{l}\text { Rapid accumulation of siliceous } \\
\text { marl ooze with increasingly strong } \\
\text { pulses of terrigenous input (from } \\
\text { downslope and eolian supply) and } \\
\text { signs of volcanic action; intensified } \\
\mathrm{CaCO}_{3} \text { dissolution }(2,4)\end{array}$ & 90 & $\begin{array}{l}\text { Increasing pulses of terrigenous quartz and (bio- } \\
\text { tite) mica from bottom to top of the sub-unit (1, } \\
\text { 2); abundant volcanic fraction in lower and upper- } \\
\text { most parts of the sub-unit }(1,2) \text {; stained-quartz } \\
\text { proportion generally lower, with strong pulses of } \\
\text { unstained quartz; major pulse of glauconite in } \\
\text { lower part of the sub-unit }(1,2) \text {; abundant plant } \\
\text { fibers }(1) \text {; maximum of fragmented planktonic } \\
\text { foraminifers }(2) \text {; several pulses of abundant mixed- } \\
\text { layer clay; maximum abundance of biogenic opal } \\
(1,2)\end{array}$ \\
\hline $1 \mathrm{~B}_{1}$ & $\begin{array}{l}3,1-1,8 \\
(15-4 \text { to } 23, \mathrm{CC})\end{array}$ & $\begin{array}{l}\text { Onset of siliceous marl ooze deposi- } \\
\text { tion with ephemeral pulses of ter- } \\
\text { rigenous input, partly by turbidite } \\
\text { activity (2) (?) near the base of the } \\
\text { sub-unit }\end{array}$ & $54-74$ & $\begin{array}{l}\text { Continued high stained-quartz proportion (up to } \\
>50 \%) \text { of slightly increasing terrigenous fraction } \\
>40 \mu \mathrm{m}(1,2) ; \text { increasing appearance of volcanic } \\
\text { particles }>63 \mu \mathrm{m}(1,2) \text {; abundant pyrite }(1,2) ; \\
\text { continued dominance of planktonic foraminifers } \\
\text { in sand fraction; fragmentation at } 30-60 \%(2) ; \\
\text { common biogenic opal in coarse fraction }(1,2) \text {; } \\
\text { maximum of chlorite and illite in the upper sub- } \\
\text { unit (3) }\end{array}$ \\
\hline 2B & $\begin{array}{l}6,1-4,9 \\
(42-1 \text { to } 46, C C)\end{array}$ & $\begin{array}{l}\text { Continue slow marl-ooze deposition } \\
\text { is characterized by distinct supply } \\
\text { pulsed of coarse-grained terrigenous } \\
\text { sediment (?Messinian events); maxi- } \\
\text { mum of calcium carbonate fraction } \\
\text { (up to } 80 \% \text { ) }\end{array}$ & 36 & $\begin{array}{l}\text { Pulses of increased quartz abundance in the coarse } \\
\text { silt and sand fractions }(1,2) \text {; distinct maximum of } \\
\text { mica (biotite) in sand fraction }(1) \text {; increased } \\
\text { abundance of glauconite }(1,2) \text {; increasing propor- } \\
\text { tions of smectite and chlorite }(3) \text {; reduced frag- } \\
\text { mentation of planktonic foraminifers (mostly } \\
(50 \%)(2,4)\end{array}$ \\
\hline $2 \mathrm{C}$ & $\begin{array}{l}7,2-6,1 \\
(47-1 \text { to } 50, C C)\end{array}$ & $\begin{array}{l}\text { Same facies as Sub-unit } 2 \mathrm{E}: \text { almost } \\
\text { no terrigenous particles in the } \\
\text { coarse silt and fine sand fractions } \\
(1,2) \text {; high } \mathrm{CaCO}_{3} \text { content despite } \\
\text { high carbonate dissolution }(2,4,5)\end{array}$ & 36 & $\begin{array}{l}\text { High stained-quartz proportion of (minute) } \\
\text { terrigenous-sand fraction }(1,2) \text {; continued high } \\
\text { fragmentation of planktonic foraminifers }(1,2) \text {; } \\
\text { maximum abundance of kaolinite }(3)\end{array}$ \\
\hline $2 \mathrm{C}$ & $\begin{array}{l}8,3-7,2 \\
(51, \mathrm{CC} \text { to } 54, \mathrm{CC})\end{array}$ & $\begin{array}{l}\text { Continuation of slow marl-chalk } \\
\text { deposition; separation from Sub- } \\
\text { unit } 2 \mathrm{E} \text { by sudden appearance of } \\
\text { coarse-grained terrigenous input; } \\
\text { strong } \mathrm{CaCO}_{3} \text { dissolution }\end{array}$ & $20-36$ & $\begin{array}{l}\text { Abundance peaks of glauconite and (mainly un- } \\
\text { stained) quartz in the coarse silt and sand fraction } \\
(1,2) \text {; abundant mixed-layer clay minerals }(3) \text {; } \\
\text { minor abundances of plant fibers }(1) \text {; abundance } \\
\text { maximum of pyrite }(1,2) \text {; maximum of fragment- } \\
\text { ed planktonic foraminifers }(1,2) \text {; abundance of } \\
\text { benthic foraminifers }(2)\end{array}$ \\
\hline
\end{tabular}


TABLE 1 - Continued

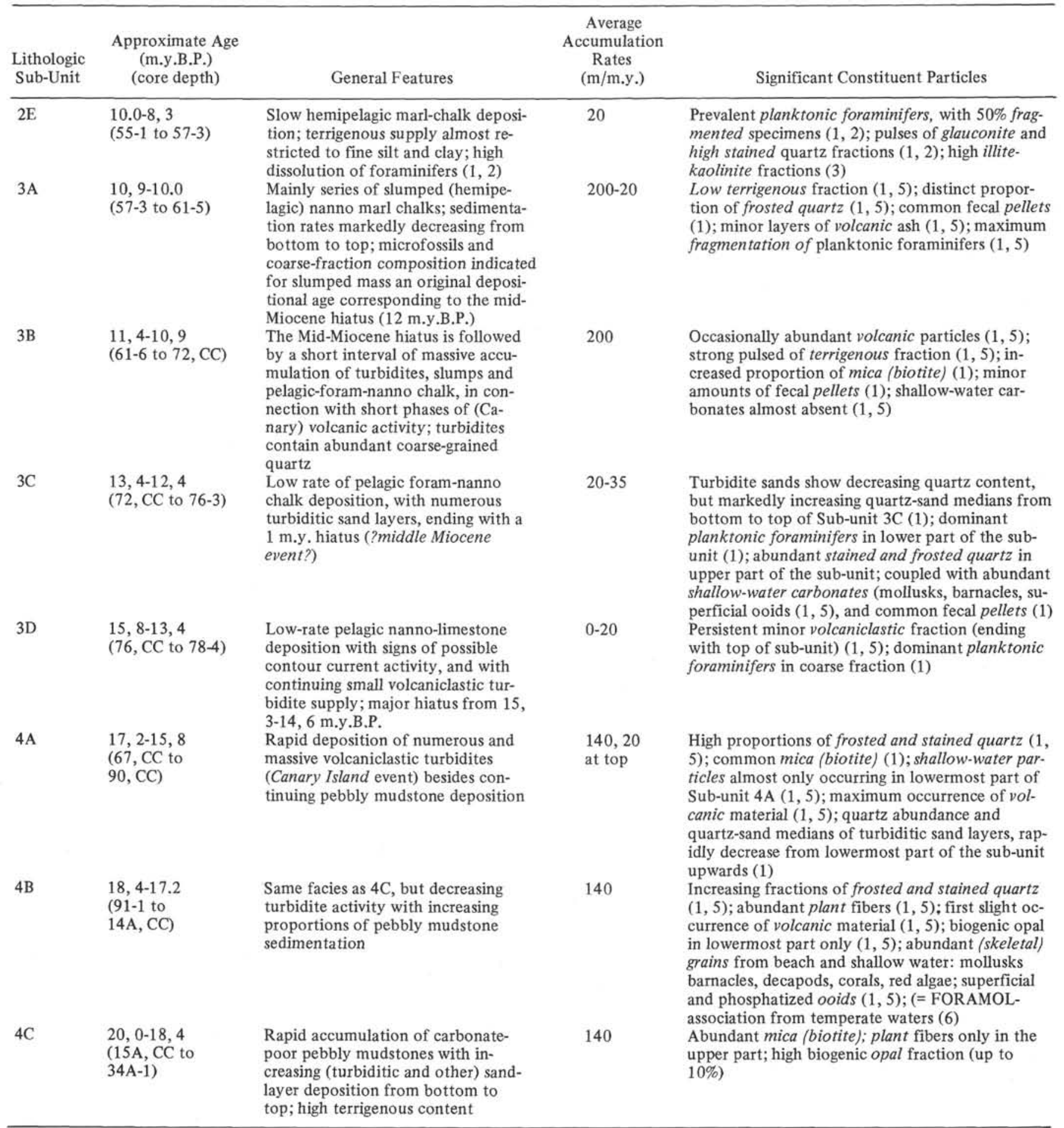

Note: Cited literature: $(1)=$ Own data (Sarnthein in Site Chapter, this volume), $(2)=$ Diester-Haass (this volume); $(3)=$ Chamley and DiesterHaass (this volume); $(4)=$ Cita and Spezzibottiani (this volume); $(5)=$ Sediment Summary Chart 1 (Site Chapter, this volume); $(6)=$ Lees, 1975 . 
volume), with continued low terrigenous input, and probably also with an increase of planktonic productivity Although rarely observed in the coarse fraction, biogenic opal occurs in smear-slide estimates from Core 397-31 upward; this supports the concept of increased pelagic productivity. The change towards higher sedimentation rates at $5 \mathrm{~m}$.y.B.P. is further marked if the N-zone stratigraphy of Cita (this volume) is used; this moves the Miocene/Pliocene boundary slightly deeper in the cores than nannofossil estimates.

The upper Pliocene-Quaternary period of known glacial expansion (Sub-units $1 \mathrm{~B}_{1}$ to $1 \mathrm{~A}_{1}$ ) is reflected by conspicuous sedimentation of siliceous plankton. Fluctuations in this constituent reach a clear maximum in the lower Quaternary and decrease somewhat in Subunit $1 \mathbf{A}_{1}$. This trend is paralleled by the course of dissolution intensity as reflected by fragmentation of planktonic foraminifers (Diester-Haass, this volume). It is also seen in maximum average accumulation rates. These maxima generally precede the strong increase of terrigenous input during the Quaternary and therefore are related to high carbonate production. Thus, it is inferred that the upwelling intensity culminated during the early Quaternary. This induced maximum fertility and was responsible for both high siliceous and carbonate production, as well as for high $\mathrm{CaCO}_{3}$ dissolution due to increased deposition and decay of organic carbon.

The detailed relation of short-term upwelling fluctuations and pulses in climate is rather complicated as shown in the detailed investigation of an upper Pleistocene reference section by Lutze et al. (this volume). These authors found that upwelling peaks partly recede or succeed major glacial phases but generalizations are difficult to make at this time.

\section{Pulses of Terrigenous and Shallow-Water Sediment Input}

Sea-level fluctuations, associated climatic changes, earthquake activity (mainly in connection with the activity of the Canary volcanism), and over-steepening of the continental slope were probably the major controling factors over the non-pelagic sediment supply. According to Figure 14, terrigenous pulses are recognizable only in the sand fraction (and generally, in the total sediment) of some 5 or 6 short segments in the Neogene: from 20 to 15.8 m.y.B.P. (Sub-units $4 \mathrm{C}$ to $4 \mathrm{~A}$ ), from 12.8 to 11.0 m.y.B.P., immediately before and after the upper-middle Miocene hiatus (Sub-units 3B and upper $3 \mathrm{C})$, during two intervals in the upper Miocene at 8.3-7.2 and 6.1-4.9 m.y.B.P. (i.e., in the Messinian; Sub-units 2D and 2B). The last major terrigenous peak began at 1.3 m.y.B.P. after smaller precursor events beginning in the middle Pliocene (Sub-unit $1 \mathrm{~B}_{1}$ ).

The lower Miocene events responsible for the conspicuous supply of terrigenous material in lithologic Unit 4 , have been discussed extensively in the previous two sections. Both a major fluctuation in sea level and climate, as well as a renewed phase of Canary Island volcanism with associated earthquakes, might have caused the strong and short terrigenous pulse in the upper-middle Miocene, where a major part of the terrigenous supply was deposited from turbidity currents.
Volcanic ash layers are known from the contemporary section of neighboring slope Site 369 (Cores 369A-3 and 369A-4, NN 9; Diester-Haass, 1978). On one hand, the model of an enhanced volcanic earthquake event as control receives support from the sudden occurrence of volcanic particles in Sub-unit 3B (Figure 14) and from the Canary Island record itself, where a significant volcanic phase is described from exactly the same stratigraphic position (see Figure 12; Schminke, 1976). On the other hand, a drastic sea-level and climatic fluctuation around 11 to 12 m.y.B.P. likewise forms a meaningful explanation for the increase of terrigenous input. It seems to be concomitant with an upwelling event previously discussed. Furthermore, it appears to be correlative with a contemporarily occurring eoliansand turbidite in Site 140 (Sarnthein, 1978a), a sediment facies which is related to lowered sea-level close to the shelf break, aridity, and prevailing offland winds (Sarnthein and Diester-Haass, 1977). Because of erosion and insufficient stratigraphic resolution, the land record (e.g., Ratschiller, 1970) cannot contribute much to this interpretation.

The late Miocene, Pliocene, and Quaternary phases of enhanced terrigenous input appear more clearly related to outstanding climatic and sea-level events. The Messinian (Sub-unit 2B, Figure 14) is as well-known for its lowered shorelines and climatic deterioration (e.g., Ryan et al., 1974; Shackleton and Cita and Cita and Ryan, both this volume) as the Quaternary. Sub-unit 2D presents an analogous earlier environmental event at some 8.3 to 7.2 m.y.B.P.: a new result of this study. A few turbidites at the base of Sub-unit $1 B_{1}$ (DiesterHaass, this volume) are probably associated with a midPliocene cooling-glaciation event (Berggren and van Couvering, 1974; Cita, 1973; Shackleton and Cita, this volume) and its influence on sea-level lowering. A stillquestionable hiatus (Cita and Ryan, this volume) might indicate increased bottom erosion immediately below the turbidites and thus underlines the significance of the event. The same holds true for a possible stratigraphic gap which proceeds the major Quaternary terrigenous pulses at 1 to 2 m.y.B.P. Also volcanic events (ash layers) mark the lower Quaternary of Sub-units $1 \mathrm{~A}_{1}$ and $1 \mathrm{~A}_{2}$, but they do not directly coincide with the enhanced terrigenous supply. A slumping event during the late Pleistocene oxygen isotopic Stage 5 appears directly related to sudden volcanic sediment supply and probably to associated earthquakes (Lutze et al., this volume).

The fluctuations in terrigenous supply can easily be attributed in broad outlines to significant environmental events. However, it is far more complicated to ascribe the origin of a certain terrigenous fraction to downslope transport from the shelf, eolian dust discharge, or fluvial sediment input. For example, displaced species of shallow-water benthic foraminifers serve as tracers. They demonstrate that the downslope transport of sediments amount up to one-third of the deposited material at Site 397. The same apparently applies during cold and warm stages of the late Pleistocene (Lutze et al., this volume). 
Deep-Sea Record of Climatic Change and Desertification in Africa

In addition to bedrock composition, the history of North African continental climate, sea-level, and vegetational cover appears as the primary controlling factor over amount and composition of terrigenous input at the eastern Atlantic continental margin.

A somewhat detailed land record exists only within the range of ${ }^{14} \mathrm{C}$ dating. During the past 30,000 years, African subtropical deserts have gone through several short-lived but basic changes of position and extent, reaching a maximum during the last glacial maximum and almost vanishing during the last climatic optimum (Sarnthein, 1978b). Transitional stages display further complicated (dominantly humid?) fluctuations. More ancient land evidence becomes progressingly scarce with increasing age because of insufficient opportunities to precisely date terrestrial sections and because of multiple erosion events. The first erosional event preceded the early Miocene and was related to a major regression (Dillon and Sougy, 1975). The overlying widespread "Continental Terminal" represents most of the Neogene ( 15 to $20 \mathrm{mly}$.) in the southern Sahara and Sahel zone, south of $18^{\circ}$ to $23^{\circ} \mathrm{N}$. Its thin (< to $100 \mathrm{~m}$ ) continental detritic sediments of fluvial and lacustrine origin, and its intermittent conspicuous lateritic iron crusts testify to an extensive period of warm-humid tropical climate (Michel, 1973). According to the palinspastic reconstructions of Francheteau (1970), northern Africa shifted some $6^{\circ}$ to the north (away from the equator) during this interval. A few lignitic clays and kaolinic sands might indicate interesting, but on land, undatable, climatic fluctuations (more humid and arid excursions) which took place sometime in the middle Miocene. Another (intermittent aridity signal is bound to a marked regression and, therefore, might correspond to approximately the Miocene/Pliocene boundary. Only in the middle and late quaternary did Sahara desert sands and associated aridity spread south over Mauritania and Senegal to about $10^{\circ}$ to $14^{\circ} \mathrm{N}$ (Michel, 1973).

The northwestern Sahara Neogene (see Conrad, 1969) consists of widespread undifferentiated lacustrine (siliceous and carbonate) sediments which also provide evidence for a generally humid Neogene climate. The series ends with an erosional level somehow associated with a middle Pliocene event, possibly also to the regression at the Miocene/Pliocene boundary. Thin Miocene coastal calcareous sandstones from the northwestern Sahara margin (Aaiun Formation) remain undifferentiated as well (Ratschiller, 1970). Within the upper Pliocene (?), the most extensive and thick fresh-water deposits (fish shales and fluviatile sediments) from the Atlas and Hoggar Mountains again prove humid subtropical conditions. The "Plio-Villafranchian" series is finally covered by carbonate and evaporite crusts associated with dune deposits. They correspond to a drastic change towards aridity approximately at the base of the Quaternary (Conrad, 1969). After this, the Villafranchian pluvial lakes seem to occur again in the northwest, and tropical lateritic Fe crusts locally occur even north of the Air-Hoggar Mountains during the early Quaternary. The middle and upper Quaternary deposits are characterized by a succession of lake sediments and calcareous (in the north) and ferrugenous (in the south) crusts alternating with desert deposits (Conrad, 1969).

In summary, the Neogene land record shows that also in the northwestern Sahara generally humid, subtropical conditions prevailed. These conditions appear to deteriorate along recognizable steps to the frequent late Pleistocene climatic fluctuations which exhibit marked aridity.

Continental climate and the deep-sea record of Site 397 are linked by the terrigenous input of rivers, eolian dust, and offland advancing eolian dune sands.

A dune sand source is only suggested to explain the source environment of some quartzose turbidites and quartzose pebbly mudstones in Sub-units $3 \mathrm{~A}$ and $4 \mathrm{~A}$, where fine- to medium-sized, frosted quartz sand is abundant and associated with shallow-water skeletal grains (Figure 14). For this time from about 17.5 to 16 m.y.B.P. aridity with associated sand dunes might be inferred (? on the Canary Isles), and during the hiatus event at 12 m.y.B.P. (on the African continent).

The unequivocal distinction of direct wind-dust discharge sediment from laterally supplied river sediment out of semiarid zones remains somewhat problematic (Site 397 Report; Diester-Haass; both, this volume). Following the climatically calibrated sedimentary record of "Meteor" Core 12309 near Site 397 (Lutze et al., this volume), fluviatile sediments are characterized mainly by a high fraction of plant debris, high clay content (e.g., Senegal River; Lange, 1975), and the presence of limonitic silitite particles (Kiper, 1977). Little conclusive evidence of fluvial input is found during the late Pleistocene climatic stages, and wind-dust transport of silts appears to be the main source of terrigenous sediment besides downslope turbid layer transport or shelf spillover (probably also reworking eolo-marine sediment). Plant fibers become markedly abundant only in lower Quaternary Sub-unit $1 \mathrm{~A}_{1}$ (Figure 14). They may reflect the increased upper Villafranchian humidity which was probably associated with early phases of lowered sea level (peaks in amount of shelf-eroded glauconite). Other occurrences of plant debris and fluviatile supply appear in lower Sub-unit 2D (8.3 to 7.9 m.y.B.P.) and are more pronounced in Subunits $4 \mathrm{~B}$ and $4 \mathrm{C}$ (upper-lower Miocene, 19.2 to 17.2 m.y.B.P.).

The wind-dust supply from northern Africa is not directly indicative of arid or humid climates, desert or nondesert source areas. Its characteristic atmospheric trajectory at $>1500$-meter altitude can originate from either fully arid or from semiarid zones showing only intermittent, e.g., seasonal droughts (for example, savannahs). A basic condition providing energy for the formation of large-scale dust clouds is a zone of rising air cells such as occur along the Intertropic Convergence Zone (ITCZ) in the Sahel belt (Rognon, 1976) or within troughs of the Westerlies at the present northern Sahara 


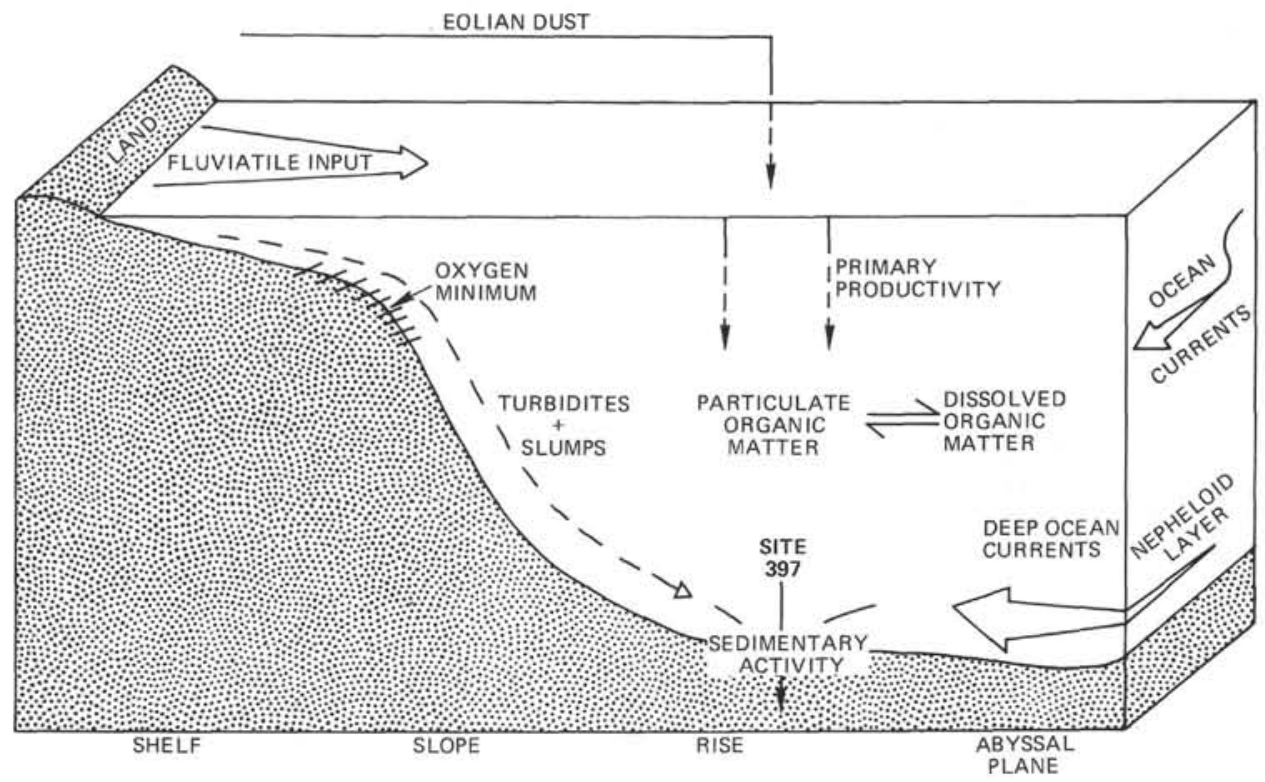

Figure 15. Factors affecting the organic matter content of shelf, slope, and rise sediments (source-redistribution-preservation). After Cornford (this volume, fig. 1).

margin. Accordingly, the grain sizes and composition of marine wind-dust deposits can reflect dominating specific source areas and length of trajectory, or wind vigor, and thereby disclose the position of main meteorological systems and climatic regimes.

At Site 397 (Figure 14) the presumably dust-derived sediments clearly subdivide into two different facies (Lutze et al.; Diester-Haass; Chamley and DiesterHaass; all, this volume). The first type is fine-silt sized and contains a highly stained (reddish) quartz proportion, abundant hematite, kaolinite, mixed layer clay minerals, and smectite. Dust collections of Chester et al. (1972) in this region show that this type of dust is practically devoid of carbonate. The second type contains coarse-silt and some fine-sand sized, unstained quartz; abundant biotite; some obviously detrital carbonate; and enhanced chlorite, illite, and palygorskite (a composition similar to modern dust off Cape Blanc; (Koopman et al., in press; Lange, 1975). As a result of the previously discussed north-south zonation of the sedimentary cover in Africa, the first dust type is likely to have been derived from the southern Sahara and Sahel lateritic belt; the second type, from the northern Saharan calcareous and siliceous zones.

Thus, the deep-sea record at $27^{\circ} \mathrm{N}$ off the present northern Sahara reveals two atmospheric trajectory systems. One system supplies the dust over far distances from southern savannah regions which are basically humid during the summer monsoonal season and dry in the winter. Almost no material from the northern Sahara is added because of anticyclonic (i.e., falling) winds mainly parallel to the shoreline. Such a regime occurs during warm Pleistocene climatic stages (e.g., Shackleton and Cita, this volume) as well as during long-term warm intervals of the Neogene. During warm stages, the moisture-furnishing ITCZ extended across the (modern-day) Sahara some $5^{\circ}$ to $15^{\circ}$ farther north than during the cold phases, but also farther than in the present late-Holocene situation (Sarnthein, 1978b). This is particularly apparent, when one considers an additional $6^{\circ}$ of northward continental drift since the early Miocene (compare Sarnthein, 1978a).

The alternate trajectory system probably transported dust on a much shorter straight line (further shortened by emergent shelves) from the northern Sahara to the ocean. This is characteristic of the weather regime during the glacial extremes of the Pleistocene (and Neogene) cold stages, when Saharan aridity was widespread, between $10^{\circ}$ and $35^{\circ} \mathrm{N}$ (Sarnthein, 1978b). During these times, ascending cyclonic cells of the Westerlies shifted south to northern Africa without carrying abundant moisture (Rognon, 1976), the vigor of the wind system apparently was increased (Manabe and Hahn, 1977), and sea level was low.

As summarized in Figure 14, this glacial-type northern dust regime might best explain the average terrigenous sediment input during the late and middle Pleistocene, the latest Pliocene, the Messinian, and the upper Tortonian (about 7.2 to 8.0 m.y.B.P.). This regime might have also occurred during the hiatus-forming event at 12 m.y. B.P. (preserved record in the slump of Sub-unit $3 \mathrm{~A}$ ) during the main Canary event at 16 to 17.5 m.y.B.P. and during the early Miocene to Hauterivian hiatus (Sites 138, 139; Sarnthein, 1978a). The remaining part of the Neogene environmental history resembles the mid-Holocene humid (winter-dry) situation with important consequences for the north-south exchange of continental faunas. This climatic record is consistent with the land record and with the results from the other sites at the African eastern Atlantic continental margin 
(Sarnthein, 1978a; Diester-Haass, 1978, reinterpretation).

\section{PETROLEUM POTENTIAL OF THE CAPE BOJADOR MARGIN (U.v.R., C.C., M.A.A.)}

\section{Introduction}

Thick Mesozoic carbonates and Cretaceous to Cenozoic sediment wedges underlying the continental slopes and upper rises of Atlantic-type margins are one of the last frontiers in the future search for offshore hydrocarbons (Hedberg, 1970; Thompson, 1976). Since the accumulation of hydrocarbons requires a mature source rock, a migration pathway, and a trap, the best reserves will probably be found in those basins which combine deep burial (or shallower burial compensated by a high geothermal gradient) of source rocks rich in marine organic matter, interfingering of permeable beds for migration, and reservoir formation with promising structural or stratigraphic traps.

The total sediment fill of the Cape Bojador marginal basin (on- and offshore part, see von Rad and Einsele, in press) can be very roughly estimated at a volume of 1.5 to 2.0 million $\mathrm{km}^{3}$. This considerable volume is similar to that estimated for the Gabon-Angola Basin and ranges between the smaller "Morocco Basin," onshore and offshore parts of the Senegal Basin and the Niger Delta (P. Lehner, personal communication). Since the axis of the "Cape Bojador marginal basin" or "marginal geosyncline" (Beck and Lehner, 1974) is about $100 \mathrm{~km}$ offshore, more than two-thirds of the basin occupies the present slope and upper rise which overlies continental to transitional crust.

\section{Source Rocks}

Several times in its history, the Cape Bojador Basin accumulated organic-rich sediments:

1) During early Neogene times, large amounts of organic-rich mudstones, originally deposited in an oxygen-depleted zone on the upper slope (Lithofacies F-3; Arthur and von Rad, this volume), underwent rapid downslope transport by mass flows into the welloxygenated upper rise (Figure 15). Here, because of rapid burial, they escaped the degradation of planktonic organic matter, normally encountered in an oxidizing environment (Cornford, this volume; see fig. 16). This is an important mechanism for source rock deposition in the rapidly deposited flyschoid sediments of the upper continental rise. In addition, similar Miocene sediments rich in marine organic matter should exist "in place" on the upper continental slope. This concept, the mapping of sediments deposited in, or transported from a paleo-oxygen-minimum zone, may become of prime importance in the search for hydrocarbons in the outer continental margins. Some initial paleoceanographic reconstructions have been attempted (Thiede and van Andel, 1977; Fischer and Arthur, 1977) and are currently being refined by an increasing number of authors synthesizing DSDP results. In the shelf well Spansah 51A-1 (Figure 3), marly shallow-water limestones of Santonian to Maestrichtian age have a generally good source-rock potential with good porosities. Although these sediments were saturated by indigenous oil with 70 per cent asphaltenes, they have very low permeabilities (CONOCO, 1969).

This late Neogene hemipelagic sediments at Site 397 are rich in biochemical methane and were deposited under high fertility (upwelling) conditions. Cornford (this volume) argues that much of the planktonic organic matter is normally lost at or immediately under the sediment interface leaving a kerogen (sedimentary organic matter) enriched in the more resistant degraded humic component of terrestrial plant origin. Large amounts of terrestrial organic matter were introduced into the deep ocean during periods of humid climate, when peats and swamps supported an abundant vegetation (Tissot, 1978).

Analysis of the light hydrocarbons (Whelan, this volume) suggests that the methane is of biogenic (bacterial) origin as indicated by $\delta^{13} \mathrm{C}$-values of $-60 \%$ to $-80 \%$ with the probability of clathrates down to $45^{\circ}$ meters. It is argued that the "in-phase" fluctuation of the light hydrocarbon ratios indicates an absence of vertical migration (Whelan, this volume). Combining the conclusions of Whelan (this volume) and Cornford (this volume) the bacterial degradation of the planktonic organic component may produce methane which, with rapid sedimentation, remains trapped in the sediment. This source of early "diagenetic" methane may also be of importance when estimating the source rock potential of other pelagic or hemipelagic sediments; these sediments were accumulated under oxidizing conditions at the sea floor underlying an area of high surface bioproductivity.

2) Mid-Cretaceous (Aptian to early Turonian), or ganic-rich shales and marls are present in the AaiunTarfaya Basin (Einsele and Wiedmann, 1975), in the shelf well Spansah 51A-1 (Figure 3) and at DSDP Site 369 (Lancelot, Seibold, et al., 1978): rocks of this age were eroded at Site 397 and presumably in adjacent areas of the lowermost slope and upper rise. Black Late Cretaceous shales, rich in hydrocarbons have also been described from the onshore Gaada Formation (AUXINI, 1969). The origin of the black shales in the onshore area has been explained by basinwide stagnation, an expanded mid-water oxygen minimum and/or an increase in coastal upwelling (e.g., Ryan and Cita, 1977; Fischer and Arthur, 1977; Einsele and Wiedmann, 1975).

3) Early Cretaceous - Site 397 and the shelf well Spansah 51A-1 penetrated thick Early Cretaceous prodeltaic to deltaic (lagoonal to intertidal) sediments which are rich in residual land-derived higher plant debris of humic composition. The potential of such sediments to act as liquid hydrocarbon source rocks depends on their content of the more hydrogen-rich tissues such as cuticles, spores, and resins. The sediments at Site 397 did not show unusually high contents of such particles, but lateral variation may be expected in a deltaic setting (Table 2). The gas potential of such sediments depends mainly on maturity (see below).

4) The Jurassic-Triassic interval may contain hydrocarbon source rocks accumulated under restricted circu- 
TABLE 2

Summary of Source Rock Characteristics and Their Interpretation in Terms of the Hydrocarbon Prospects for the Five Lithostratigraphic Units, DSDP Site 397

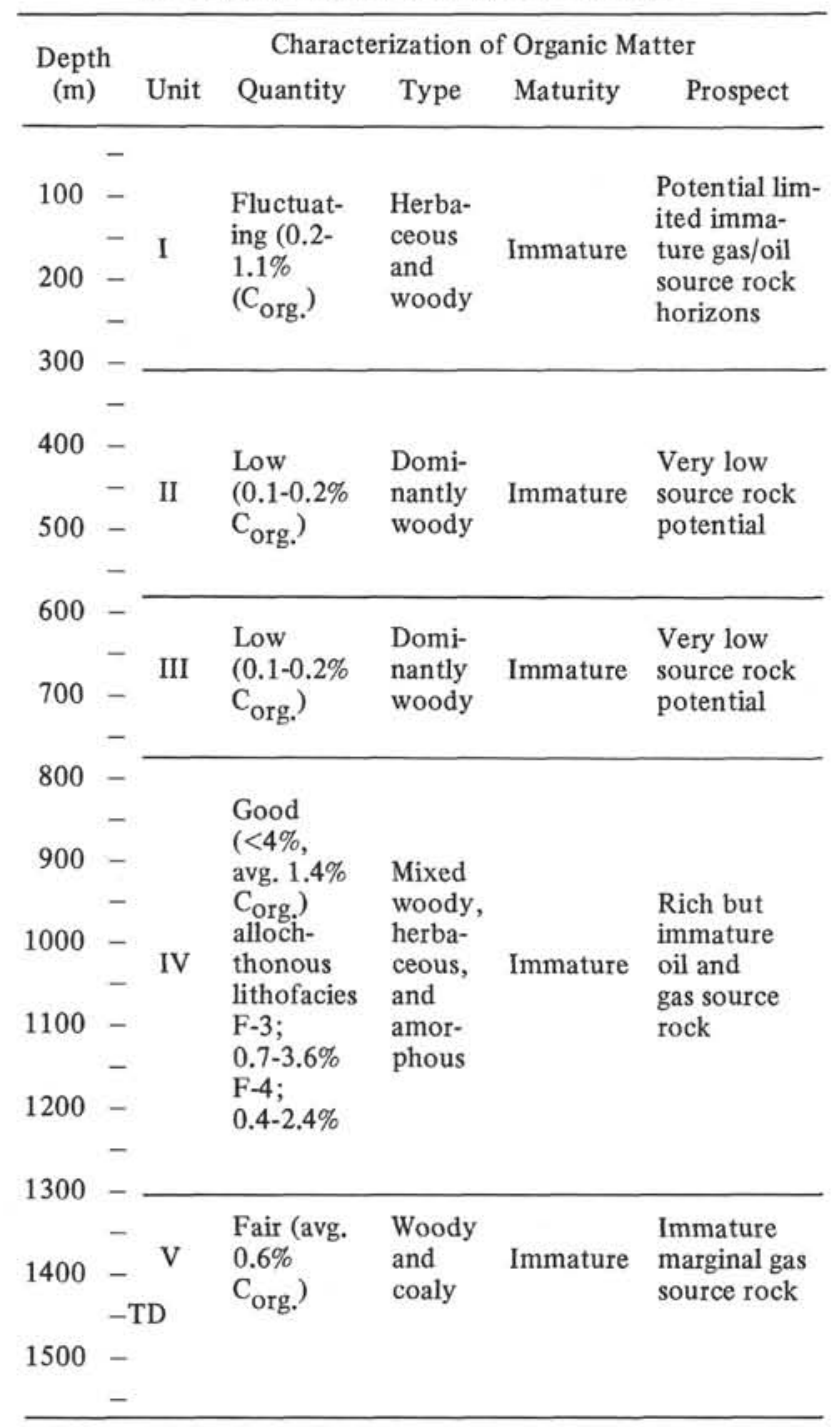

lation conditions in troughs formed by basement block faulting during a Triassic-Liassic early rift stage. By analogy with the restricted basins of the Early Cretaceous South Atlantic (Thiede and van Andel, 1977), good quality source rocks might be expected to accumulate.

\section{Maturation}

The maturation of organic matter is essentially a temperature-controlled process although, for very short burial times, time plays a major role (Connan, 1974). The geothermal gradient at Site 397 (estimated at about $40^{\circ} \mathrm{C} / \mathrm{km}$ ) appears to be about 1.5 times higher than in comparable mature passive continental margin settings (Scotian Shelf Basin $24^{\circ} \mathrm{C} / \mathrm{km}$, Niger Delta $28^{\circ} \mathrm{C} / \mathrm{km}$, southern North Sea $34^{\circ} \mathrm{C} / \mathrm{km}$; Scholle, 1977), although thermal data from oil wells should not be directly correlated with heat flow measurements from the upper- most ten meters of the sea floor sediment. The heat flow anomaly in the Canary Island area gives rise to a shallower top for the petroleum-generating zone.

Organic maturity can be measured using vitrinite reflectance (see Table 2). Pearson and Dow (this volume), taking the onset of oil generation at the $>0.6$ per cent reflectance level, predict the start of effective generation at 1870 meters below the sea floor. These authors also predict that the top of significant wet gas formation $(>0.8 \% \mathrm{R})$ lies at about 2300 meters below sea floor at Site 397. In general, these data agree with the maturity data of Deroo et al. (this volume) and Kendrick et al. (this volume). They show that the entire section penetrated at Site 397 is immature with regard to petroleum formation, the Cretaceous bottom-hole sediments being on the verge of the "initial maturity" stage (Table 3 ).

In the much "cooler" Baltimore Canyon Trough off New Jersey (U.S.A.), a geothermal gradient of only $26^{\circ} \mathrm{C} / \mathrm{km}$ gives rise to a reflectance level of 0.6 per cent $\mathrm{R}$ at 3700 meters below sea floor (Scholle, 1977).

The regionally high geothermal gradient and heat flow (Herman et al., 1977) is probably an effect of the mid-Tertiary evolution of the Canary Islands volcanic center which is about contemporaneous with the upcoming volcanic intrusion of the Cape Verde Rise (Site 368; see Lancelot, Seibold, et al., 1978). Since the high heat flow in the region dates only from the midTertiary, a time effect on petroleum generation may be invoked. This means that for short effective burial (and hence heating) times, higher temperatures are required to reach a given stage of petroleum generation (Connan, 1974). For an effective heating time of $10 \mathrm{~m} . \mathrm{y}$. (which with continuous sedimentation covers a $20^{\circ} \mathrm{C}$ rise in temperature; the uppermost $500 \mathrm{~m}$ at Site 397 were deposited at $50 \mathrm{~m} / \mathrm{m} . \mathrm{y}$. under a gradient of $40^{\circ} \mathrm{C} / \mathrm{km}$ ), Hood et al. (1975) estimate the onset of petroleum generation to occur at about $100^{\circ} \mathrm{C}$. This compares with a projected temperature of about $65^{\circ} \mathrm{C}$ at total depth for Site 397.

According to Cornford (this volume), the early Miocene Unit 4 contains reasonable quantities (average $1.4 \% \mathrm{C}_{\text {org }}$ ) of mixed, but generally liptinite-rich organic matter, which has a good potential for oil and wet gas formation. In contrast, the Hauterivian pro-delta mudstones contain mainly woody, higher plant organic matter, transported from the continent and, therefore, having only a potential for gas generation at higher maturities (Cornford, this volume, table 3 ).

The maturation of organic matter at Site 397 is complicated by the major erosional hiatus of about $100 \mathrm{~m} . \mathrm{y}$. at 1300 meters between the lower Miocene and the Hauterivian, in addition to the probable change in the geothermal gradient in the Tertiary. The Hauterivian sediments have undergone the sequence of deposition: burial-erosion-burial. This cycle complicates the detailed interpretation of the maturation and thermal history (see Organic geochemistry synthesis, Cornford, this volume). Since the increase in the reflectance of vitrinite is an il reversible process, the absence of a significant 
TABLE 3

Summary of Some Shore-Based Organic Geochemical Studies

\begin{tabular}{|c|c|c|c|c|}
\hline \multirow[b]{2}{*}{ Authors } & \multicolumn{3}{|c|}{$\begin{array}{c}\text { Type of Organic Matter/Maturity } \\
\text { Section/Depth }\end{array}$} & \multirow[b]{2}{*}{ Methods } \\
\hline & $\begin{array}{l}\text { Pleistocene/Pliocene } \\
\quad(0-540 \mathrm{~m})\end{array}$ & $\begin{array}{l}\text { Miocene }(540-1300 \mathrm{~m}) \\
\text { Autochthonous/Allochthonous }\end{array}$ & $\begin{array}{c}\text { Cretaceous } \\
(1300-1450 \mathrm{~m})\end{array}$ & \\
\hline Dow and Pearson & & $\begin{array}{l}\text { Dominantly amorphous/ } \\
\text { immature; smaller amounts } \\
\text { woody }\end{array}$ & $\begin{array}{l}\text { Predominantly } \\
\text { woody/immature; } \\
\text { smaller amounts } \\
\text { amorphous }\end{array}$ & $\begin{array}{l}\text { Microscopy; vitrinite } \\
\text { reflectance }\end{array}$ \\
\hline Tissot & & $\begin{array}{l}\text { Marine Type II; kerogen } \\
\text { (planktonic algae, etc.); } \\
\text { immature }\end{array}$ & $\begin{array}{l}\text { Continental } \\
\text { (woody); } \\
\text { immature }\end{array}$ & $\begin{array}{l}\text { Extraction } \\
\text { humic and kerogen } \mathrm{H} / \mathrm{C} \\
\text { and } \mathrm{O} / \mathrm{C} \text { ratios, Pyrolysis }\end{array}$ \\
\hline $\begin{array}{l}\text { Kendrick, Hood, and } \\
\text { Castaño }\end{array}$ & & $\begin{array}{l}\text { Lower Miocene best source } \\
\text { rocks }\end{array}$ & $\begin{array}{l}\text { Low content; } \\
\text { not reactive }\end{array}$ & $\begin{array}{l}\text { Organic Carbon } \\
\text { pyrolysis flow, } \\
\text { vitrinite microscopy, } \\
\text { (not good source rocks) }\end{array}$ \\
\hline $\begin{array}{l}\text { Johnson, McIver, and } \\
\text { Rogers }\end{array}$ & $\begin{array}{l}\text { Amorphous/herbaceous/ } \\
\text { immature (org. lean) }\end{array}$ & $\begin{array}{l}\text { Mainly herbaceous; smaller } \\
\text { amount amorphous/ } \\
\text { immature (more org. } \\
\text { present) }\end{array}$ & $\begin{array}{l}\text { Mainly woody; } \\
\text { some herbaceous; } \\
\text { immature }\end{array}$ & $\begin{array}{l}\text { Extraction: organic } \\
\text { Carbon; microscopy }\end{array}$ \\
\hline Erdman and Schorno & Immature & Immature & Immature & $\begin{array}{l}\text { Extraction/GC of alkanes, } \\
\text { lipid } \mathrm{SC}_{13} \text {; organic carbon/ } \\
\text { nitrogen content }\end{array}$ \\
\hline $\begin{array}{l}\text { Cornford, Rullkottes, and } \\
\text { Welte }\end{array}$ & Higher plant & $\begin{array}{l}\text { Predominantly higher } \\
\text { plant, some amorphous }\end{array}$ & Higher plant & $\begin{array}{l}\text { Microscopy, } \\
\text { extraction/GC of alkanes }\end{array}$ \\
\hline
\end{tabular}

"jump" in the reflectance values across the unconformity at 1300 meters (Cornford et al., this volume) would, in a simple interpretation, indicate that not more than 1300 meters (Dow and Pearson, this volume, specify $360 \mathrm{~m}$ ) of overburden were deposited and eroded during the $100-\mathrm{m} . \mathrm{y}$. hiatus. But, as argued before, a geothermal gradient of $25^{\circ} \mathrm{C} / \mathrm{km}$ is more reasonable for Cretaceous-early Tertiary times. Taking this lower gradient, the vitrinite reflectance maturity data would then indicate that not more than 2 to $2.5 \mathrm{~km}$ (instead of 1.3 $\mathrm{km}$ ) were deposited and eroded during the time represented by the $100-\mathrm{m} . \mathrm{y}$. hiatus. This higher value appears to agree with the interpretation of seismic reflection profiles (Hinz; Wissmann; both, this volume), which suggest that roughly 1 to $2 \mathrm{~km}$ of sediments were eroded at Site 397 prior to the rapid deposition of the early Miocene section.

\section{Reservoir Beds}

Potential reservoir beds in the uppermost rise sequence at Site 397 are turbidite sandstone beds in the predominantly allochthonous middle to early Miocene Units 3 and 4 . In order to evaluate the potential flow direction of hydrocarbons and the direction of closure of such permeable beds, it is necessary to reconstruct the source of the sand layers, their three-dimensional geometry, and the morphology of the basin (see Arthur and von $\mathrm{Rad}$, this volume). Also the source rock potential and the distance of the source areas are of importance (see Figure 8).

Well-sorted distal turbidites of Lithofacies F-1A (Arthur and von Rad, this volume), are relatively poor reservoir rocks (100 to $1150 \mathrm{~m}$ sub-buttom) especially if cemented by calcite. Their probable longitudinal trans- port from northeast to southwest makes it probable that no updip pinchout stratigraphic closures can be expected near Site 397 . Some of the thicker turbidites (up to $3 \mathrm{~m}$ ) derived from the Cape Bojador slope have better porosities. Good porosities can be expected also from well-sorted eolomarine turbidites (Sarnthein and Diester-Haass, 1977; von Rad et al., 1978). Best porosities ( 25 to 50 per cent) were found in volcaniclastic sandstones. Assuming enough interconnected pore space, these are good values for fluid and gaseous carbon migration and reservoir potential. A problem is the clayey matrix which often inhibits the migration of fluid and gaseous hydrocarbons in the sediment. The thick volcaniclastic sandstones $(750$ to $810 \mathrm{~m}$; Lithofacies F-4B, 4 to $8 \mathrm{~m}$ thick) were in one case impregnated by comparatively high gas contents. The section between 550 and 850 meters is characterized by high contents of laterally diffusing methane (Whelan; Cornford; both, this volume). These volcaniclastic sandstones are derived from Fuerteventura and pinchout against the foot of the continental slope (Schmincke and von Rad, this volume). These turbidites or debris flow deposits may be open to horizontal updip migration of hydrocarbons in northerly to northeasterly direction (Figure 16).

\section{Hydrocarbon Traps}

In this foot-of-slope setting with very little structural disturbance, stratigraphic traps are most important for the potential retention of hydrocarbons, especially between Reflectors R-7 and R-8 (see Figure 16). They occur as updip pinchout traps of laterally derived turbidite sand or debris flows (see Arthur and von Rad, this volume); as sandstones sealed by volcaniclastic debris flows and as distal turbidites or contourites which 


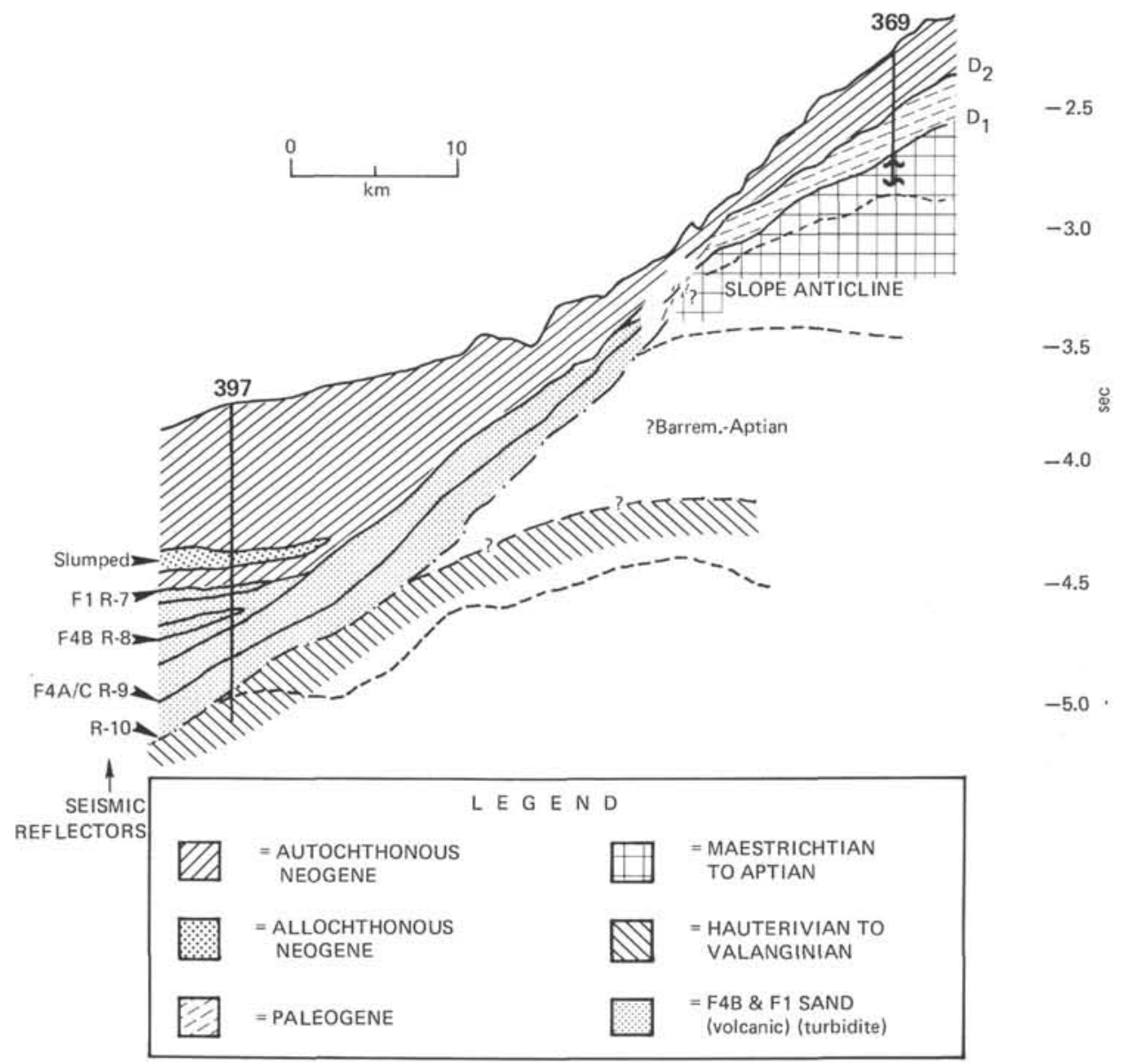

Figure 16. Cross-section of the outer continental margin northwest of Cape Bojador showing potential hydrocarbon stratigraphic or structural traps (elements of closure, such as pinchouts, unconformities; "slope anticline"). Seismic profile M25-A2 (BGR, Hannover), (modified from $O$. Weser, unpublished report, fig. 9).

pinchout towards the intermediate rise and (up current) in a longitudinal direction along the length of the southern Canary Island channel (Figure 8).

Unconformities might be of minor importance at Site 397 since they usually are not sealed effectively in an upward direction, and since the anticipated "Cenomanian" transgression $\left(D_{1}\right)$ was not encountered. The early Miocene/Hauterivian unconformity, for example, does not show any significant break in density or porosity.

In the absence of recognizable diapirism and salt tectonics, the "slope anticline" is the only major structure which might have trapped hydrocarbons (see discussion in Lancelot, Seibold, et al., 1978). This structure with its predominantly landward-dipping strata is explained here as due to differential loading and isostatic rebound, rather than to compressional tectonics.

Another type of structural trap might be the antithetic, gravitative growth faults which were seismically detected within the Early Cretaceous Wealden-type delta foreset beds below the lower and intermediate slope (see Hinz; Einsele and von Rad; Frontispiece; all, this volume).
Since only about 10 per cent of the sediment fill of the Cape Bojador marginal basin has been penetrated at Site 397 , there is still a good possibility that natural gas or petroleum was generated deeper in the basin and later migrated vertically or laterally into Mesozoic porous clastic rocks or platform carbonates.

\section{MESOZOIC-CENOZOIC SUBSIDENCE HISTORY AND PALEOBATHYMETRY (U.V.R.)}

\section{Late Triassic to Jurassic Evolution and Shallow-Water Sedimentation}

We can only speculate on the late Triassic and Jurassic early rift, drift, and subsidence stages of the 200-m.y.-old mature Cape Bojador margin. In the Aaiun (Tarfaya) Basin (Figure 1), several exploration wells penetrated 1 - to over $2-\mathrm{km}$-thick sequences of Middle to Late Jurassic shallow-water limestones, marlstones and dolomites (von Rad and Einsele, in press). In one well, located close to the eastern basin flank, coarse terrigenous clastics of middle(?) to late Triassic age overlie metamorphic basement of the Requibat Massif. Off Morocco, Late Jurassic (Oxfordian) reefal and 
shallow-water intertidal carbonates were dredged from the base of the Mazagan Plateau (Renz et al., 1975). Similar Jurassic carbonate platforms were reported from drilling and/or seismic evidence from below the shelf edges off Senegal (Lehner and DeRuiter, 1977) and off southern Morocco (Vail and Mitchum, 1978). Therefore, von Rad and Einsele (in press) postulated a thick sequence of Jurassic shallow-water limestones under the entire Cape Bojador continental margin which were deposited on a tectonically stable, slowly subsiding shelf. If we assume that the basin floor at Site 397 remained close to sea level until the earliest Cretaceous, subsidence rates equal sedimentation rates, which can be roughly calculated as $110 \mathrm{~m} / \mathrm{m}$.y. for the Jurassic at Site 397 (see Figure 17). This subsidence rate is very tentative, because it depends entirely on the geophysical interpretation which defines the base of this sequence (G. Wissmann, personal communication; see
Frontispiece). If Triassic or even late Paleozoic sediments are included (P. Lehner, personal communication), subsidence rates become considerably smaller; if sedimentation started not before the late Liassic onset of spreading (165 to 180 m.y.B.P.), they become somewhat greater.

\section{Early Cretaceous Subsidence, Sedimentation, and Paleobathymetry}

Near the Jurassic/Cretaceous boundary, a remarkable facies change from shallow-water carbonates to more or less terrigenous facies ("Jreibichat Formation") took place in the Aaiun Basin (see Figure 3). This very thick regressive sequence of continental clastics grading seaward into lagoonal, intertidal, delta plain, delta foreset, and finally into distal prodelta muds constitutes a huge Wealden-type deltaic system (see Einsele and von Rad, this volume; von Rad and Einsele, in press). The

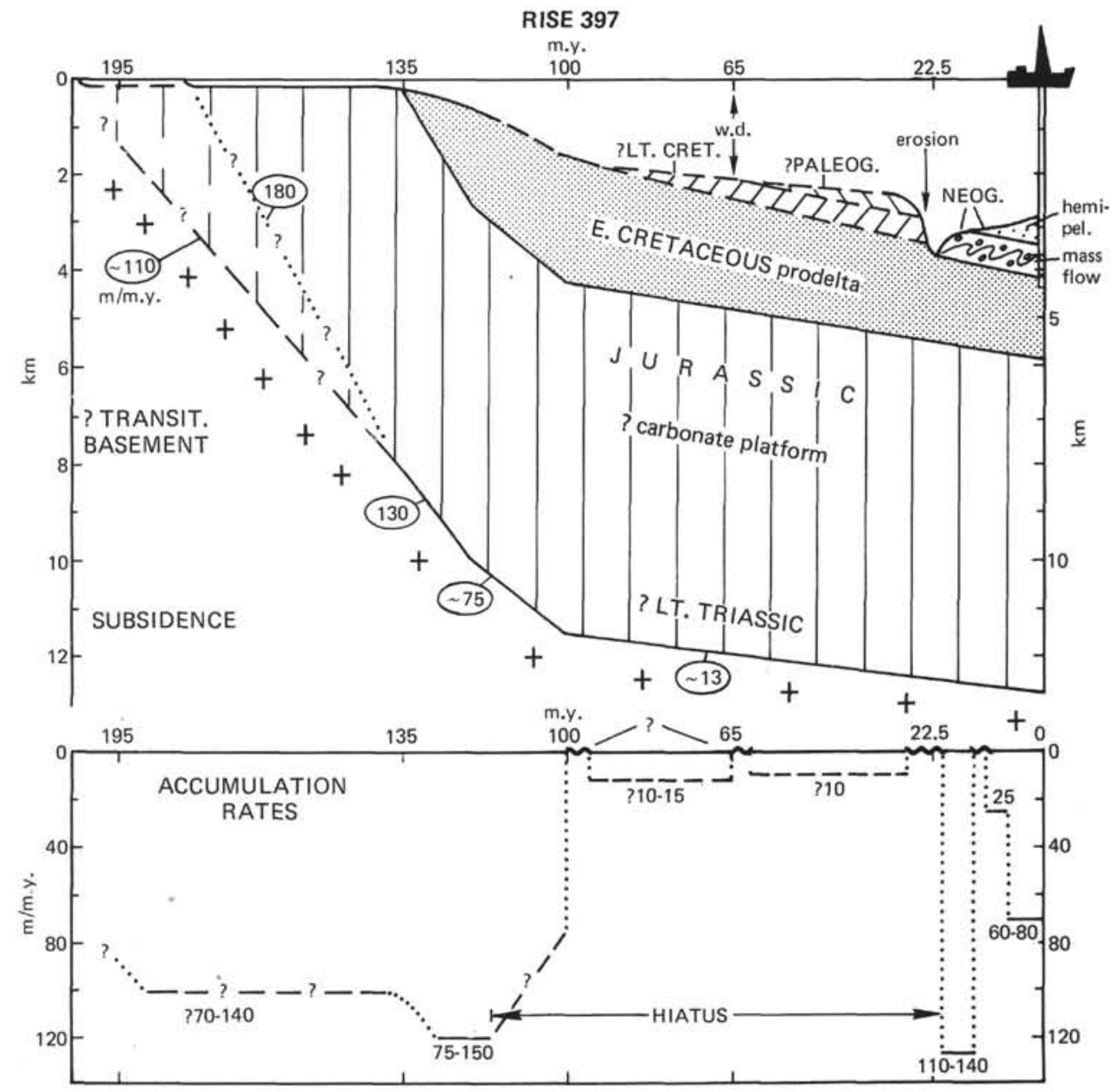

Figure 17. Mesozoic and Cenozoic subsidence history and changes in water depth (W.D.), as well as accumulation rates at and below Site 397 (after von Rad and Einsele, in press). The right-hand margin of the subsidence diagram shows the present thickness and depth below sea level of the different stratigraphic units (see Figures 4 and 5). Rates of subsidence in $\mathrm{m} / \mathrm{m} . \mathrm{y}$. Unburied sediment thicknesses and subsidence rates are corrected for compaction. The reconstructions between 200 and 120 m.y.B.P. are highly speculative (cf. Frontispiece for undrilled Mesozoic record). 
maximum sediment thickness $(4 \mathrm{~km})$ is reached in the inferred "delta front environment" below the present slope. Horizontal to slightly landward dipping strata (landward of the "slope anticline") are offset by antithetic growth faults below the lower slope (see Frontispiece). Seaward, the individual layers thin out toward the distal part of the delta (Hinz, this volume).

Figure 3 shows the vertical facies change from an alluvial plain (lowermost Cretaceous in well CORC 15-1) to a paralic (intertidal to lagoonal: Upper-Lower Cretaceous) to neritic environment (Lower-Upper Cretaceous). This "fining-upward facies sequence" is caused by a transgressive sea and an upward decrease of the terrigenous and increase of the biogenic input (Einsele and von Rad, this volume). The seaward transition from a delta plain or lagoonal facies (CORC 15-1 and Spansah 51A-1; Figure 4) to a prodelta facies can be seen within the Middle-Lower Cretaceous section recovered at Site 397.

For the Hauterivian prodelta mud environment of Site 397, Einsele and von Rad (this volume) estimated a water depth of a few hundred to a maximum of 1000 meters (probably, around $500 \mathrm{~m}$ ). This suggests another point in the subsidence-paleodepth diagram (Figure 17) and indicates that not even the rapid accumulation rates (75 to $150 \mathrm{~m} / \mathrm{m} . \mathrm{y}$.) inferred for the Hauterivian sequence could keep pace with the subsidence of the outer margin. The subsidence rates, calculated for the Lower Cretaceous at Site 397 by comparison with the well-established record of comparable shelf and coast sites, were very rapid $(130 \mathrm{~m} / \mathrm{m} . \mathrm{y}$.; see Figure 17$)$; they decreased to about $75 \mathrm{~m} / \mathrm{m}$.y. toward the end of the Early Cretaceous.

\section{"Middle" Cretaceous to Paleogene History of Subsidence, Sedimentation, and Erosion}

Unfortunately, Upper-Lower Cretaceous to Paleogene sediments were eroded at Site 397 . They are partly preserved landward of the intermediate slope (see Figure $3)$. The thickness of Upper Cretaceous sediments increases between Site 369 (60 m, with hiatuses) and Spansah 51A-1 (915 m; see Figure 4). At Spansah 51A1 , a late Cenomanian transgression produced fully marine varicolored calcilutites and marls which are, in part, dolomitic and cherty. Phosphatic limestones sj ggest upwelling conditions during the latest Cretaceous. Only a few hundred meters of Paleogene sediments were deposited on the slope without any progradation; they are also truncated seaward of the intermediate slope (see Frontispiece).

At Site 369 , only 60 meters of Upper Cretaceous (Coniacian to Maestrichtian) pelagic nannofossil marls and limestones were deposited in an upper-slope environment. On top of an erosional unconformity lie 10 meters of middle Eocene limestones with porcelanites. A surprisingly complete uppermost Eocene to upper Oligocene sequence of hemipelagic siliceous nannofossil ooze is present at this site, whereas the Oligocene sediments were eroded both on the shelf (Spansah 51A-1) and on the upper rise (Site 397).
The Late Cretaceous-Paleogene subsidence history at the present upper rise (Site 397 ) can only indirectly be inferred from comparison with that of Site 369 and Spansah 51A-1. It is necessary to extrapolate the probable paleowater depth at the end of the Early Cretaceous ( 1000 to $2000 \mathrm{~m}$ ) to the present water depth ( 2900 $\mathrm{m})$. It is likely that during the last $100 \mathrm{~m} . \mathrm{y}$. the rates of accumulation were much lower (10 to $15 \mathrm{~m} / \mathrm{m} . \mathrm{y}$.) than in Early Cretaceous times. Sedimentation was probably interrupted by periods of very slow erosion. Therefore, the sea floor continued to deepen, even when subsidence rates decreased to $13 \mathrm{~m} / \mathrm{m}$.y. (Figure 17, von Rad and Einsele, in press). About 90 m.y. after the initial breakup of the Atlantic, source material supply decreases below subsidence rates along most passive continental margins (e.g., Scotian Shelf and Baltimore Canyon Trough; M.S. Steckler, personal communication).

\section{Neogene Subsidence and Paleobathymetry}

During the middle to late Oligocene, geostrophic bottom currents probably cut 1 to $2 \mathrm{~km}$ deep into the lower part of the continental margin at Site 397 (see Figure 17), and eroded all sediments of Paleogene through Hauterivian age. This produced an oversteepened lower continental slope which triggered rapid early Neogene mass sediment flows. The allochthonous sediments subsequently buried this erosional scarp and reduced the water depth to its present value (Arthur and von Rad, this volume). Apparently, the depocenter shifted from its position below the present slope and shelf (Jurassic and Early Cretaceous) to the uppermost rise (Neogene).

\section{Driving Forces of Subsidence at the Cape Bojador Margin}

In determining the causes of subsidence at the Cape Bojador margin, several facts have to be taken into consideration: (1) Typical oceanic crust has only been found west of Gran Canaria (Dash and Boshardt, 1969). Therefore, it is likely that the ill-defined ocean/continent boundary does not underlie the continental slope and uppermost rise (see Figure 16). (2) Continental to transitional basement has a similar depth of about 12 to $15 \mathrm{~km}$ below the present shelf, slope, and rise over a distance of $100 \mathrm{~km}$. This indicates that the Cape Bojador marginal basin subsided uniformly and very rapidly, especially during the first half of its $200-\mathrm{m}$.y. history. The rate of subsidence of the outer Cape Bojador margin is much more rapid than that reported from normal oceanic crust or from the more landward parts of passive continental margins (Sleep, 1971; Ryan, 1976; Watts and Ryan, 1976). Not before Late Cretaceous to Tertiary times did the subsidence rate approach values similar to the ones known from oceanic crust.

According to the empirical exponential relationship between the depth of oceanic basement and age (Sclater et al., 1971; Sclater et al., 1977; Veevers, 1977), unloaded oceanic crust at the continent-ocean boundary can be expected at about $6 \mathrm{~km}$ below sea level, if the ocean basin is 165 to 180 m.y.B.P. However, the 
sediment-loaded continental to transitional basement of the Cape Bojador marginal basin, as well as that below the contingent Baltimore Canyon Trough (Sheridan, 1976; Schlee et al., 1976; Scholle, 1977; Steckler and Watts, in press) and Blake Plateau Basin (Sheridan, 1976 ) is about twice as deep (12 to $14 \mathrm{~km}$ ).

Several mechanisms have been postulated to explain the subsidence of passive continental margins:

1) Thermal-based hypotheses invoke a thermal contraction and subsidence of the cooling lithosphere with a reduction of the thickness of continental crust by subaerial erosion and/or lithospheric extension. Sleep (1971) found an exponentially decreasing subsidence rate with a time constant of about 50 m.y. for the Atlantic margins of North America. For older ocean floor (60 to 80 m.y. after initiation of drifting), the depth initially increases as $\mathrm{t}^{1 / 2}$ (Parsons and Sclater, 1977), the depth below sea level being $d=2500+350 \mathrm{t}^{1 / 2}$ meters $(t$ in m.y.B.P.). They noted that for older sea floor (between 60 and 80 m.y.B.P.), the variation of depth decays exponentially with age toward a constant assymptotic value and explained this consistent flattening of the depth-age curve and reduction of subsidence by heat supply from the mantle to the base of the plate.

2) Falvey (1974) has stressed also that deep crustal metamorphism can increase the density of the crust and, hence, cause progressive subsidence.

3) Stress-based hypotheses postulate shelf subsidence near continental margins by crustal stretching and gravitational outflow of crustal material (Bott, 1971).

4) The gravity-loading hypothesis attributes subsidence to the local depression or flexure of the lithosphere due to the differential weight of the sediment and water load. This effect is especially important, if thick sediment piles are present, such as the deltaic Wealden sequence at the Cape Bojador margin.

Most probably, subsidence of passive continental margins is caused by a combination of "tectonic driving forces" with loading by sediments. For the 180 to 195-m.y.-old margin of the eastern U.S.A., Watts and Ryan (1976) and Steckler and Watts (in press) have distinguished between the load-affected part of subsidence and the remaining portion of subsidence, which must be due to "other driving forces." Because of its similarity with the Sclater curve, this "residual" subsidence is generally attributed to thermal contraction, although the thermal history of a mature continental margin is not strictly comparable with that of an oceanic ridge.

Two of the facts mentioned above for Site 397 make it difficult to apply this combined thermal contraction/ loading model for the Cape Bojador marginal basin: (1) Local loading of an "airy-type crust" by $14 \mathrm{~km}$ of sediments would depress the pre-Jurassic basement by about 7 to $8 \mathrm{~km}$ (Steckler and Watts, in press). The remaining 6 to $7 \mathrm{~km}$ of subsidence are too much to be accounted for by thermal contraction alone (maximum 3 to $4 \mathrm{~km}$ ). (2) In general, there is a poor correlation between total subsidence and sediment load (von Rad and Einsele, in press).

In addition to thermal contraction and isostatic adjustment (sediment loading), it is therefore likely that other mechanisms, such as increase of the thickness or density of the crust (metamorphism), have influenced the vertical movement of the Cape Bojador continental margin, especially during the initial rift and early subsidence history (Jurassic and Early Cretaceous).

For the upper part of the Mesozoic sediments, Lancelot and Seibold (1978) have suggested that the formation of the "slope anticline" on the Cape Bojador margin has been caused by differential sedimentation and subsidence between the coastal Aaiun Basin and the slope and rise. In addition to this process, we assume flexural response ("isostatic rebound") to the accentuated midTertiary erosion of the lower continental slope.

\section{COMPARISON OF THE CAPE BOJADOR CONTINENTAL MARGIN WITH THE NORTHEAST AMERICAN MARGIN DURING JURASSIC AND CRETACEOUS TIMES (M.A.A.)}

\section{Jurassic-Early Cretaceous}

Thick Upper Jurassic to Lower Cretaceous shallowmarine platform carbonates and reefs which might be comparable to the inferred Jurassic carbonate platform of the Cape Bojador margin occur on the western Atlantic margin, e.g., at the Blake Plateau, in the Baltimore Canyon Trough off New Jersey, or at the edge of the Scotian Shelf and Grand Banks (Emery and Uchupi, 1972; Sheridan, 1976; Gradstein et al., 1975; Schlee et al., 1976). These reef barriers have subsided several kilometers since the Middle Cretaceous.

During the Early Cretaceous (Hauterivian, about 125 m.y.B.P.), the southern part of the North Atlantic between western Africa and North America was a narrow $(1500 \mathrm{~km})$, more or less isolated ocean with maximum water depths of about $4 \mathrm{~km}$. There was only little influence from the Tethys and the Pacific (Ryan and Cita, 1977; Sclater et al., 1977). The most striking feature along the margins of this ocean is the out-building of huge Wealden-type deltaic systems prograding over the carbonate platforms and shedding large quantities of clastic sediment onto alluvial plains and adjacent shelf and slope areas (von Rad and Arthur, in press). These delta systems have been best described from the contingent Nova Scotian and Newfoundland shelf basins (Jansa and Wade, 1975). There, the Verril Canyon Member of the Mississagua Formation (Berriasian to Barremian) consists of a thick sequence of prodelta mudstones which are very similar to the Hauterivian of Site 397 (Einsele and von Rad, this volume).

A very similar sequence of more than $1 \mathrm{~km}$ of Upper Jurassic to lowermost Cretaceous nonmarine (terrestrial) to very shallow water clastic sediments of probably deltaic to littoral origin was penetrated in the Baltimore Canyon Trough off New Jersey (COST B-2 well, $150 \mathrm{~m}$ water depth; $4800 \mathrm{~m}$ penetration; Scholle, 1977). The lithofacies and subsidence rates are strikingly similar to those at the shelf well Spansah 51A-1 off Cape Bojador (von Rad and Einsele, in press). Steckler and Watts (in press) have quantitatively calculated the "thermal" subsidence rates of the continental margin off New York near the COST B-2 well by successively removing the 
load of the sediments for different time levels and making corrections for the effects of compaction, water depth, and sea-level changes. Also, the Georges Bank Basin off Cape Cod contains a thick sequence of Lower Cretaceous clastics (Schlee et al., 1977).

\section{Middle Cretaceous}

A major transgression characterized by a more finegrained, oxygen-depleted sedimentation starts with the Aptian to Turonian. Dark colored, organic carbon-rich shales and marls indicate the initiation of basinwide stagnant conditions or an expanded oxygen-minimum layer encroaching part of the shelfs and coastal basins (Fischer and Arthur, 1977; Schlanger and Jenkyns, 1976; Ryan and Cita, 1977). Einsele and Wiedmann (1975) think that the upper Cenomanian to Turonian organic-rich sediments of the Aaiun Tarfaya Basin were caused by regional upwelling after initiation of the trade wind-influenced modern paleocirculation pattern. Similar sediments have been reported from many North Atlantic sites in both eastern and western basins. It is interesting to note the global increase of subsidence rates during the Aptian/Albian period, before the vertical movement slows down at the beginning of the Late Cretaceous. M.S. Steckler (personal communication) thinks that this global increase in subsidence might be due to an eustatic rise in sea level. This accelerated subsidence was observed in the Moroccan coastal basins (Wiedmann et al., 1978), on the outer eastern Canadian shelf (Gradstein et al., 1975), and on the continental shelf between Florida and New Jersey (Whitten, 1976).

\section{Late Cretaceous to Early Paleocene}

The Upper Cretaceous and Paleogene sedimentary record along the Cape Bojador continental margin shows primarily a pelagic influence with nannofossil marls and limestones as the major sediment type. Siliceous microfossils and chert occur in several intervals, primarily in the Paleocene-Eocene, but also the Upper Cretaceous (Figure 3). The Eocene siliceous level is wellknown and widespread in the North Atlantic (e.g., Horizon A). Sedimentation rates are generally low, less than $20 \mathrm{~m} / \mathrm{m}$.y. at most sites in a transect from slope to abyssal plain (Figure 4) during the Late CretaceousPaleogene. Sedimentation rates are also relatively low in the coastal Aaiun Basin. Whereas Early Cretaceous sedimentation rates had been as high as $160 \mathrm{~m} / \mathrm{m}$.y. during the buildup of a large deltaic complex in the Aaiun Basin (Jreibichat Fm., see Figure 4), rates gradually declined to 30 to $45 \mathrm{~m} / \mathrm{m}$.y. in the Late CretaceousPaleocene (Lebtaina Fm., Samlat Fm.) during deposition of organic-rich marine limestones and shales. Thus, regional sedimentation reflects a decline in the influence of terrigenous sources on deep-sea sedimentation, at least partly due to a decline in margin subsidence rates and to a general transgressive episode which flooded coastal basins (Einsele and Wiedmann, 1975) beginning about the Cenomanian. This phase appears to be an Atlantic-wide phenomena. In the western Atlantic basin, Upper Cretaceous sediments at most sites are primarily slowly deposited zeolitic red or multicolored claystone (e.g., Jansa et al., 1978, for review). The deep ocean was apparently well oxygenated in contrast to Early Cretaceous conditions and the CCD was high (Tucholke, Vogt, et al., 1979). These conditions probably reflect a major change in global climates and ocean circulation during the Late Cretaceous (Fischer and Arthur, 1977).

Hiatuses are common in deep-sea sites along the northwestern African margin during the CenomanianTuronian, late Maestrichtian-early Paleocene, and late Eocene-Oligocene. These hiatuses seem concentrated within pronounced sea-level regression intervals. To some extent, they may be due to the influence of intensified bottom-current activity during climatic cooling episodes associated with sea-level changes. The origin of such hiatuses, however, presently is not well known although they are very widespread (e.g., Rona, 1973; Moore and Heath, 1977; Fischer and Arthur, 1977).

\section{Late Paleogene to Neogene}

The evolution of the Cape Bojador continental margin apparently diverses from that of most of the passive margin of eastern North America during the Oligocene and through the Neogene. Two major events occurred in the Cape Bojador region which profoundly influenced local sedimentation: the first was the erosion and back-cutting of the upper rise-lower slope region, possibly by a combination of geostrophic bottom currents and slumping during at least the late Eocene through late Oligocene; the second was the upbuilding and beginning of the subaerial volcanic stage of the Canary Island archipelago probably during the middle Miocene. Thus, it appears that major canyon cutting, bottom current activity, and downslope sediment redeposition caused the partial retreat of this part of the northwestern African passive margin and the shift of the depocenter to the uppermost rise. This phase ended in the early-late Miocene when a thick hemipelagic drape was deposited under upwelling conditions. Much of the remainder of North Atlantic passive margins in more humid climatic zones have less complicated progradational histories. Canary Island volcanism is recorded in the form of middle Miocene volcaniclastic debris flows on the upper rise (Site 397) and by fairly numerous rhyolitic ash layers in Sites 369 and 397. This is the main sedimentary imprint of regional volcanotectonic activity. Little if any direct tectonic influence was noted from the Atlas Mountains to the north which were folded and uplifted during mid-Tertiary times.

During the low sea-level stands of the late Neogene, surprisingly little terrigenous material was incorporated in sediment along the Cape Bojador margin. DSDP Sites 369 on the continental slope and 397 on the upper rise are conspicuously lacking in terrigenous detritus. Even so, sedimentation rates on this margin were fairly high during the late Neogene, primarily due to high carbonate (and to some extent, siliceous) productivity under upwelling conditions (see Cita and Ryan; DiesterHaass; both, this volume). Rates ranged from about 30 
$\mathrm{m} / \mathrm{m}$.y. on the slope to 50 to $85 \mathrm{~m} / \mathrm{m} . \mathrm{y}$. on the upper rise; rates of deposition of Neogene nannofossil ooze decreased away from the margin to $<20 \mathrm{~m} / \mathrm{m}$.y. Climatic fluctuations are evident in sediment of late Neogene-Quaternary age; these are marked by variations in reworking of shallow-water biogenic detritus and glauconite, in carbonate preservation, stable isotopes in abundance of biogenic siliceous components, and in components evidencing alternating humid/arid conditions on the adjacent continent such as clay minerals and stained quartz (see paleoenvironment chapters, this volume). The high sedimentation rates, low terrigenous influx, and lack of sediment redeposition along this part of the margin during the late Miocene through Quaternary make this a unique area (e.g., DSDP Site 397) for study of climatic fluctuations and oceanographic events. In this respect, it differs from other parts of the northwestern African margin which have been dominated by high input of terrigenous sediment and large-scale sediment redeposition during most of the late Neogene-Quaternary (see, for review: Uchupi et al., 1976; Embley, 1976; Jacobi, 1976; Lancelot, Seibold et al., 1978). The Cape Bojador region also seems to have been little affected by bottom-current activity during the late Neogene, whereas the sedimentation along the continental margin of eastern North America has been profoundly influenced by redeposition and reworking by contour currents (e.g., Heezen et al., 1966; Schneider et al., 1967).

\section{ACKNOWLEDGMENTS}

We would like to acknowledge the shipboard scientists of Leg 47A for their input in the form of data and discussions, without which we would have been unable to attempt this synthesis. W.B.F. Ryan, M. B. Cita, F. Wind, P. Čepek, G. Lutze, and J. Whelan have been especially helpful. We thank $\mathrm{O}$. Weser for allowing us to modify a figure (Figure 15) from his unpublished report on hydrocarbon occurrences, K. Hinz (BGR, Hannover) and CONOCO (Norway) for making it possible to use CONOCO's Spansah data, and G. Wissmann (BGR, Hannover) for allowing us to use Meteor seismic Profiles M-46 through M-37 and for his interpretation of that line. We also acknowledge the advice and data given us by $\mathrm{H}$. U. Schmincke (Bochum) with regard to the volcanic history of the Canary Islands. E. L. Winterer (SIO), H. U. Schmincke (Bochum), G. Einsele (Tübingen), M. S. Steckler (L-DGO), W. B. F. Ryan (L-DGO), G. Wissmann (BGR, Hannover), D. Kelwer (BGR, Hannover), and D. Kempter (BGR, Hannover) reviewed parts of the manuscript.

\section{REFERENCES}

Abdel Monem, A., Watkins, N.D., and Gast, P.W., 1974. Potassium-argon ages, volcanic stratigraphy, and geomagnetic polarity history of the Canary Islands: Lancarote, Fuerteventura, Gran Canaria, and La Gomera, Am. J. Sci., v. 271 , p. $490-521$.

Allen, P., 1959. The Wealden environment, Anglo Paris Basin, Phil. Trans. Roy. Soc. London, ser. B, v. 242, p. 283-346.

AUXINI (Departamento de Investigaciones Petroliferas de AUXINI), 1969. Correlacion estratigraphica de los sondeos perforados en el Sahara Español, Bol. Geol. Minero, Madrid, v. 83 , p. $235-251$.
Beck, R.H. and Lehner, P., 1974. Oceans, new frontier in exploration, Am. Assoc. Petrol. Geol. Bull., v. 58, p. 376-395.

Berger, W.H., 1973. Cenozoic sedimentation in the eastern tropical Pacific, Geol. Soc. Am. Bull., v. 84, p. 1941-1954.

Berger, W.H. and Soutar, A., 1970. Preservation of plankton shells in an anaerobic basin off California, Geol. Soc. Am. Bull., v. 81, p. 275-282.

Berger, W.H. and von Rad, U., 1972. Cretaceous and Cenozoic sediments from the Atlantic Ocean. In Hayes, D.E., Pimm, A.C., et al., Initial Reports of the Deep Sea Drilling Project, v. 14: Washington (U.S. Government Printing Office), p. 787-954.

Berggren, W.A., 1973. The Pliocene time-scale: calibration of planktonic foraminiferal and calcareous nannoplankton zones, Nature, v. 243, p. 391-397.

Berggren, W.A. and van Couvering, J.A., 1974. The late Neogene: Dev. Palaeont. Strat. 2: New York (Elsevier).

Bernoulli, D., Fuster, J.M., Hottinger, L., and Renz, O., in press. Mesozoic and early Tertiary sediments and faunas from Fuerteventura (Canary Islands).

Bott, M.H.P., 1971. Evolution of young continental margins and formation of shelf basins, Tectonophysics, v. 11, p. 319-327.

Bouma, A.H. and Hollister, C.D., 1973. Deep ocean basin sedimentation: SEPM Pacific Sect. Short Course, Turbidites and deep-water sedimentation, p. 79-118.

Carter, R.M., 1975. A discussion and classification of subaqueous mass-transport with particular application to grain-flow, slurry-flow, and fluxoturbidites, Earth Sci. Rev., v. 11 , p. $145-177$.

Chester, R., Elderfield, H., Griffin, J.J., Johnson, L.R., and Padgham, R.C., 1972. Eolian dust along the eastern margins of the Atlantic Ocean, Mar. Geol., v. 13, p. 91-106.

Cita, M., 1973. Pliocene biostratigraphy and chronostratigraphy. In Ryan, W.B.F., Hsü, K.J., et al., Initial Reports of the Deep Sea Drilling Project, v. 13: Washington (U.S. Government Printing Office), p. 1343-1379.

Conrad, G., 1969. L'evolution continentale post-hercynienne du Sahara algerienne, Ser. Geol., v. 10, C.N.R.S., p. 1-527.

Connan, T., 1974. Time-temperature relation in oil genesis, Am. Assoc. Petrol. Geol. Bull., v. 58, p. 2516.

CONOCO, 1969. Spansah 51A-1, offshore Spanish Sahara: Final Report by Continental Oil Company of Spain, Spanish Gulf Oil Company, Compania Espanol de Petroleas S.A. Exploration Department, unpublished report and logs.

Dash, B.P. and Bosshard, E., 1969. Seismic and gravity investigations around the western Canary Islands, EPSL, v. 7, p. 169-177.

Davies, T.A., Weser, O.E., Luyendyk, B.P., and Kidd, R.B., 1975. Unconformities in the sediments of the Indian Ocean, Nature, v. 253, p. 15-16.

Diester-Haass, L., 1976. Sediments as indicators of upwelling: Third Int. Symp. Upwelling Ecosystems Kiel, Proc.:Heidelberg (Springer-Verlag).

1977. Radiolarian/planktonic foraminiferal ratios in a coastal upwelling region, J. Foram. Res., v. 7, p. 26-33. 1978. Influence of carbonate dissolution, climate, sea-level changes and volcanism on Neogene sediments off W. Africa (Leg 41). In Lancelot, Y., Seibold, E., et al., Initial Reports of the Deep Sea Drilling Project, v. 41: Washington (U.S. Government Printing Office), p. 1033-1048.

Dillon, W.P. and Sougy, J.M.A., 1974. Geology of West Africa and Canary and Cape Verde Islands. In Nairn, 
A.E.M. and Stehli, F.G. (Eds.), The ocean basins and margins, the North Atlantic: New York (Plenum Press), v. 2, p. 315-390.

Dzulonski, S., Ksiazkiewicz, M., and Kuenen, P.H., 1959. Turbidites in flysch of the Polish Carpathian Mountains, Geol. Soc. Am. Bull., v. 70, p. 1089-1118.

Einsele, G. and Wiedmann, J., 1975. Faunal and sedimentological evidence for upwelling in the Upper Cretaceous coastal basin of Tarfaya, Morocco, Ninth Internat. Congr. Sedimentol., Nice, v. 1, p. 67-72.

Embley, R.W., 1976. New evidence for occurrence of debris flow deposits in the deep sea, Geology, v. 4, p. 371-374.

Emery, K.O. and Uchupi, E., 1972. Western North Atlantic Ocean: topography rocks, structure, water, life, and sediments, Am. Assoc. Petrol. Geol. Mem. 17, p. 1-532.

Falvey, D.A., 1974. The development of continental margins in plate tectonic theory, Austral. Pet. Explor. Assoc. J., v. 14 , p. $95-106$.

Fischer, A.G. and Arthur, M.A., 1977. Secular variations in the pelagic realm. In Cook, H.E. and Enos, P. (Eds.), Deep water carbonate environments: Soc. Econ. Paleontol. Mineral., Spec. Publ. 25, p. 19-50.

Francheteau, J., 1970. Paleomagnetism and plate tectonics: SIO Reference $70-30$, p. 1-345.

Freed, W.K. and Watkins, N.D., 1975. Volcanic eruptions: contribution to magnetism in deep-sea sediments downwind from the Azores, Science, v. 188, p. 1203-1205.

Gartner, S., 1977. Nannofossils and biostratigraphy: an overview, Earth Sci. Rev., v. 13, p. 227-250.

Gradstein, F.M., Williams, G.L., Jenkins, W.A.M., and Ascoli, P., 1975. Mesozoic and Cenozoic stratigraphy of the Atlantic continental margin, Eastern Canada: In Canad. Continental Margins Offshore Petrol. Symp., St. John's Newfoundland, Calgary (Alberta), 1974, Canad. Soc. Petrol. Geol., p. 103-131.

Grunau, H.R., Lehner, P., Cleintuar, M.R., Allenbach, P., and Bakker, G., 1975. New radiometric ages and seismic data from Fuerteventura (Canary Islands), Maio (Cape Verde Islands), and Sao Tome (Gulf of Guinea). In Borradaile, G.J. et al. (Eds.), Progress in geodynamics: Amsterdam (North Holland Publ. Comp.), p. 90-118.

Hampton, M.A., 1972. The role of subaqueous debris flow in generating turbidity currents, J. Sediment Petrol., v. 42, p. 775-793.

Hays, D.E. and Rabinowitz, P.D., 1975. Mesozoic magnetic lineations and the magnetic quiet zone off Northwest Africa, Earth Planet. Sci. Lett., v. 28, p. 105-115.

Hays, D.E., Frakes, L.A., et al., 1975. Initial Reports of the Deep Sea Drilling Project, v. 28: Washington (U.S. Government Printing Office).

Hedberg, H.D., 1970. Continental margins from viewpoint of the petroleum geologist, Am. Assoc. Petrol. Geol. Bull., v. 54 , p. 3 .

Herman, B.M., Langseth, M.G., and Hobart, M.A., 1977. Heat flow in the oceanic crust bounding West Africa, Tectonophysics, v. 41, p. 61-77.

Hinz, K., Seibold, E., and Wissmann, G., 1974. Continental slope anticline and unconformities off West Africa, 'Meteor'” Forsch. Ergebn., Reike C, no. 17, p. 67-73.

Hollister, C., Ewing, J., et al., 1972. Initial Reports of the Deep Sea Drilling Project, v. 11: Washington (U.S. Government Printing Office).

Hollister, C.D. and Heezen, B.C., 1972. Geologic effects of ocean-bottom currents: western North Atlantic. In Gordon and Breach (Eds.), Studies in physical oceanography: v. 2, p. 37-66.

Hood, A., Gutjahr, C.C.M., and Heacock, R.C., 1975. Organic metamorphism and the generation of petroleum, Am. Assoc. Petrol. Geol. Bull., v. 59, p. 986-996.

Jacobi, R.D., 1976. Sediment slides on the northwestern continental margin of Africa, Mar. Geol., v. 22, p. 157-173.

Jacobi, R.D., Rabinowitz, P.D., and Embley, R.W., 1975. Sediment waves on the Moroccan Continental Rise, Mar. Geol., v. 19, p. M61-67.

Jansa, L.F. and Wade, J.A., 1975. Geology of the continental margin off Nova Scotia and Newfoundland: Offshore Geology of Eastern Canada, Geol. Survey Canada, Paper 74-30, v. 2.

Jansa, L., Gardner, J.V., and Dean, W.E., 1978. Mesozoic sequences of the Central North Atlantic. In Lancelot, Y., Seibold, E., et al., Initial Reports of the Deep Sea Drilling Project, v. 41: Washington (U.S. Government Printing Office), p. 991-1032.

Johnson, D.A., 1972. Ocean floor erosion in the equatorial Pacific, Geol. Soc. Am. Bull., v. 83, p. 3121-3144.

Kelling, G. and Stanley, D.J., 1976. Sedimentation in canyon, slope, and base-of-slope environments. In Stanley, D.J. and Swift, D.J.P. (Eds.), Marine sediment transport and environmental management: New York (J. Wiley \& Sons, Inc.), p. 379-435.

Kennedy, W.Q., 1965. The influence of basement structure on the evolution of the coastal (Mesozoic and Tertiary) basins of Africa, in salt basins around Africa, London Inst. Petrol., p. 7-16.

Kennett, J.P., 1977. Cenozoic evolution of Antarctic glaciation, the circum-Antarctic Ocean, and their impact on global paleo-oceanography, J. Geophys. Res., v. 82, p. 3843-3860.

Kennett, J.P., Burns, R.E., Andrews, J.E., Churkin, M., Davies, T.A., Dumitrică, P., Edwards, A.R., Galehouse, J.S., Packham, G.H., and van der Lingen, G.J., 1972. Australian-Antarctic continental drift, paleocirculation changes and Oligocene deep-sea erosion, Nature, Phys. Sci., v. 239, p. 51-53.

Kennett, J.P., Houtz, R.E., et al., 1975. Initial Reports of the Deep Sea Drilling Project, v. 29: Washington (U.S. Government Printing Office).

Kinsman, D.J.J., 1975. Rift valley basins and sedimentary history of trailing continental margins. In Fischer, A.G. and Judson, S. (Eds.), Petroleum and global tectonics: p. 83-126.

Kiper, M., 1977. Sedimente und ihre Umwelt im Senegaldelta, Unpubl. Master Thesis, Univ. Kiel.

Koopmann, B., Lees, A., Piessens, P., and Sarnthein, M., in press. Skeletal carbonates and wind derived silty marls off the Saharan coast, Baie du Levrier, Arguin Platform, Mauritania, “Meteor'” Forsch. Rieke C.

Lancelot, Y., Hathaway, J.C., and Hollister, C.D., 1972. Lithology of sediments from the western North Atlantic, Leg 11, DSDP. In Hollister, C.D., Ewing, J.I., et al., Initial Reports of the Deep Sea Drilling Project, v. 11: Washington (U.S. Government Printing Office), p. 901-949.

Lancelot, J. and Seibold, E., 1978. The evolution of the central northeastern Atlantic-Summary of results of DSDP Leg 41. In Lancelot, Y., Seibold, E., et al., Initial Reports of the Deep Sea Drilling Project, v. 41: Washington (U.S. Government Printing Office), p. 1215-1245. 
Lancelot, Y., Seibold, E., et al., 1978. Initial Reports of the Deep Sea Drilling Project, v. 41: Washington (U.S. Government Printing Office).

Lancelot, Y., Winterer, E.L., and the Shipboard Scientific Party of DSDP Leg 50, 1977. In the Atlantic: documenting early rifting, Geotimes, v. 22, p. 24-27.

Lange, H., 1975. Kerkunft und Verteilung von Oberflachensedimenten des westafrikanischen Schelfs und Kontinentalhamp, "Meteor" Forsch.-Ergebn., Rieke $C$, no. 22, p. 21-84.

Lees, A., 1975. Possible influence of salinity and temperature on modern shelf carbonate sedimentation, Mar. Geol., v. 19 , p. $159-198$.

Lehner, P. and DeRuiter, P.A.D., 1977. Structural history of the Atlantic margin off Africa, Am. Assoc. Petrol. Geol. Bull., v. 61, p. 961-981.

Le Pichon, X., Sibuet, J.C., and Francheteau, J., 1977. The fit of the continents around the North Atlantic Ocean, Tectonophysics, v. 38, p. 169-209.

Lietz, J. and Schmincke, H.U., 1975. Miocene-Pliocene sea level changes and volcanic phases on Gran Canaria (Canary Islands) in the light of new K-Ar ages, Paleogeogr. Paleoclimatol., Paleoecol., v. 18, p. 213-239.

MacDonald, G.A. and Abbott, A.T., 1970. Volcanoes in the sea. The geology of Hawaii: Honolulu (Univ. Press of Hawaii).

Manabe, S. and Hahn, D., 1977. Simulation of the tropical climate of an ice-age, J. Geophys. Res., v. 82, p. 3889-3909.

Martini, E., 1976. Cretaceous to recent calcareous nannoplankton from the Central Pacific Ocean (DSDP Leg 33). In Schlanger, S.O., Jackson, E.D., et al., Initial Reports of the Deep Sea Drilling Project, v. 33: Washington (U.S. Government Printing Office), p. 383-424.

McCoy, F.W. and Zimmerman, H.B., 1977. A history of sediment lithofacies in the South Atlantic Ocean. In Supko, P.R., Perch-Nielsen, K., et al., Initial Reports of the Deep Sea Drilling Project, v. 39: Washington (U.S. Government Printing Office), p. 1047-1080.

McDougall, I. and Schmincke, H.U., 1977. Geochronology of Gran Canaria Canary Islands: age of shield building volcanism and other magmatic phases, Bull. Volcanol., v. 40 , p. $1-21$.

McMaster, R.L. and LaChance, T.P., 1968. Seismic reflectivity studies on Northwestern African continental shelf, Strait of Gibraltar to Mauritania, Am. Assoc. Petrol. Geol. Bull., v. 52, p. 2387-2396.

Michel, P., 1973. Les bassins des fleuves Senegal et Gambie. Etude geomorphologique, Mem. ORSTOM, no. 63, p. 1-752.

Middleton, G.V. and Hampton, M.A., 1973. Sediment gravity flows: mechanics of flow and deposition, Soc. Econ. Paleontol. Mineral. (Pacific Section) Short Course Lecture Notes. Turbidites and deep-water sedimentation, p. 1-38.

Moore, T.C. and Heath, G.R., 1977. Survival of deep sea sedimentary sections, Earth Planet. Sci. Lett., v. 37, p. 71-80.

Mutti, E. and Ricci-Lucchi, F., 1972. Le torbiditi dell' Appenino settentrionale: introduzione all' analisi di facies, Mem. Soc. Geol. Italiana, v. 11, p. 161-199.

Nelson, C.H. and Kulm, V., 1973. Submarine fans and channels. In Middleton, G.V. and Bouma, A.H. (Eds.), Turbidites and deep water sedimentation: Anaheim (SEPM Pacific Section), p. 39-78.

Parsons, B. and Sclater, J.G., 1977. An analysis of the variation of ocean floor heat flow and bathymetry with age, J. Geophys. Res., v. 82 , p. 803-827.
Pitman, W.C., III, in press. The relationship between eustatic changes of sea level and stratigraphic sequences, Geol. Soc. Am. Bull.

Querol, R., 1966. Regional geology of the Spanish Sahara. In Reyre, D. (Ed.), Sedimentary basins of the African Coast: Paris (Assoc. African Geol. Surv.), p. 27-39.

Ratschiller, L.K., 1970. Lithostratigraphy of the Northern Spanish Sahara, Mem. Museo Tridentino Sci. Nat., v. 18, p. 9-84.

Renz, O., Imlay, R., Lancelot, Y., and Ryan, W.B.F., 1975. Ammonite-rich Oxfordian limestones from the base of the continental slope off Northwest Africa, Eclog. Geol. Helv., v. 68 , p. $431-448$.

Ricci-Lucchi, F., 1975. Miocene paleogeography and basin analysis in the Periadriatic Appennines. In Squyres, C. (Ed.), Geology of Italy: Tripoli (Petroleum Exporation Soc. of Lybia), p. 5-111.

Roeser, H.A., Hinz, K., and Plaumann, S., 1971. Continental margin structure in the Canaries. In Delany, F.M. (Ed.), The geology of the East Atlantic continental margin: ICSU/SCOR working Party 31, Symposium, Cambridge (1970), NERC/IGS, p. 31-40.

Rognon, P., 1976. Essai d'interpretation des variations climatiques au Sahara depuis 40000 ans, Rev. Geogr. Phys. Geol. Dyn., v. 18, p. 251-282.

Rona, P.A., 1973. Worldwide unconformities in marine sediments related to eustatic changes of sea level, Nature, Phys. Sci., v. 244 , p. $25-26$.

Rothe, P., 1968. Mesozoische Flysch-Ablagerungen auf der Kanareninsel Fuerteventura, Geol. Rundschau, v. 58, p. 314-322.

Rothe, P. and Koch, R., 1978. Miocene volcanic glass from DSDP Sites 369, 368 and 370. In Lancelot, Y., Seibold, E., et al., Initial Reports of the Deep Sea Drilling Project, v. 41: Washington (U.S. Government Printing Office), p. 1061-1064.

Rust, U. and Weinecke, F., 1973. Bathymetrische und geomorphologische Bearbeitung von submarinen "Einschnitten" im Seegebiet vor Westafrika. Ein methodischer Versuch, Munchner Geogr. Abh., Geogr. Inst. Univ. Munchen, v. 9, p. 53-67.

Ryan, W.B.F., 1976. Quantitative evaluation of the depth of the western Mediterranean before, during and after the Late Miocene salinity crisis, Sedimentology, v. 23, p. 791-813.

Ryan, W.B.F. and Cita, M.B., 1977. Ignorance concerning episodes of ocean-wide stagnation, Mar. Geol., v. 23, p. 197-215.

Ryan, W.B.F., Cita, M.B., Dreyfus-Rawson, M., Burckle, L.H., and Saito, T., 1974. A paleomagnetic assignment of Neogene stage boundaries and the development of isochronous datum planes between the Mediterranean, the Pacific and Indian oceans in order to investigate the response of the world ocean to the Mediterranean "salinity crisis," Riv. Ital. Paleontol., v. 80, p. 631-688.

Sarnthein, M., 1971. Oberflachensedimente im Persischen Golf und Golf von Oman. II. Quantitative Komponentenanalyse der Grobfraktion, "Meteor"' Forsch.-Ergebn., v. 5, p. 1-113.

, 1978a. Neogene turbidites off NW Africa: Composition and source environment. In Lancelot, Y., Siebold, E., et al., Initial Reports of the Deep Sea Drilling Project, Supplement to Volumes $38,39,40$, and 41: Washington (U.S. Government Printing Office).

1978b. Sand deserts during glacial maximum and climatic optimum, Nature, v. 271, p. 5648. 
Sarnthein, M. and Diester-Haass, L., 1977. Eolian-sand turbidites, J. Sediment. Petrol., v. 47, p. 868-890.

Savin, S.M., Douglas, R.G., and Stehli, F.G., 1975. Tertiary marine paleotemperatures, Geol. Soc. Am. Bull., v. 86, p. 1499-1514.

Schlanger, S.O. and Jenkyns, H.C., 1976. Cretaceous oceanic anoxic sediments: causes and consequences, Geologie en Mijnbouw, v. 55, p. 179-184.

Schlee, J., Behrendt, J.C., Grow, J.A., Robb, J.M., Mattick, R.E., Taylor, P.T., and Lawson, B.J., 1976. Regional geologic framework off Northeastern United States, $\mathrm{Am}$. Assoc. Petrol. Geol. Bull., v. 60, p. 926-951.

Schmincke, H.U., 1976. The geology of the Canary Islands. In Kunkel, G. (Ed.), Biogeography and ecology in the Canary Islands: The Hague (W. Junk), p. 67-184.

Schmincke, H.U. and Flower, M.J.F., 1974. Magmenevolution auf atlantischen Vulkaninseln, Naturwissenschaften, v. 61, p. $288-297$.

Scholle, P.A. (Ed.), 1977. Geological studies on the COST No. B-2 well, U.S. Mid-Atlantic outer continental shelf, U.S. Geol. Survey Circ. 750, p. 1-71.

Sclater, J.G., Anderson, R.N., and Bell, M.L., 1971. Elevation of ridges and evolution of the central eastern Pacific, J. Geophys, Res., v. 76, p. 7888-7915.

Sclater, J.G., Hellinger, S., and Tapscott, C., 1977. The paleobathymetry of the Atlantic Ocean from the Jurassic to the present, J. Geol., v. 85 , p. 509-552.

Seibold, E. and Hinz, K., 1974. Continental slope construction and destruction, West Africa. In Burk, C.A. and Drake, C.L. (Eds.), The geology of continental margins: New York, Heidelberg, Berlin (Springer), p. 179-196.

Shackleton, N.J. and Kennett, J.P., 1974. Paleotemperature history of the Cenozoic and the initiation of Antarctic glaciation: Oxygen and carbon isotope analysis in DSDP Sites 277, 279, and 281. In Kennett, J.P., Houtz, R.E., et al., Initial Reports of the Deep Sea Drilling Project, v. 29: Washington (U.S. Government Printing Office), p. 743-755.

Shepard, F.P. and Dill, R.F., 1966. Submarine canyons and other sea valleys: Chicago (Rand McNally).

Sheridan, R.E., 1976. Sedimentary basins of the Atlantic margin of North America, Tectonophysics, v. 36, p. 113-132.

Sleep, N.H., 1971. Thermal effects of the formation of Atlantic continental margins by continental break-up, Geophys. J. Roy. Astron. Soc., v. 24, p. 325-350.

Stanley, D.J., 1970. Flyschoid sedimentation on the outer Atlantic margin off northeast North America. In Lajoie, J. (Ed.), Flysch sedimentology in North America: Geol. Assoc. Canada, Spec. Paper 7, p. 179-210.

1975. Submarine canyon and slope sedimentation (Gres d' Annot) in the French Maritime Alps, Ninth Internat. Congr. Sediment., Nice, Guidebook.

Stanley, D.J. and Unrug, R., 1972. Submarine channel deposits, fluxoturbidites and other indicators of base-ofslope environments in modern and ancient marine basins. In Rigby, J.K. and Hamblin, W.K. (Eds.), Soc. Econ. Paleontol. Mineral., Spec. Publ. 16, p. 287-340.

Stauffer, P.M., 1968. Grain flow deposits and their implications, Santa Ynez Mountains, California, J. Sediment. Petrol., v. 37, p. 487-508.

Steckler, M.S. and Watts, A.B., in press. Subsidence of the Atlantic-type continental margin off New York, Earth Planet. Sci. Lett.

Summerhayes, C.P., Nutter, A.H., and Tooms, J.S., 1971. Geological structure and development of the continental margin of northwest Africa, Mar. Geol., v. 11, p. 1-27.
Summerhayes, C.P., Milliman, J.D., Briggs, S.R., Bee, A.G. and Hogan, C., 1976. Northwest African shelf sediments: influence of climate and sedimentary processes, J. Geol., v. 84 , p. $277-300$.

Supko, P., Perch-Nielsen, K., et al., 1977. Initial Reports of the Deep Sea Drilling Project, v. 39: Washington (U.S. Government Printing Office).

Thiede, J. and van Andel, T.H., 1977. The paleoenvironment of anaerobic sediments in the Late Mesozoic South Atlantic Ocean, Earth Planet. Sci. Lett., v. 33, p. 301-309.

Thompson, T.L., 1976. Plate tectonics in oil and gas exploration of continental margins, Am. Assoc. Petrol. Geol. Bull., v. 60 , p. 1463 .

Tissot, B., 1978. Organic matter in Cretaceous sediments of the North Atlantic: contribution to sedimentology and paleogeography, Abstracts of the Second Maurice Ewing Symposium, March 19-25, 1978, Arden House, New York, p. $39-40$.

Tooms, J.S. and Summerhayes, C.P., 1968. Phosphatic rocks from the northwest African continental shelf, Nature, v. 218, p. $1241-1242$.

Tooms, J.S., Summerhayes, C.P., and McMaster, R.L., 1971. Marine geological studies on the northwest African margin: Rabat-Dakar. In Delany, F.M. (Ed.), The geology of the East Atlantic continental margin: ICSU/SCOR working party, 31 symp., Cambridge, 1970, Rept. 70/16, London.

Tucholke, B., Vogt, P., et al., 1979. Initial Reports of the Deep Sea Drilling Project, v. 43: Washington (U.S. Government Printing Office).

Uchupi, E., Emergy, K.O., Bowin, C.O., and Phillips, J.D., 1976. Continental margin off Western Africa: Senegal to Portugal, Am. Assoc. Petrol. Geol. Bull., v. 60, p. 809-878.

Unrug, R., 1963. Istebna Beds - a fluxoturbidite formation in the Carpathian flysch, Am. Soc. Geol. Polozne, v. 33, p. 49-92.

Vail, P.R., Mitchum, R.J., Jr., and Thompson, S., 1977. Seismic stratigraphy and global changes of sea-level, Part 3: Relative changes of sea level from coastal onlap, $\mathrm{Am}$. Assoc. Petrol. Geol. Mem. 26, p. 63-98.

van Andel, T., 1975. Mesozoic/Cenozoic calcite compensation depth and the global distribution of calcareous sediments, Earth Planet. Sci. Lett., v. 26, p. 187-194.

van Andel, T., Thiede, J., Sclater, J.G., and Hay, W.W., 1978. Depositional history of the South Atlantic Ocean during the last 125 m.y., J. Geol., v. 85, p. 651-698.

Veevers, J.J., 1977. Paleobathymetry of the crest of spreading ridges related to the age of ocean basins, Earth Planet. Sci. Lett., v. 34, p. 100-106.

von Rad, U. and Arthur, M.A., in press. Geodynamic, sedimentary, and volcanic evolution of the northwest African margin (Cape Bojador-Canary Islands): paleoenvironment, slope rejuvenation, and gravitative deposition. In Ryan, W.B.F. and Hay, W. (Eds.), Maurice Ewing Series, Am. Geophys. Union, v. 3.

von Rad, U., Čepek, P., von Stackelberg, U., Wissmann, G., and Zobel, B., 1978. Cretaceous and Tertiary sediments from the Northwest African slope (dredges and cores supplementing DSDP results), Mar. Geol., v. 28.

von Rad, U. and Einsele, G., in press. Mesozoic-Cenozoic subsidence history and paleobathymetry of the Northwest African continental margin (Aaiun Basin to DSDP Site 397), Phil. Trans. Roy. Soc. London.

von Stackelberg, U., von Rad, U., and Zobel, B., 1976. Asymmetric distribution of displaced material in calcareous oozes around Great Meteor Seamount (North Atlantic), "Meteor" Forsch.-Ergebn., Reike C, no. 25, p. 1-46. 
Walker, R.G., 1970. Review of the geometry and facies organization of turbidites and turbidite-bearing basins, Geol. Assoc. Canada Spec. Pap. 7, p. 219-251.

Watts, A.B. and Ryan, W.B.F., 1976. Flexure of the lithosphere and continental margin basins, Tectonophysics, v. 36, p. $25-44$.
Whitten, E.H.T., 1976. Geodynamic significance of spasmodic, Cretaceous, rapid subsidence rates, continental shelf, U.S.A., Tectonophysics, v. 36, p. 133-142.

Wiedmann, J., Butt, A., Dietrich, H.G. and Einsele, G., 1978. Vergleich von Kreide-Kustenprofilen und Tiefseebohrungen (DSDP): Stratigraphic, Fazies und Geodynamik des Kontinentalrandes vor Marokko, Geol. Rundschau, v. 67. 